\title{
Camila Moratore
}

\section{Padrões genético-morfológicos em populações de Culex quinquefasciatus (Diptera: Culicidae)}

\author{
Dissertação apresentada ao \\ Departamento de Parasitologia do \\ Instituto de Ciências Biomédicas da \\ Universidade de São Paulo, para \\ obtenção de Título de Mestre em \\ Ciências.
}

Área de concentração: Biologia da Relação Patógeno-Hospedeiro 


\title{
Camila Moratore
}

\section{Padrões genético-morfológicos em populações de Culex quinquefasciatus (Diptera: Culicidae)}

\author{
Dissertação apresentada ao \\ Departamento de Parasitologia do \\ Instituto de Ciências Biomédicas da \\ Universidade de São Paulo, para \\ obtenção de Título de Mestre em \\ Ciências.
}

Área de concentração: Biologia da Relação Patógeno-Hospedeiro

Orientador: $\operatorname{Prof}^{0} \operatorname{Dr}^{0}$ Lincoln Suesdek Rocha 
DADOS DE CATALOGAÇÃO NA PUBLICAÇÃO (CIP)

Serviço de Biblioteca e Informação Biomédica do Instituto de Ciências Biomédicas da Universidade de São Paulo

(C) reprodução total

Moratore, Camila.

Padrões genético-morfológicos em populações de Culex quinquefasciatus (Diptera: Culicidade) / Camila Moratore. -- São Paulo, 2009.

Orientador: Lincoln Suesdek Rocha.

Dissertação (Mestrado) - Universidade de São Paulo. Instituto de Ciências Biomédicas. Departamento de Parasitologia. Área de concentração: Biologia da Relação Patógeno-Hospedeiro. Linha de pesquisa: Culicídeos de interesse médico.

Versão do título para o inglês: Genetic and morphological patterns in populations of Culex quinquefasciatus (Diptera:Culicidade) .

Descritores: 1. Culex 2. Insetos vetores 3. Morfometria 4. Evolução 5. Microscopia eletrônica I. Rocha, Lincoln Suesdek II. Universidade de São Paulo. Instituto de Ciências Biomédicas. Programa de Pós-Graduação em Biologia da Relação Patógeno-Hospedeiro III. Título. 
UNIVERSIDADE DE SÃO PAULO

INSTITUTO DE CIÊNCIAS BIOMÉDICAS

Candidato(a): Camila Moratore.

Título da Dissertação: $\quad$ Padrões genético-morfológicos em populações de Culex quinquefasciatus (Diptera: Culicidade).

Orientador(a): $\quad$ Lincoln Suesdek Rocha.

A Comissão Julgadora dos trabalhos de Defesa da Dissertação de Mestrado, em sessão pública realizada a ..................................,
( ) Aprovado(a)
( ) Reprovado(a)

Examinador(a): Assinatura:

Nome:

Instituição:

Examinador(a): Assinatura:

Nome:

Instituição:

Presidente: Assinatura:

Nome:

Instituição: 


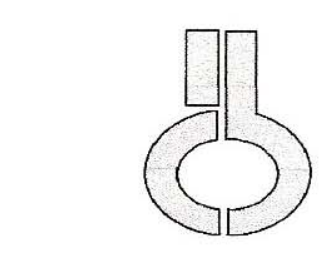

UNIVERSIDADE DE SÃO PAULO INSTITUTO DE CIÊNCIAS BIOMÉDICAS

Cidade Universitária "Armando de Salles Oliveira"

Av. Prof. Lineu Prestes, 2415 - CEP. 05508-000 São Paulo, SP - Brasil

Telefone :(55) (11) 3091-7733 - telefax : (55) (11) 3091-7438

e-mail: cep a icb.usp.br

Comissão de Ética em Pesquisa

CERTIFICADO DE ISENÇÃO

Certificamos que o Protocolo CEP-ICB N ${ }^{\circ}$ 231/07, referente ao projeto intitulado: "Populaçôes de Culex quinquefasciatus (Diptera: Culicidae) do Estado de São Paulo: análises comparativas baseadas em DNA ribossômico, morfometria geométrica alar e micrografia de ovos ${ }^{66}$ sob a responsabilidade de Camila Moratore, foi analisado na presente data pela CEEA - COMISSÃO DE ÉTICA EM EXPERIMENTAÇÃO ANIMAL e pela CEPSH - COMISSÃO DE ÉTICA EM PESQUISA COM SERES HUMANOS, tendo sido deliberado que o referido projeto não envolve manipulação animal ou humana que justifique uma aprovação quanto aos princípios éticos exigidos por ambas as Comissões.

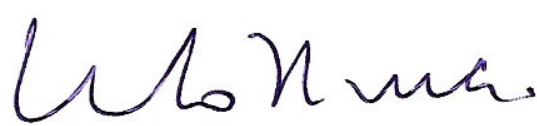

PROF. DR. WOTHAN TAVARES DE LIMA Coordenador da CEEA - ICB/USP
São Paulo, 12 de setembro de 2007.

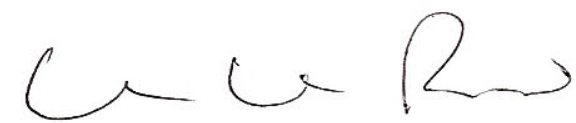

PROF. DR. LuIZ VICENTE RIZZO Coordenador da CEPsh - ICB/USP 
Aos meus queridos pais,

Edna e João, por me apoiarem em todos os momentos da minha vida.

Ao Erich, por sempre estar presente nos bons e maus momentos.

Ao meu eterno e querido avô, (in memorian) que sempre estará no meu coração... 


\section{AGRADECIMENTOS}

Ao Dr. Lincoln Suedek Rocha, por me abrir as portas para um mundo repleto de expectativas e realizações e também pelo incentivo e amizade.

À Mariana Devicari, pela amizade e companheirismo desde a graduação, sempre presente e disposta a ajudar em todos os momentos, dentro e fora do laboratório.

À Maria Cristina Jurcovichi Peruzin, pela amizade construída durante o mestrado e por sempre ajudar e compartilhar seu conhecimento.

Aos novos colegas do grupo de pesquisa Fábio de Almeida e Paloma de Oliveira Vidal.

Ao Dr. Enéas de Carvalho e Dr. José Salvatore Patané, pela contribuição ao longo desse trabalho.

À Dra. Toshie Kawano e a todos os colegas e funcionários do departamento de parasitologia do Instituto Butantan.

À Angela Maria Casemiro de Jesus e Wilma Garcia de Souza do Departamento de Parasitologia do ICB.

Às equipes da Dra. Maria Anice Mureb Sallum, da Dra. Iná Kakitani e do Dr. Delsio Natal, da Faculdade de Saúde Pública, pela valiosa contribuição nas coletas e identificação dos espécimes usados nesse trabalho.

Ao Aristides Fernandes do Departamento de Epidemiologia da Faculdade de Saúde Pública, pela identificação dos espécimes utilizados nesse trabalho.

À FAPESP pelo apoio financeiro.

À minha família, por tudo que representa em minha vida.

Ao Erich, cujo apoio foi imprescindível em todos os momentos durante essa etapa.

A todos os meus amigos e colegas que colaboraram para o desenvolvimento desse trabalho.

A Deus, por mais essa conquista. 
"O que sabemos é uma gota; o que ignoramos é um oceano.”

Isaac Newton

"E um dia os homens descobrirão que esses discos voadores estavam apenas estudando a vidas dos insetos...”

Mário Quintana 


\section{RESUMO}

Moratore C. Padrões genético-morfológicos em populações de Culex quinquefasciatus (Diptera: Culicidae) [Dissertação]. São Paulo: Instituto de Ciências Biomédicas da Universidade de São Paulo; 2009.

Culex quinquefasciatus é uma espécie de mosquito de grande interesse médico, sua distribuição geográfica é pantropical e possui hábitos sinantrópicos, podendo desenvolver-se em ambientes urbanos sob ação de inseticidas e poluentes. Devido ao seu interesse médico, esse culicídeo tem sido alvo de diversas tentativas de controle populacional que acabam enfrentando como fator limitante a microevolução da espécie. Para comparar populações desse culicídeo e verificar a presença de variação populacional indicativa de microevolução, foram coletadas amostras de dois locais dentro do Estado de São Paulo: O Parque Ecológico do Tietê, no município de São Paulo e em Pariquera-Açú, no Vale do Ribeira a 150 km da capital. Os parâmetros biológicos utilizados para tal comparação foram morfometria geométrica alar, micrografia do exocórion de ovos e análise do DNA ribossômico. A análise morfométrica das asas revelou que há diferença de forma e tamanho entre as populações estudadas e também acusou dimorfismo sexual e assimetria bilateral alar nas duas populações. A micrografia de ovos mostrou diferenças interpopulacionais quanto à medida da altura dos tubérculos do exocórion. Os polimorfismos evidenciados por esses dois tipos de análise podem significar diferenciação genética ou plasticidade relacionada aos tipos de ambientes onde as populações estão inseridas. O padrão de bandas observado na análise do DNA ribossômico foi homogêneo, com pequenas exceções, dentro de cada população e também entre as populações, não revelando polimorfismos fixos. O fluxo gênico entre essas populações parece estar sensivelmente reduzido, fato que reflete diretamente a dinâmica dispersional desses mosquitos no Estado de São Paulo, fenômeno que pode ter implicações diretas na transmissão de eventuais doenças veiculadas por esses insetos.

Palavras-chave: Culex quinquefasciatus. Morfometria geométrica alar. Micrografia de ovos. DNAr. Microevolução. Parque Ecológico do Tietê. Pariquera-Açú. 


\begin{abstract}
Moratore C. Genetic-morphometrics patterns in Culex quinquefasciatus populations (Dipteran: Culicidae) [Master Thesis]. São Paulo: Instituto de Ciências Biomédicas da Universidade de São Paulo; 2009.

Culex quinquefasciatus is a pantropical synanthropic species of great medical interest. Several attempts to control this species have fail due to its microvelution of resistance to insecticides. In order to detect populational variation indicative of microevolution, two populational samples from State of São Paulo were compared: São Paulo municipality (Park "Ecológico do Tietê") and Pariquera-Açú municipality. Biological parameters were wing morphometrics, exochorion micrography and ribosomal DNA. Wings characters revealed shape and size divergencies between populations. Exochorion were also interpopulationally different. Polymorphisms observed may be a result of genetic differentiation. rDNA was homogeneous intra and interpopulationally. Gene flow between populations appears to be reduced, which may be closely related to the dispersional dynamics of these mosquitoes. Such interpretation is relevant to a better understanding of transmission of diseases by these insects.
\end{abstract}

Key words: Culex quinquefasciatus. Wing geometric morphometrics. Micrography of eggs. rDNA. Microevolution. Parque Ecológico do Tietê. Pariquera-Açú. 


\section{LISTA DE ABREVIATURAS E SIGLAS}

$\begin{array}{ll}\text { DNAr } & \text { DNA ribossômico } \\ \text { FD } & \text { asas direitas de fêmeas } \\ \text { FE } & \text { asas esquerdas de fêmeas } \\ \text { MD } & \text { asas direitas de machos } \\ \text { ME } & \text { asas esquerdas de machos } \\ \text { MEV } & \text { microscópio eletrônico de varredura } \\ \text { P } & \text { pool de indivíduos } \\ \text { PARIQ } & \text { população de Pariquera-Açu } \\ \text { PET } & \text { população do Parque Ecológico do Tietê } \\ \text { VC } & \text { variável canônica }\end{array}$




\section{LISTA DE FIGURAS}

Figura A.1 - Dois estágios de vida de Culex quinquefasciatus .51

Figura A.2 - Mapa do Estado de São Paulo .52

Figura A.3 - Imagens dos locais de coleta .53

Figura A.4 - Asa e consenso alar de Culex quinquefasciatus .54

Figura A.5 - Dimorfismo sexual na população do PET - Formato alar .55

Figura A.6 - Assimetria bilateral na população de fêmeas do PET - Formato alar .56

Figura A.7 - Assimetria bilateral na população de machos do PET - Formato alar ..... .57

Figura A.8 - Dimorfismo sexual na população de PARIQ - Formato alar .58

Figura A.9 - Assimetria bilateral na população de fêmeas de PARIQ - Formato alar .59

Figura A.10 - Assimetria bilateral na população de machos de PARIQ - Formato alar ....60

Figura A.11 - Comparação Interpopulacional entre fêmeas PET/ PARIQ 61

Figura A.12 - Comparação Interpopulacional entre machos PET/ PARIQ...

Figura A.13 - Distribuição das VCs de fêmeas e machos do PET e PARIQ .63

Figura A.14 - Dendrograma com valores das distâncias de Mahalanobis .64

Figura A.15 - Gráfico de centróides - Diferenças Interpopulacionais e dimorfismo sexual .65 
Figura A.16 - Gráficos de centróides - Assimetria bilateral. .66

Figura A.17 - Southern blotting PET/ PARIQ - DNAr clivado com EcoRI. .67

Figura A.18 - Southern blotting PET/ PARIQ - DNAr clivado com AluI e DraI. .68

Figura A.19 - Southern blotting PET/ PARIQ - DNAr clivado com BamHI e HindIII. ....69

Figura A.20 - Foto do géis com DNAr clivado com as diferentes enzimas de restrição. ...70

Figura A.21 - Imagens de Micrografia de ovos. .71

Figura A.22 - Gráficos das medidas de tamanhos de tubérculos .71 


\section{LISTA DE TABELAS}

Tabela B.1 - Coletas

Tabela B.2 - Altura de tubérculos.

Tabela B.3 - Densidade de tubérculos. .74

Tabela B.4 - Matriz de reclassificação para fêmeas PET/ PARIQ. .75

Tabela B.5- Matriz de reclassificação para machos PET/ PARIQ .75

Tabela B.6 - Distâncias de Mahalanobis .75

Tabela B.7 - Tamanhos de centróides PET .76

Tabela B.8 - Tamanhos de centróides PARIQ .77

Tabela B.9 - Aplicação de testes estatísticos para amostras do PET .78

Tabela B.10 - Aplicação de testes estatísticos para amostras de PARIQ. .78

Tabela B.11 - Aplicação de testes estatísticos para machos e fêmeas de PET e PARIQ....78

Tabela B.12 - Aplicação de testes estatísticos para compração de PET/ PARIQ . .78 


\section{SUMÁRIO}

1 INTRODUÇÃO ....................................................................................................15

1.1 A espécie Culex quinquefasciatus ...............................................................................15

1.2 Diferenciação populacional e microevolução ...............................................................16

1.3 Escolha de parâmetros para caracterização populacional ...........................................18

1.4 Análises do DNA ribossômico.....................................................................................19

1.5 Morfometria geométrica - bases teóricas e aplicação ao estudo morfológico de asas ...................................................................................................................................20

1.6 Micrografia do exocórion de ovos.................................................................................22

1.7 Populações de Culex quinquefasciatus no Estado de São Paulo ..................................23

2 OBJETIVOS ...................................................................................................................24

3 MATERIAL E MÉTODOS ................................................................................................24

3.1 Coleta dos espécimes ............................................................................................................24

3.2 Análises morfométricas..................................................................................................25

3.2.1 Análises de formato alar através das Variáveis Canônicas ......................................25

3.2.2 Tamanhos de centróides.................................................................................................26

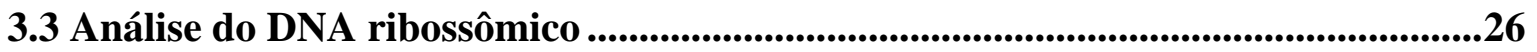

3.3.1 Eletroforese de DNA....................................................................................................27

3.3.2 Obtenção e marcação da sonda heteroespecífca........................................................27

3.3.3 Clivagem com endonuclease, Southern-blot e hibridação .........................................28

3.4 Micrografia do exocórion dos ovos ..................................................................................29

4 RESULTADOS ......................................................................................................................30

4.1 Coleta dos espécimes ................................................................................................................30

4.2 Análises morfométricas.........................................................................................................30

4.2.1 Diagrama de grades...........................................................................................................30

4.2.2 Análises de forma alar através das Variáveis Canônicas ..........................................31

4.2.3 Tamanhos de centróides..................................................................................................32

4.3 Análise do DNA ribossômico .....................................................................................32

4.4 Micrografia de ovos...................................................................................................................33

5 DISCUSSÃO ..............................................................................................................33

6 CONCLUSÕES...................................................................................................................37

REFERÊNCIAS BIBLIOGRÁFICAS ....................................................................41

ANEXO A - Figuras...........................................................................................50

ANEXO B - Tabelas..............................................................................................................72

ANEXO C - Trabalho Publicado....................................................................................................79 


\section{INTRODUÇÃO}

\subsection{A espécie Culex quinquefasciatus}

Culex quinquefasciatus é uma das espécies integrantes do complexo Culex pipiens e apresenta distribuição geográfica pantropical (Consoli e Oliveira, 1994; Forattini, 2002). As formas adultas dessa espécie têm hábitos sinantrópicos, podem reproduzir-se em criadouros artificiais e as fêmeas são hematófagas antropofílicas e eventualmente zoofílicas. Suas larvas podem se desenvolver em coleções hídricas poluídas de ambientes rurais ou urbanos (Forattini, 2002). O hábito hematofágico das fêmeas dessa espécie tem diretas implicações epidemiológicas.

Em geral as fêmeas das espécies vetoras de parasitas são anautógenas, ou seja, dependem de complementos alimentares de aminoácidos e outras substâncias para desenvolvimento de seus ovaríolos e ovócitos para reprodução. Para tal, praticam hematofagia, sugando através de picadas o sangue de animais, entre eles o homem. Ao picar animais infectados por parasitas, o mosquito ingere sangue contaminado e passa a hospedar esses parasitas, os quais, freqüentemente, possuem a capacidade de sobreviver no interior do mosquito. No caso de mosquitos transmissores de arbovírus, é ainda possível que esses vetores adquiram os parasitas a partir de sua progenitora, através de transmissão transovariana (Rosen, et al., 1983). Uma vez que os mosquitos contaminados venham a picar um outro animal, os parasitas poderão ser transferidos pelas peças do aparelho bucal para esse novo doador do sangue (Rey, 2001).

A importância médica de $C x$. quinquefasciatus deve-se ao fato de esta possuir competência vetora para diversos agentes etiológicos de doenças humanas e(ou) animais. Essa espécie é a principal vetora de filariose bancroftiana humana na região Neotropical e pode transmitir o vírus do Nilo Ocidental (WNV) causador de encefalite humana (Reisen, et al., 2008). Há um temor de que essa espécie possa vir a transmitir o vírus WNV entre aves e humanos no Brasil, já que este país tem recebido aves migrantes de regiões com presença de WNV e que são potencialmente hospedeiras desse vírus (Luna, et al., 2003). Recentemente, a disseminação do vírus para o hemisfério sul foi confirmada em território sul-americano, onde foi detectada soropositividade para WNV em eqüídeos na Colômbia e Venezuela e o isolamento do vírus nestes animais na Argentina (Pauvolid-Corrêa e Varella, 2008). 
Estratégias para controle dessa espécie e de outros culicídeos, têm sido desenvolvidas e aplicadas há décadas. Há métodos químicos, que atualmente utilizam piretróides e derivados de Bacillus thuringienses (Forattini, 2002; Gill, et al., 1992); há o método ambiental, que visa a eliminação de criadouros dos mosquitos (Forattini, 2002); e o biológico, que faz uso de parasitóides e predadores, como por exemplo o uso de ninfas de odonata para predação de larvas de Cx. quinquefasciatus (Mandal, et al., 2008). Métodos alternativos visando utilizar mosquitos transgênicos estão em promissor desenvolvimento (Benedict e Robinson, 2003; Marrelli, et al., 2006; Sperança e Capurro, 2007).

A eficácia dos métodos para controlar uma espécie pode ser limitada pela sua microevolução. Compreende-se por "microevolução" o conjunto de alterações evolutivas ocorridas em níveis taxonômicos infra-específicos, ou seja, envolvendo populações (Futuyma, 1997; Ridley, 2003).

A resistência a inseticidas, a tolerância a poluentes urbanos, a tendência à domiciliação e antropofilia, podem decorrer de adaptações conferidas pela fixação de caracteres relacionados aos processos microevolutivos sofridos pelas populações de mosquitos em poucas gerações (Hemmingway e Karunaratne, 1998; Lenormand e Raymond, 2000; Donely, et al., 2002). Consequentemente, para que haja eficácia nos métodos de controle é primordial conhecer e identificar os padrões e processos da microevolução em culicidae.

\subsection{Diferenciação populacional e microevolução}

Processos microevolutivos ocorrem dinamicamente em populações como resultado da conjunção de fatores bióticos e abióticos. Por vezes, resumem-se a variações alélicas quantitativas ou qualitativas, amplificações/deleções gênicas ou rearranjos cromossômicos. Os padrões genotípicos, fenotípicos e cariotípicos produzidos por esses processos dependem da atuação de eventos selecionistas ou estocásticos, são influenciados pela atuação do fluxo gênico e podem culminar em diferenciação ou convergência desses padrões nos indivíduos envolvidos (Futuyma, 1997; Ridley, 2003).

A dinâmica evolutiva das populações de Culicidae é peculiar devido a diversas características biológicas deste grupo e pode pronunciar-se em curtos intervalos temporais e espaciais. Cx. quinquefasciatus, assim como outros culicídeos, apresenta flutuações populacionais amplas e freqüentes, e seu ciclo de vida é influenciado por condições ambientais instáveis como temperatura, regime pluviométrico, disponibilidade de coleções hídricas e pela presença humana (Hayes, 1975; Mouchet e Carnevale, 1997; Kovats, 2000; 
Forattini, 2002; Ahumada, et al., 2004). Soma-se a isso o fato de reproduzirem-se em gerações rápidas, podendo completar um ciclo de vida em poucos dias. Essas propriedades em conjunto resultam freqüentemente em rápida evolução de suas populações.

Diversos são os exemplos de microevolução Culicidae. É marcante a característica do complexo $C x$. (Cx.) pipiens em desenvolver resistência a inseticidas (Yebakima, et al., 2004; Labbé, et al., 2007). A espécie Cx. quinquefasciatus, já foi reportada por ampliar significativamente sua resistência a inseticidas em poucos anos (Wirth e Georghiou, 1999; Yebakima, et al., 2004). No Estado da Flórida, Estados Unidos, foram detectadas variações alélicas de isozimas em populações dessa mesma espécie ao longo de oito meses (Nayar, et al., 2003).

A diferenciação de populações geograficamente isoladas é uma questão importante na evolução de populações de mosquitos, pois variações geográficas são comuns nas populações que possuem distribuição geográfica ampla e descontínua a ponto de interromper o fluxo gênico. Há casos em que pequenas distâncias geográficas já são suficientes para observação desses fenômenos. Em Londres, Inglaterra duas populações de Cx. pipiens uma habitante dos túneis subterrâneos do metrô e a outra habitante da superfície possuem divergências genéticas significativas (Byrne e Nichols, 1999).

A caracterização de populações, descrevendo-as quanto a padrões genéticos, morfológicos, comportamentais e comparando-as ao longo de transectos geográficos ou temporais é adotada como passo inicial para o estudo da microevolução. Esse conjunto de dados permite o reconhecimento de padrões microevolutivos e, o acúmulo desses dados ao longo do tempo, pode possibilitar a observação de processos microevolutivos. Estudos geralmente incluem estimativa de fluxo gênico entre populações, já que a velocidade de espalhamento das variações genéticas é altamente infuenciada pela reprodução efetiva entre as populações (Roderick, 1996).

Nesse contexto de caracterização populacional para entendimento da microevolução, a espécie $C x$. quinquefasciatus tem sido estudada quanto à sua estrutura genética populacional e diferenciação populacional em diversas partes do mundo, devido às suas propriedades biológicas (Fonseca, et al., 2000; Nayar, et al., 2003). Duas populações de CX. quinquefasciatus da Índia foram comparadas através do DNA mitocondrial, analisando a seqüência do gene 16S ribossomal, o qual indicou diferenças entre elas (Chaudhry e Kohli, 2007). Surpreendentemente, na América do Sul, os estudos populacionais envolvendo esse culicídeo são escassos. No Brasil, populações estão sendo caracterizadas quanto a 
variabilidade do ITS2 (Marrelli, 2006) (comunicação pessoal) ${ }^{1}$. Populações desse culicídeo podem ser encontradas em grande parte dos municípios do Estado de São Paulo, assim como em outras regiões, vivendo sob condições ambientais diversas. Essas características são típicas de espécies que apresentam variação interpopulacional, evidenciando a necessidade de estudos direcionados a esse táxon.

\subsection{Escolha de parâmetros para caracterização populacional}

Abordando simultaneamente múltiplos parâmetros comparativos, pode-se obter maior robustez nos testes de hipóteses em uma caracterização populacional. Esse tipo de abordagem permite encontrar um marcador com melhor nível de resolução para a detecção de variações fenópticas e genópticas, pois os caracteres em uma espécie evoluem em taxas e velocidades diversas (Sene, et al., 1988; Reinert, et al., 1997; Rocha, 2005)

Com a utilização de vários tipos de abordagem, é gerada também uma base de dados maior, ampliando a possibilidade de correlacionar dados fenéticos, fisiológicos, ecológicos etc. Em Diptera, um exemplo de múltiplas abordagens empregadas com sucesso foi realizado com Anastrepha sororcula (Tephritidae), uma praga da fruticultura brasileira (ROCHA, 2005). Em relação à entomologia médica, foram caracterizadas populações de Anopheles darlingi na América do Sul através de isozimas, RAPD, ITS2 e morfologia de ovos (Manguin, et al., 1999). Além disso, estudos do complexo An. quadrimaculatus envolveram caracteres morfológicos, cromossômicos, genéticos, bioquímicos e ecológicos (Reinert, et al., 1997).

Há uma ampla série de parâmetros utilizados como marcadores em estudos populacionais. Para citar alguns, há os dados moleculares (DNAmt, DNAr, introns de genes nucleares, microssatélites, isozimas), dados cromossômicos (número, rearranjos, localização de genes in situ) e dados morfológicos não-notáveis (morfometria tradicional ou geométrica

de asas, ovos, etc). É recomendável que alguns parâmetros sejam empregados em conjunto, de forma a diversificar a base de dados favorecer a correlação entre os parâmetros. Dentre eles, alguns são particularmente úteis em Diptera e serão detalhados a seguir: (a) caracteres do DNA ribossômico; b) morfometria geométrica de asas; c) micrografia do exocórion de ovos.

\footnotetext{
${ }^{1}$ Dr. Mauro Toledo Marrelli, departamento de Epidemiologia da Faculdade de Saúde Pública da USP, 2006.
} 


\subsection{Análises do DNA ribossômico}

Uma tradicional ferramenta de diagnósticos de populações divergentes é a análise do DNA ribossômico (Hillis e Dixon, 1991; Roderick, 1996). O DNA ribossômico (DNAr) é composto por genes ribosssomais, espaçadores internos (ITS), espaçadores externos (ETS) e espaçadores intergênicos (IGS). Essas regiões dispõem-se intercaladas e apresentam-se em centenas de cópias no genoma. Elas evoluem em diferentes velocidades e, devido a essa diversidade de taxas evolutivas, podem revelar relações filogenéticas em diversos níveis taxonômicos (espécies, famílias, filos) dependendo da região estudada (Hillis e Dixon, 1991).

Os genes ribossomais são a porção conservada do DNAr, ou seja, evoluem lentamente em muitos taxa. Por outro lado, os espaçadores internos (ITS), os externos (ETS) e os intergênicos (IGS) são a porção não-conservada do DNAr, e evoluem rapidamente, podendo apresentar-se divergentes entre espécies ou populações. Embora haja alta velocidade de variação dos espaçadores ITS, ETS e IGS, as suas múltiplas cópias in tandem tendem a evoluir de forma semelhante dentro de um deme populacional, devido à ação da "evolução em concerto" (Dover, 1982).

Esses espaçadores gênicos são considerados bons marcadores moleculares por serem muitas vezes "espécie-específicos" ou "população-específicos". Isso é em parte devido à rápida divergência de suas sequências entre as populações e o efeito da evolução em concerto em homogeneizar as múltiplas cópias dos espaçadores de DNAr intrapopulacionalmente. A intensidade do fluxo gênico é diretamente proporcional à similaridade dos espaçadores entre as populações. Comparar tais marcadores pode acusar ausência de fluxo gênico, um evento importante na identificação de processos de divergência populacional ou até de especiação.

A análise de restrição por endonucleases pode auxiliar na caracterização desses espaçadores. Quando polimorfismos do DNA ribossômico abrangem sítios reconhecidos por endonucleases de restrição, os fragmentos de restrição são polimórficos, e podem ser evidenciados por hibridação e "Southern blot" com sondas de DNAr 45S, como ocorrido para populações da mosca-das-frutas Anastrepha sororcula (Rocha, 2005) e do complexo An. gambiae s.1. (McLain e Collins, 1989).

Uma abordagem que tem sido muito utilizada em estudos envolvendo culicídeos é a análise de espaçadores de DNAr por sequenciamento de DNA. Para o sequenciamento em culicinae, principalmente em anofelinos, o espaçador ITS2 tem sido o mais utilizado (RosaFreitas, et al., 1998; Marrelli, et al., 2005; Gentile, et al., 2001; Collins e Paskewitz, 1996; Marrelli, et al., 1999). 
Em estudo populacionais de Anopheles, os caracteres do DNAr têm sido de grande utilidade, e é necessário que esse tipo de análise seja estendida a outros gêneros com representantes de interesse médico no Brasil, como Culex, Aedes, etc. Nos centros urbanos do Estado de São Paulo estão presentes espécies que vivem sob constante pressão seletiva a qual pode interferir no curso de sua evolução, como por exemplo $C x$. quinquefasciatus. Na África e América do norte essa espécie já foi submetida a esse tipo de análise (Severini, et al., 1996), no Estado de São Paulo estudos recentes empregando sequenciamento do ITS2 têm sido desenvolvidos para esse culicídeo (Marrelli, 2006) (Comunicação pessoal) ${ }^{2}$.

\subsection{Morfometria geométrica - bases teóricas e aplicação ao estudo morfológico de asas}

Quando populações apresentam variações morfológicas não-notáveis à observação direta, como variações na razão entre múltiplas dimensões de uma determinada estrutura corporal, para detecção e quantificação de tais variações torna-se necessário recorrer a abordagens alternativas, como as análises morfométricas. A morfometria é a formalização matemática das dissimilaridades entre formas geométricas de objetos.

A recém-criada "morfometria geométrica" é uma ferramenta de alto poder de resolução que permite a comparação de padrões corporais a partir de caracteres multivariados, ou seja, considerando-se simultaneamente várias características de uma estrutura corporal complexa (Rohlf, 1993; Monteiro e Reis, 1999). Na coleta de dados para a morfometria geométrica são usados "pontos anatômicos", que são pontos de referência da estrutura corporal em estudo. São tomadas então as suas coordenadas posicionais sobre um plano cartesiano imaginário que circunscreve a estrutura corporal, as quais são posteriormente ordenadas em tabelas de dados. A partir desses dados, pode-se efetuar estudos estatísticos da variação morfométrica, comparar a magnitude das variações, etc (Bookstein, 1997; Rohlf, 1993; Monteiro e Reis, 1999).

Um dos testes estatísticos, a análise das variáveis canônicas (VCs) fornece uma descrição das diferenças de forma entre grupos especificados a priori (populações p. ex.), utilizando um conjunto de dados multivariados. Nessa análise, há redução da dimensionalidade dos dados, que passam a ser expressos como variáveis latentes representadas em gráficos bidimensionais. As variáveis canônicas sumarizam de modo decrescente a magnitude das diferenças de forma entre os grupos em relação às existentes

\footnotetext{
${ }^{2}$ Dr. Mauro Toledo Marrelli, departamento de Epidemiologia da Faculdade de Saúde Pública de São Paulo, 2006.
} 
dentro dos grupos, ou seja, a VC1 apresenta maior resolução de discriminação amostral que a VC2, e assim por diante (Monteiro e Reis, 1999).

Outro teste possível é o do tamanho do centróide que permite detecção de dissimilaridade não-alométrica de tamanho de estruturas. O centróide é o ponto imaginário que representa o centro geométrico da asa e é determinado pela média dos valores posicionais no plano cartesiano de todos os pontos anatômicos de uma mesma asa. O tamanho do centróide é um vetor que sintetiza todos os valores posicionais considerados no cômputo do centróide. Formalmente, tamanho do centróide é a raiz quadrada da soma dos quadrados das distâncias de cada ponto anatômico ao centróide. Na ausência de alometria, essa é a única medida de tamanho que não se correlaciona com as variáveis de forma. $\mathrm{O}$ tamanho do centróide, portanto varia com o tamanho da asa e é uma forma de sumarizar o tamanho dessa estrutura em uma única variável.

Em suma, as principais propriedades da morfometria geométrica são a possibilidade de análises multivariadas, com múltiplas variáveis simultaneamente e a possibilidade de recuperar informações de forma e tamanho independentemente. Conseqüentemente seu poder de resolução é alto e permite gerar diversos marcadores taxonômicos ou populacionais.

Comumente em insetos as asas têm sido as principais estruturas-alvo de estudos morfométricos, pois prestam-se adequadamente a isso devido à sua forma predominantemente bidimensional e o seu grande número de caracteres: os pontos determinados pelo encontro de nervuras alares. A morfometria geométrica permitiu, ao lado de outros marcadores, caracterizar populações da mosca-das-frutas Anastrepha sororcula a partir de caracteres das asas desses insetos (Rocha, 2005), as quais são indistinguíveis quando observadas diretamente. Entre os insetos de interesse médico, há o exemplo do hemíptero Triatoma infestans, que possui uma estruturação populacional complexa, de acordo com caracteres morfométricos alares (Schachter-Broide, et al., 2004).

A morfometria geométrica aplicada a Culicidae tem sido pioneiramente empregada por um grupo de pesquisadores da Tailândia. Esses pesquisadores publicaram dois estudos utilizando essa ferramenta, em que foi demonstrada variação temporal de forma (Jirakanjanakit, et al., 2008) e variação de tamanho (Jirakanjanakit, et al., 2007) em asas de Ae. aegypti.

Espécies de ampla distribuição geográfica e capazes de explorar distintos ambientes como $C x$. quinquefasciatus são bons candidatos a estudos populacionais envolvendo morfometria geométrica alar. Esse tipo de ferramenta tem se mostrado útil tanto para Culex sp. e Aedes sp., de acordo com os resultados do nosso grupo de pesquisa, quanto para Ae. 
aegypti, conforme mostram os estudos de Jirakanjanakit, et al. (2007, 2008). Portanto, talvez essa ferramenta possa se tornar uma tendência em culicidologia (Dujardin, 2008).

Para Culicidae, o uso das asas em estudos morfométricos é particularmente interessante, pois características das asas freqüentemente correlacionam-se com outras características biológicas dos mosquitos ligadas à sua importância médica, como capacidade de vôo, produção de sons alares de côrte pré-cópula, e até fecundidade (Brogdon, 1994, 1998). As análises de morfometria geométrica alar aplicadas em Culicidae permitem a comparação entre populações geográficas e espécies crípticas, possibilitando avaliar dimorfismo sexual alar, variações temporais em cativeiro e na natureza, assimetria alar, efeitos morfológicos da presença/ausência de inseticidas, entre outros (Jirakanjanakit, et al., 2007, 2008; Moratore e Suesdek, 2008).

\subsection{Micrografia do exocórion de ovos}

O exocórion dos ovos de Culicidae exibe características morfológicas peculiares, que muitas vezes conferem especializações como proteção à dessecação, permeabilidade a trocas gasosas, flutuação e adesão aos demais ovos quando organizados em "jangadas" (como em Culex) (Sahlen, 1996; Service, 2004; Soumaré e Ndiaye, 2005). A descrição morfológica do córion por micrografia de varredura tem permitido a caracterização dos ovos de diversos culicídeos de interesse médico e tem agregado diversos caracteres de potencial uso taxonômico ou filogenético (Sahlen, 1996; Forattini, 2002; Reinert, 2005).

Em geral, os caracteres analisados nos ovos são merísticos, como contagem de tubérculos; morfométricos, como razões matemáticas entre dimensões e também descritivos da ornamentação do exocórion. Essa abordagem tem especial importância para estudos populacionais e de caracterização de complexos de espécies, já que há características morfológicas dos ovos que são espécie-específicas, enquanto outras podem apresentar variação populacional (Sahlen, 1996; Junkum, et al., 2004).

Devido a essas razões, é muito recomendável utilizar caracteres dos ovos, descritos por microscopia de varredura, para testar hipóteses de existência de diferenciação populacional ou de espécies crípticas em Culicidae. A espécie Cx. quinquefasciatus é aparentemente uma ótima candidata a estudos populacionais envolvendo micrografia de ovos, já que ainda não foi submetida a estudos dessa natureza e devido às suas já mencionadas características, como interesse médico, ampla distribuição geográfica, ecletismo na exploração de habitats, etc. 


\subsection{Populações de Culex quinquefasciatus no Estado de São Paulo}

Algumas localidades de ocorrência de Cx. quinquefasciatus no Estado de São Paulo merecem grande atenção. No município de São Paulo, a espécie é muito abundante e responsável por grande incômodo ao homem. Nessa cidade há populações desses mosquitos em um importante pólo turístico, o Parque Ecológico do Tietê (PET). Nessa região, existe um canal de circunvalação conhecido como "Rio Negrinho", que fica na divisa do PET com o bairro Jardim São Francisco e recebe esgoto doméstico da área urbana adjacente, onde ocorre intensa proliferação de imaturos de CX. quinquefasciatus (Urbinatti, et al., 2001; Taipe-Lagos e Natal, 2003; Laporta, et al., 2006).

Um agravante de significado epidemiológico reside no fato de o PET abrigar diversas espécies de vertebrados autóctones ou migradores, potenciais hospedeiros de agentes etiológicos de zoonoses transmissíveis por mosquitos. Além dos animais e moradores da região, milhares de pessoas que visitam mensalmente o parque estão sujeitas à atividade hematofágica dessa espécie. Em um estudo recente, Laporta e Sallum (2008) avaliaram a densidade, sobrevivência e hábito alimentar de $C x$. quinquefasciatus e concluíram que essa espécie é epidemiologicamente relevante na área do PET como potencial espécie vetora ou peste urbana e deve ser objetivo do programa de controle de vetores no município de São Paulo.

No município de Pariquera-Açu (PARIQ), uma região cuja culicidofauna é relativamente bem conhecida, a espécie é também muito abundante, incômoda ao homem e eventualmente incômoda ao gado e animais domésticos (Forattini, et al., 1987a, 1987b, 1990). Trata-se de uma região particularmente interessante e distinta do município de São Paulo, pois abrange áreas urbanas e semi-rurais e rurais próximas ao ecossistema de mata Atlântica da Serra do Mar. Assim como o local é geograficamente distante de São Paulo, é presumível que este abrigue populações de culicídeos com caracteres biológicos também peculiares.

Os municípios de São Paulo e Pariquera-Açu são, portanto, regiões de grande relevância culicidológica. Não se sabe se há diferenciação genético-morfológica ou se há fluxo gênico entre as populações dessas duas localidades. Sugere-se aqui então um estudo de caracterização populacional de $C x$. quinquefasciatus abrangendo essas duas localidades do Estado de São Paulo e realizando o seguinte teste de hipótese: Existe diferenciação genéticomorfológica entre as populações destes locais geograficamente distantes: São Paulo (PET) e Pariquera-Açu (PARIQ)? 
Apresentamos a seguir nossa contribuição para a culicidologia médica, com estudos relacionados ao $C x$. quinquefasciatus. Nesses estudos, são utilizadas técnicas que também poderão ser empregadas em estudos envolvendo outros culicídeos. 


\section{OBJETIVOS}

Comparar populações de $C x$. quinquefasciatus visando testar a seguinte hipótese:

Existe diferenciação genético-morfológia entre as populações destes locais geograficamente distantes e ecologicamente distintos: São Paulo (PET) e Pariquera-Açú (PARIQ)?

Parâmetros biológicos utilizados nas comparações:

1. DNA ribossômico: variabilidade de sítios de restrição do DNA ribossômico evidenciados por Southern blot e hibridação;

2. Morfometria geométrica de asas;

3. Micrografia do exocórion de ovos. 


\section{MATERIAL E MÉTODOS}

\subsection{Coleta dos espécimes}

Exemplares de Cx. quinquefasciatus (Figura 1) foram coletados em dois locais no Estado de São Paulo (Figura 2): na região do Parque Ecológico do Tietê (Figura 3- A e B), no município de São Paulo, e no município de Pariquera-Açú (Figura 3- C e D). Para o esforço de coleta, contamos com o auxílio da Prof ${ }^{\mathrm{a}}$. Dr ${ }^{\mathrm{a}}$. Maria Anice Mureb Sallum da Faculdade de Saúde Pública da USP. Os dados das coletas estão listados na Tabela 1. A amostra A1T1 já havia sido coletada antes do início desse projeto. Nos dois locais, larvas foram coletadas diretamente nas coleções hídricas, trazidas vivas em recipientes com água e mantidas a $20{ }^{\circ} \mathrm{C}$ com fotoperíodo natural, até transformarem-se em adultos.

Mosquitos adultos (machos e fêmeas) foram capturados com aspiradores entomológicos. Esses mosquitos adultos e os provenientes de larvas foram armazenados em nitrogênio líquido $\left(-190^{\circ} \mathrm{C}\right)$ ou em etanol $70 \%$ e usados respectivamente para análises de DNA ribossômico e morfometria geométrica alar.

As fêmeas adultas que estavam com ovário desenvolvido foram acondicionadas vivas individualmente em recipientes de vidro contendo papel filtro e um pouco de água, para que elas pudessem ovipor as jangadas de ovos (Bates e Roca-Garcia, 1945). Esses ovos foram conservados em glutaraldeído $2,5 \%$ a $4{ }^{\circ} \mathrm{C}$ e posteriormente usados para fazer a micrografia do exocórion.

\subsection{Análises morfométricas}

Os métodos de morfometria geométrica seguiram em linhas gerais os empregados por Rocha (2005). Asas direitas e esquerdas de machos e fêmeas, após remoção das escamas, foram montadas com uma resina sintética chamada Entellan entre lâmina-lamínula para análise morfométrica. Imagens dessas asas foram capturadas através de câmera fotográfica digital Leica 320 acoplada a um microscópio estereoscópio Leica S6, no aumento de 40X. Foram analisados cerca de 70 indivíduos (35 machos e 35 fêmeas) de cada população amostrada (A1T1, A33T1, A36T1 e A40T3), conforme mostrado na Tabela 1.

Sobre essas imagens, e com o auxílio do "software" TpsDig V.1.40 (QSC - James Rohlf), foram tomadas as coordenadas posicionais de cada um dos 18 pontos anatômicos sobre um plano cartesiano (Figura 4). Sobre esses dados foram computados os tamanhos de 
centróides e as variáveis canônicas (VCs), com o auxílio dos programas de computador TpsUtil 1.29, TpsRelw 1.39 e TpsRegr (QSC - James Rohlf) e Statistica 7.0 (StatSoft).

\subsubsection{Análises de forma alar através das Variáveis Canônicas}

As variáveis canônicas foram obtidas a partir das tabelas de dados posicionais dos pontos anatômicos com o auxílio do programa de computador Statistica 7.0. as variáveis canônicas foram empregadas nas comparações intra e interpopulacionais e representadas em gráficos bidimensionais. Dentre as variáveis canônicas geradas para essas comparações, apenas a primeira e a segunda (VC1 e VC2) foram consideradas para interpretação, já que são por definição as mais informativas (Monteiro e Reis, 1999). Para essas comparações também foi utilizado o cálculo das Distâncias de Mahalanobis, que é uma distância linear, semelhante à distância Euclidiana, porém medida entre pontos num espaço multidimensional.

Comparações par-a-par efetuadas entre as amostras populacionais, além de comparações par-a-par entre machos e fêmeas (para verificar possível dimorfismo sexual) e entre indivíduos do mesmo sexo dentro da mesma população (para verificar possível assimetria bilateral), foram também realizadas, gerando uma variável canônica para cada caso, a qual foi utilizada no estudo de deformações em diagramas de grades. Os diagramas de deformações foram obtidos a partir da regressão dos valores da variável canônica sobre os componentes de forma, em cada comparação. Esses diagramas foram gerados através do programa TpsRegr (QSC - James Rohlf). As deformações representam quais as principais dissimilaridades quanto à posição dos pontos anatômicos entre as duas configurações alares submetidas à comparação.

\subsubsection{Tamanhos de centróides}

Os tamanhos de centróides foram utilizados nas comparações de amostras par-a-par tendo sido efetuadas intra e interpopulacionalmente. Análises estatísticas bicaudais ao nível de rejeição 0,05 foram utilizadas nas comparações baseadas nos tamanhos de centróides. $\mathrm{O}$ teste estatístico de normalidade Kolmogorov-Smirnov foi utilizado para verificar se as amostras analisadas apresentavam distribuição Gaussiana (distribuição normal), onde p >0,1. Os outros testes estatísticos empregados foram: o Teste $\mathrm{T}$ paramétrico para amostras de distribuição normal e variância homogênea, Teste T com correção de Welch para amostras de 
distribuição normal, porém variâncias não-homogêneas e teste não-paramétrico de MannWhitney para amostras de distribuição não-normal.

\subsection{Análise do DNA ribossômico}

Adultos e larvas das amostras populacionais A14T1, A20T3 e A22T2 foram utilizados para extração de DNA genômico e análises de DNA ribossômico. A extração de DNA foi feita isoladamente para cada indivíduo e também em pools, segundo o método de Jowett (1986), com modificações, como descrito a seguir.

Os indivíduos conservados em nitrogênio líquido foram macerados em solução de homogeneização [Tris-HCl $10 \mathrm{mM}(\mathrm{pH}=7,5), \mathrm{NaCl} 60 \mathrm{mM}$, EDTA $50 \mathrm{mM}$ ]. Aos homogeneizados foi adicionada a solução de lise [SDS 1,25\%, Tris- $\mathrm{HCl}$ 0,3 M (pH=9,0), EDTA $0,1 \mathrm{M}$, sacarose $5 \%$, proteinase $\mathrm{K}$ a $100 \mu \mathrm{g} / \mathrm{ml}$. A mistura foi incubada a $65{ }^{\circ} \mathrm{C}$ por 1 hora para "lise" das células e clivagem das proteínas em peptídeos menores pela proteinase $\mathrm{K}$.

Prosseguiu-se com uma incubação a $4{ }^{\circ} \mathrm{C}$ por 45 min e logo após uma centrifugação a $12.000 \mathrm{~g} \mathrm{a} 4{ }^{\circ} \mathrm{C}$. Após a centrifugação formaram-se duas fases na mistura. O precipitado, que contém peptídeos, foi descartado e o sobrenadante contendo ácidos nucléicos e sais foi transferido para outro microtubo e misturado com o dobro de seu volume ( 2 volumes) de etanol $100 \%$ para a precipitação do DNA. Após cinco minutos de incubação à temperatura ambiente, as amostras foram novamente centrifugadas a $12.000 \mathrm{~g}$ à temperatura ambiente, por 5 minutos. O sobrenadante foi descartado e ao precipitado foi adicionado $1 \mathrm{ml}$ de etanol $70 \%$, e assim as amostras foram submetidas a uma última centrifugação à temperatura ambiente e $12.000 \mathrm{~g}$ por 5 minutos.

O precipitado foi seco e ressuspendido em $20 \mu \mathrm{l}$ de $\mathrm{H} 2 \mathrm{O}$ milli-Q (Millipore) para cada amostra, que foram então armazenadas a $-20{ }^{\circ} \mathrm{C}$. Para eliminar o RNA, as amostras de DNA recém-extraído foram tratadas com RNAase (Ribonuclease A, Sigma) a uma concentração final $100 \mu \mathrm{g} / \mathrm{ml}$ por 1 hora a $37^{\circ} \mathrm{C}$.

\subsubsection{Eletroforese de DNA}

Eletroforeses de DNA foram realizadas para conferir a eficiência das extrações de DNA e após a digestão com endonuclease de restrição. Foram utilizadas cubas horizontais com solução TAE $1 \mathrm{X}$ como tampão de corrida, que foi de aproximadamente 30 minutos sob tensão 
elétrica de $60 \mathrm{~V}$ e corrente de $60 \mathrm{~mA}$ constantes, conforme recomendado por (Sambrook, et al., 1989). A cada amostra de DNA aplicada em gel, foi adicionada como tampão de amostra uma solução contendo 0,015\% azul de bromofenol, 0,015\% de xilenocianol e 30\% de glicerol a uma concentração final de 20\%. Os géis foram corados com SyBr safe (Life Technologies) a concentração $1 \mathrm{X}$ e foram fotografados em fotodocumentador digital UVP sob irradiação Ultravioleta de $300 \mathrm{~nm}$.

\subsubsection{Obtenção e marcação da sonda heteroespecífica}

O fragmento de DNAr "Dm238" foi usado como sonda na etapa de hibridação após "Southern blot" em membrana, assim como utilizado em Rocha (2005). Este fragmento representa uma unidade repetitiva completa do DNAr 45S de D. melanogaster, a qual apresenta a seguinte seqüência de genes e espaçadores no sentido $5^{\prime}-3^{\prime}$ : 18S - ITS1 - 5.8S ITS2 - 2S - ITS3 - 28S - NTS.

A unidade "Dm238" tem sua seqüência de bases descrita no banco mundial de dados genéticos GenBank (www.ncbi.nih.gov), sob o código de acesso M21017 e está clonada sob a forma do plasmídeo pDm238 inserido em células de Escherichia coli DH5a, conforme descrito por Tautz, et al., (1988). Estoques de E. coli DH5a contendo o plasmídeo pDm238 utilizadas neste trabalho estão armazenados em $50 \%$ de glicerol à temperatura de $-80{ }^{\circ} \mathrm{C}$.

Culturas de E. coli DH5 $\alpha$ contendo pDm238 foram estabelecidas a partir de amostras de $10 \mu \mathrm{l}$ da suspensão-estoque e inoculadas em frascos contendo $3 \mathrm{ml}$ de meio de cultura LB sob seleção de antibiótico ampicilina $(10 \mu \mathrm{g} / \mathrm{ml})$, que foram incubados a $37{ }^{\circ} \mathrm{C}$ por 15 horas sob agitação constante, segundo procedimento-padrão de clonagem (Sambrook, et al., 1989).

Após a incubação, os plasmídeos pDm238 foram extraídos das células DH5 $\alpha$ com o "kit de miniprep" Concert Plasmid Preparation (Invitrogen, USA). O plasmídeo pDm238 foi submetido à clivagem com a endonuclease EcoRI, o que permitiu a liberação do inserto Dm238, de tamanho aproximado de $12 \mathrm{~kb}$. A mistura de reação de restrição contendo inserto e plasmídeo separados foi submetida à eletroforese em gel de agarose para recuperação do inserto, que foi eluído de gel através do "kit" Concert Gel Extraction (Invitrogen, USA).

A sonda para hibridações foi marcada com biotina através da utilização de "primers" randômicos ("kit Bioprime DNA labelling system" - Life Technologies). Para obtenção de cada amostra de $2 \mu \mathrm{g}$ de sonda biotinilada, cerca de $50 \mathrm{ng}$ de inserto Dm238 foram utilizados e ao final a sonda foi armazenada em solução aquosa à temperatura de $-20{ }^{\circ} \mathrm{C}$. 


\subsubsection{Clivagem com endonuclease, Southern blot e hibridação}

Nos experimentos de "Southern blot" amostras de DNA de Cx. quinquefasciatus das duas populações (PET e PARIQ) foram utilizados como DNA-alvo. O DNA genômico destas espécies foi clivado com EcoRI, AluI, DraI(AhaIII), BamHI e HindIII utilizando-se 2 U de endonuclease por $1 \mu \mathrm{g}$ de DNA e foi submetido a eletroforese. Após a eletroforese, o DNA do gel foi desnaturado através da imersão do gel em solução $\mathrm{NaCl}$ 1,5 M, NaOH 0,5 N, logo após foi neutralizado em solução Tris $\mathrm{HCl} 1 \mathrm{M}(\mathrm{pH} 7,4), \mathrm{NaCl} 1,5 \mathrm{M}$ e por fim foi transferido para uma membrana de "nylon" (Pall) conforme a metodologia "Southern blot" de transferência capilar em condições neutras (Sambrook, et al., 1989). A fixação do DNA à membrana foi feita por aquecimento no forno microondas durante 1 a 2 minutos.

Os procedimentos de pré-hibridação, hibridação e detecção foram feitos, com algumas modificações, conforme recomendado pelo fabricante do sistema de detecção de sinal de hibridação em membranas por reação de fosfatase alcalina seguida de detecção por colorimetria kit K0661 (Fermentas).

Os passos que incluíam hibridações, incubações e lavagens da membrana foram realizados em garrafas de hibridação "Schott". A pré-hibridação foi feita por 2 horas a $42{ }^{\circ} \mathrm{C}$ e para cada $\mathrm{cm}^{2}$ de membrana foram usados $0,1 \mathrm{ml}$ de solução de pré-hibridação, composta de formamida a 50\%, SSPE 6X, solução de "Denhardt" 5X, 1\% SDS, DNA de esperma de salmão a $20 \mu \mathrm{g} / \mathrm{ml}$ desnaturado por aquecimento em banho Maria a $70{ }^{\circ} \mathrm{C}$.

A hibridação foi feita de 10 a 18 h, a $42{ }^{\circ} \mathrm{C}$, e foram utilizados $100 \mathrm{ng}$ de sonda $\operatorname{Dm} 238$ para cada $1 \mathrm{ml}$ de solução de hibridação. A sonda foi desnaturada na própria solução de hibridação por aquecimento em banho Maria a $68{ }^{\circ} \mathrm{C}$. Para cada $\mathrm{cm}^{2}$ de membrana foram utilizados $0,1 \mathrm{ml}$ de solução de hibridação, cuja formulação é: dextrana-sulfato a $10 \%$, formamida a 50\%, SSPE 6X, solução de "Denhardt" 5X, 1\% SDS, DNA de esperma de salmão a $20 \mu \mathrm{g} / \mathrm{ml}$.

As temperaturas e concentrações das soluções utilizadas nas lavagens pós-hibridação foram realizadas em condições de alta estringência, recomendadas para hibridações DNADNA em que é prevista similaridade alta entre as seqüências da sonda e do DNA alvo (Sambrook, et al., 1989). Em cada lavagem, para cada $\mathrm{cm}^{2}$ de membrana foram usados 1,5 ml de solução de lavagem, conforme descrito a seguir: $1^{\mathrm{a}}$ e $2^{\mathrm{a}}$ lavagens, SSC $2 \mathrm{X}$ e SDS 0,1\% (temp. ambiente por $10 \mathrm{~min}) ; 3^{\mathrm{a}}$ e $4^{\mathrm{a}}$ lavagens, SSC $0,1 \mathrm{X}$ e SDS $0,1 \%\left(65^{\circ} \mathrm{C}\right.$ por $\left.20 \mathrm{~min}\right)$. 


\subsection{Micrografia do exocórion dos ovos}

Ovos das duas populações de $C x$. quinquefasciatus (Tabela 1) foram preparados para análise por microscopia eletrônica de varredura (MEV) conforme método modificado de Alencar, et al. (2005). Os ovos foram fixados com glutaraldeído a 2,5\% à temperatura de 4 ${ }^{\circ} \mathrm{C}$. Posteriormente foi feita a montagem do material em porta-amostras para MEV, utilizando fita adesiva dupla-face. O material foi então submetido ao recobrimento por ouro através de “sputtering”. Para a obtenção das imagens foi utilizado o microscópio eletrônico de varredura no Museu de Zoologia da Universidade de São Paulo.

A partir das imagens digitalizadas, medições dos tubérculos do exocórion dos ovos, como altura e densidade foram efetuadas. Para tal foi utilizado o "software" kS300 Zeiss para as medidas de altura e o "software" PowerPoint (Microsoft) para as medidas de densidade, com o qual foram feitos quadrados de tamanhos conhecidos em $\mu \mathrm{m}$ e contados quantos tubérculos couberam em cada quadrado, enquanto que o cálculo de relações e razões entre as medidas foram feitos com o auxílio do "software" Excel (Microsoft). As medidas obtidas (Tabelas 2 e 3 ) foram submetidas a análises estatísticas descritivas e comparativas com o auxílio do "software" Statistica 7.0 (StatSoft). Foram analisados 9 ovos do PET e 8 ovos de PARIQ (Tabela 1). 


\section{RESULTADOS}

\subsection{Coleta dos espécimes}

Os 6 eventos de coleta renderam cerca de 800 larvas, 600 ovos e 500 adultos de $C x$. quinquefasciatus. Outras espécies também foram coletadas: Ae. sp., Ae. scapularis, Cx. sp., Cx. chidestri, Cx. corniger, Cx. nigripalpus, An. sp. E Mansonia wilsoni, as quais foram armazenadas na coleção entomológica deste laboratório para futuros estudos.

Uma das espécies coletadas, Cx. corniger, a qual pode ser encontrada ocupando o mesmo nicho que $C x$. quinquefasciatus, também foi utilizada para estudos morfométricos. A morfometria geométrica permitiu uma nova diagnose para essas espécies baseada somente em asas. Esses dados foram publicados em formato de artigo científico, o qual encontra-se no Anexo C.

\subsection{Análises Morfométricas}

\subsubsection{Diagrama de grades}

Os diagramas alares da distribuição dos indivíduos ao longo da respectiva Variável Canônica possibilitaram comparar amostras pareadas das duas populações. As configurações alares geradas nas comparações intra e interpopulacionais das amostras do PET e PARIQ estão dispostas em histogramas e em diagramas de deformação em grades os quais estão aumentados em 3 vezes para melhor visualização da tendência do formato alar (Figuras 5-12).

Avaliações intrapopulacionais: comparando-se asas direitas e esquerdas, foi possível notar uma pequena assimetria bilateral em ambas populações. Em todas as análises realizadas tanto para machos quanto para fêmeas houve sobreposição quanto aos valores da VC, conforme ilustrado nas Figuras 6, 7, 9 e 10.

O dimorfismo sexual foi evidente, pois os indivíduos machos e fêmeas distribuem-se diferentemente nos valores negativos e positivos das VCs, fato observado tanto nas amostras do PET quanto nas de PARIQ. Nas amostras do PET, as fêmeas distribuem exclusivamente nos valores negativos e os machos nos valores positivos, enquanto que nas amostras de PARIQ ocorre o inverso, além de não haver sobreposição na distribuição dos sexos, conforme ilustrado nos histogramas das Figuras 5 e 8. 
Foi possível notar também, através dos diagramas de deformação, que tanto em PET quanto em PARIQ, as asas de machos são mais estreitas que as asas de fêmeas (Figuras 5 e 8). Os pontos que concentram a maior parte do dimorfismo sexual são: 1, 10, 11, 17 e 18 .

Na comparação interpopulacional, PET e PARIQ distinguiram-se moderadamente. Embora distinguíveis, foi possível notar que há sobreposição parcial das duas populações ao longo da $\mathrm{VC}$, o que é válido tanto para machos quanto para fêmeas, conforme ilustrado nos histogramas das Figuras 11 e 12. Os teste de reclassificação feito tanto para comparação de fêmeas quanto de machos entre as populações estão listado nas Tabelas 4 e 5 respectivamente.

\subsubsection{Análises de forma alar através das Variáveis Canônicas}

As comparações multivariadas de forma alar utilizando simultaneamente quatro grupos (machos direita, machos esquerda, fêmeas direita, fêmeas esquerda) geraram duas variáveis canônicas (VC1 e VC2). As VCs geradas nessas comparações, que foram realizadas para PET e PARIQ separadamente, estão ilustradas em gráficos de dispersão na Figura 13. Através do eixo da VC1 podemos distinguir as amostras de machos de amostras de fêmeas, o que não é possível ao longo do eixo da VC2, uma variável menos discriminante.

No gráfico das amostras do PET notamos que a área de dispersão das fêmeas é maior que a dos machos e que a assimetria bilateral em machos é um pouco maior do que em fêmeas, como confirmado pelas distâncias de Mahalanobis (Figura 14) (Tabela 6) geradas nesta mesma análise comparativa. As distâncias de Mahalanobis entre essas amostras foram de 1,23 para a dissimilaridade entre as asas esquerdas e direitas de fêmeas e de 1,52 entre asas de machos. Similarmente, no gráfico das amostras de PARIQ, a área de dispersão e a assimetria bilateral são mais acentuadas em machos do que em fêmeas, com valores de Distância de Mahalanobis 1,15 entre fêmeas e 3,38 entre machos.

$\mathrm{O}$ dimorfismo sexual foi mais acentuado que as assimetrias bilaterais. Na mesma matriz de dissimilaridades, os valores das distâncias de Mahalanobis para comparações entre sexos obtidos para amostras do PET variaram de 58,12 a 65,25 enquanto que para amostras de PARIQ variaram de 77,23 a 80,09. 


\subsubsection{Tamanhos de centróides}

Os tamanhos dos centróides alares de cada indivíduo das duas populações estão listados nas Tabelas 7 e 8. Descrições estatísticas da distribuição dos tamanhos de centróides, tais como médias, erros e desvios-padrão estão mostrados nas Figuras15 e 16.

Comparações intrapopulacionais entre asas esquerdas e direitas realizadas com teste estatístico não-paramétrico de Mann-Whitney ou teste t-paramétrico, aplicados para PET e PARIQ, revelaram assimetria bilateral não-significativa $(\mathrm{p}>0,05)$ em ambos os sexos para essas duas populações (Figura 16) (Tabelas 9 e 10).

Pudemos também observar que os tamanhos de centróides de fêmeas são estatisticamente maiores que os dos machos $(p<0,0001)$ (Tabela 11), sendo que os valores médios foram de 3,4 $\mathrm{mm}$ para fêmeas e 2,8 $\mathrm{mm}$ para machos do PET e 2,85 $\mathrm{mm}$ para fêmeas e 2,5 mm para machos de PARIQ. O dimorfismo sexual (de tamanho de centróide) é maior nos indivíduos do PET do que nos de PARIQ (Figura 15).

As comparações interpopulacionais, feitas com fêmeas e machos separadamente conforme ilustrado na Figura 15, mostraram uma grande e significativa diferença entre as duas populações $(p<0,0001)$ (Tabela 12), mais evidente nas fêmeas do que nos machos.

\subsection{Análise do DNA ribosômico}

O produto da extração de DNA de cada indivíduo resultou em uma banda de migração semelhante à de $30 \mathrm{~Kb}$ do marcador, e foi então submetido à clivagem com endonuclease. $\mathrm{A}$ hibridação feita com as amostras de DNA de machos do PET e PARIQ digerido com a endonuclease EcoRI, evidenciou 4 bandas de aproximadamente 10900 pb, 8000 pb, 5800 pb e 1300 pb. Esse padrão composto de 4 bandas foi homogêneo, com pequenas exceções, dentro de cada população e também entre as populações.

As bandas mais evidentes e presentes em quase todos os indivíduos foram as de 8000 pb, 5800 pb e 1300 pb (Figura 17). A banda de 10900 pb embora presente nas duas populações, não foi visível em todos os indivíduos. Réplicas deste experimento com amostras dessas populações resultaram em padrões de bandas semelhantes.

A hibridação feita com amostras de DNA de fêmeas e machos do PET e de PARIQ extraídos individualmente e em "pools" digerido com as endonucleases AluI e DraI não produziram banda visível, provavelmente por terem clivado o DNA em diversos fragmentos pequenos (Figura 18). A fragmentação já era imaginada quando analisamos o gel das 
amostras submetidas a essas endonucleases, pois a maior parte do DNA fragmentado migrou distâncias maiores na agarose. Comparando o gel dessas amostras com géis de outras percebese essa fragmentação (Figura 20).

A hibridação das amostras após as digestões por BamHI e HindIII evidenciaram uma banda de DNA altamente repetitivo visível no gel. Essa banda correspondeu a parte do DNAr. Aparentemente as bandas têm tamanhos semelhantes para essas duas últimas enzimas (Figura 19).

\subsection{Micrografia de ovos}

As imagens de micrografia eletrônica dos ovos de $C x$. quinquefasciatus das populações do PET e de PARIQ encontram-se na Figura 21. Na camada mesh-work (sensu Sahlén, 1990) do exocórion foi observada a presença de tubérculos coriônicos. As medidas de altura e densidade dos tubérculos coriônicos que cobrem a superfície dos ovos estão listadas respectivamente nas Tabelas 2 e 3. Quanto à altura, as médias obtidas foram: 1,30 $\mu \mathrm{m}$ para amostras do PET e 1,41 $\mu \mathrm{m}$ para amostras de PARIQ (Figura 22). O teste T não-pareado indicou diferença estatisticamente significativa entre PET e PARIQ quanto a essas alturas $(\mathrm{p}<0,05)$.

Em relação à densidade dos tubérculos, as médias foram 4,37 tubérculos $/ \mu \mathrm{m}^{2}$ para amostras do PET e 5,09 tubérculos/ $\mu \mathrm{m}^{2}$ para amostras de PARIQ (Figura 22). Embora as médias tenham sido semelhantes, na amostra de PARIQ a variância foi grande, com medidas entre 2,83 até 8,20 tubérculos $/ \mu \mathrm{m}^{2}$, enquanto que em PET os valores encontram-se entre 3,10 até 5,40 tubérculos $/ \mu \mathrm{m}^{2}$. 


\section{DISCUSSÃO}

As espécies coletadas no PET foram as mesmas descritas em outros trabalhos com amostras provenientes desse local, como as mencionadas em Urbinatti, et al. (2001). Os principais aspectos biológicos evidenciados pelas análises morfométricas foram: assimetria bilateral, dimorfismo sexual e diferenciação populacional. Interpretações desses aspectos são comentadas a seguir.

Um fato merece certa atenção: Tanto em PET, quanto em PARIQ existe ligeira assimetria alar de forma, mas não de tamanho, sendo essa assimetria mais evidente na população de PARIQ. Talvez a assimetria de forma, embora significativa do ponto de vista estatístico-morfométrico, não seja tão relevante a ponto de prejudicar o vôo ou outras funções alares. Como em culicídeos a assimetria bilateral também pode estar relacionada com pertubações ambientais como inseticidas ou outro stress (Sousa, et al., 2007), imaginou-se que os indivíduos de São Paulo tivessem mais assimetria por estarem inseridos em um ambiente mais poluído e modificado. Uma vez que essa previsão não se confirmou, é possível que a assimetria bilateral com diferentes intensidades nas populações seja resultado de fatores genético-ambientais ainda não avaliados.

O dimorfismo sexual alar já era esperado, pois já havia sido suspeitado por estudos taxonômicos tradicionais realizados com culicídeos (Lien, 1968). Este resultado está de acordo com outras observações feitas por diversos autores sobre as funções distintas que as asas podem assumir para ambos os sexos, sendo que machos podem usá-las na produção de sons de côrte sexual e fêmeas para vôos precisos durante busca de alimento, dispersão apetente e oviposição (Wekesa, et al., 1998; Forattini, 2002). O dimorfismo sexual mais pronunciado na população do PET, talvez seja resultado de fatores ambientais locais, distintos nessas áreas de coleta. Entretanto, as causas de tal fenômeno deverão ser melhor investigadas futuramente.

$\mathrm{Na}$ comparação das duas populações geograficamente distintas (PET e PARIQ), notamos que elas se comportam diferentemente uma da outra, como se não fossem um mesmo grupo panmítico. Isso se confirma para forma e tamanho, o que nos leva a crer que não há fluxo gênico entre essas populações.

Como não sabemos ao certo quais são as bases genéticas determinantes desses caracteres alares, essas comparações não são estimativa precisa de fluxo gênico, mas ainda assim é um indicativo válido de que existe alguma diferenciação. Há evidências de que o 
formato alar possui herança quantitativa, pois em um de seus trabalhos Jirakanjanakit, et al. (2008), verificou a característica herdável da forma alar em isolinhagens de Ae. aegypti através de sucessivas gerações. Já o tamanho alar, no entanto, pode estar relacionado à plasticidade devido a fatores ambientais como, por exemplo, densidade larval e quantidade de alimento disponível (Jirakanjanakit, et al., 2007).

Em suma, os resultados de morfometria alar podem significar diferenciação genética populacional, quando relacionados à forma alar ou uma plasticidade relacionada ao tipo de ambiente, ao se tratar do tamanho alar, já que as populações estudadas vivem sob diferentes condições ambientais, como observado em outros trabalhos já publicados (Jirakanjanakit, et al., 2008; Jirakanjanakit, et al., 2007; Jirakanjanakit e Dujardin, 2005; Dujardin, 2008).

Estatisticamente, as duas populações em questão são diferentes quanto à medida de altura dos tubérculos do exocórion dos ovos. A variação intraespecífica de alturas de tubérculos já foi reportada para Cx. quinquefasciatus por Sahlén (1990). Entretanto, a observação de Sahlén (1990) não avaliou mais de uma população, o que não permitiu interpretações acerca das variações geográficas desses caracteres. Como hipótese, é possível que a distinção aqui notada seja um indicativo de polimorfismos geográficos, o que se for confirmado conferirá ao caráter "altura de tubérculos coriônicos" utilidade em investigações biogeográficas.

A análise da densidade desses tubérculos teve um número amostral pequeno devido à dificuldade de captura das imagens no MEV propícias para observação desses caracteres. Por essa razão não foram feitos testes estatísticos para essa análise.

Não sabemos se os caracteres do exocórion de $C x$. quinquefasciatus poderão algum dia ter a relevância taxonômica dos caracteres exocoriônicos de Haemagogus, Aedes, Anopheles, gêneros nos quais várias espéceis diferem quanto à ultraestrutura e ornamentação do exocórion (Lounibos, et al., 1997; Forattini, et al., 1998; Sallum, et al., 2002; Alencar, et al., 2003). Espécies crípticas também têm sido diagnosticadas por micrografia do exocórion, como no caso de An. trinkae e An. dunhami, que diferem entre si quanto à ultraestrutura do exocórion (Lounibos, et al., 1998).

Como mencionado anteriormente, até mesmo populações podem ser distinguidas por tal abordagem, como é o caso o de Anopheles aconitus, o qual num estudo populacional, exibiu diferenças intraespecíficas quanto ao número de tubérculos do exocórion e a caracteres morfométricos dos ovos (Junkum, et al., 2004). Outros exemplos de variação populacional quanto à morfologia dos ovos são as espécies An. albimanus, An. vestitipennis e An. nuneztovari (Rodriguez, et al., 1992; Rodriguez, et al., 1999; Linley, et al., 1996). 
Não se pode descartar a hipótese de alguns desses caracteres do exocórion em $C X$. quinquefasciatus estarem sujeitos à plasticidade fenotípica, já que as bases genéticas determinantes da ornamentação exocoriônica não foram ainda bem eclucidadas. Nesses casos, o significado evolutivo e taxonômico dos caracteres seria inconclusivo.

Dentro de nosso conhecimento, essa é a primeira vez que algum grupo faz esse tipo de análise relacionada ao tamanho e densidade de tubérculos em ovos de Cx. quinquefasciatus. Esse tipo de análise parece ser promissor, porém, novos testes deverão ser feitos para confirmar o poder discriminatório dessa ferramenta para esse tipo de análise.

Quanto ao DNA ribossômico, o padrão de bandas não revelou polimorfismos fixos nas populações. É improvável que haja padrões de DNAr distintos desses observados, pois em geral essa porção do DNA é homogênea nos genoma e nos indivíduos de uma população devido aos mecanismos de evolução em concerto. No entanto, caso algum polimorfismo, viesse a ser detectado em $C x$. quinquefasciatus, poderia ser muito útil neste trabalho, a exemplo do que tem ocorrido em estudos filogenéticos (Miller, et al., 1996; Severini, et al., 1996; Navarro e Weaver, 2004) e taxonômicos de culicídeos (Debrunner-Vossbrinck, et al., 1996; Crabtree, et al., 1995).

Interpretando-se conjuntamente os presentes dados, pode-se dizer que os resultados de morfometria de asas e micrografia de ovos fornecem evidências de que o fluxo gênico interpopulacional é menor que o intrapopulacional no caso estudado. Além disso, os resultados de DNAr não indicam baixo fluxo gênico porém não asseguram existência de fluxo gênico importante. Essa aparente contradição entre aquilo que nos apontam os marcadores biológicos poderia ser explicada com a seguinte hipótese: intuitivamente, parece-nos parcimonioso admitir que essas populações estejam em processo incipiente de diferenciação genética e o fluxo gênico entre elas está sensivelmente reduzido. Neste caso o DNAr não teria acusado diferenciação populacional por supostamente ter uma taxa evolutiva mais lenta que a dos caracteres alares e de ovos. A idéia de que os caracteres biológicos evoluem em velocidades diferentes é atualmente bem aceita, como tem sido empiricamente verificado em diversos trabalhos (Sene, et al., 1988; Reinert, et al., 1997; Rocha, 2005).

Este trabalho e a presente interpretação estão compatíveis com outro estudo conduzido neste grupo de pesquisa sobre populações de $C x$. quinquefasciatus no Estado de São Paulo (Peruzin, 2009). Naquele estudo, populações provenientes de também de Pariquera-Açú e do rio Pinheiros (município de São Paulo), exibiram caracteres alares indicativos de isolamento geográfico, embora caracteres do DNAr não tenham tido resolução suficiente para detectar tal padrão. Naquela ocasião, o exocórion das amostras populacionais não foi analisado, portanto 
não é possível traçar um paralelo comparativo completo com a presente investigação. Ainda assim, o fato de os resultados de DNAr e morfometria alar terem sido semelhantes em dois estudos de desenho experimental assemelhado, reforça a verossimilhança da interpretação feita no presente trabalho.

A principal diferença entre o estudo aqui apresentado e o de Peruzin (2009) reside no ambiente amostrado no município de São Paulo. A população de Cx. quinquefasciatus do rio Pinheiros reproduz-se em água altamente poluída por resíduos industriais e recebe aplicações periódicas de inseticidas, e portanto vive em ambiente extremamente distinto daquele de Pariquera-Açú (Peruzin, 2009). Por outro lado, os mosquitos do município de São Paulo aqui analisados vieram do PET, um parque urbano cujo ambiente assemelha-se mais ao de Pariquera-Açú do que ao do rio Pinheiros. Assim sendo, no trabalho de Peruzin (2009), a divergência fenotípica interpopulacional poderia ter sido influenciada pelo ambiente extremamente hostil do rio Pinheiros, enquanto que neste trabalho, a divergência fenotípica pode ser atribuída com maior segurança à distância geográfica entre os municípios PariqueraAçú e São Paulo.

Nossos resultados atendem às sugestões de Dujardin (2008), um pesquisador com grande contribuição na entomologia médica. Esse autor (Dujardin, 2008) têm encorajado outros pesquisadores a utilizarem primeiramente ferramentas de biometria e morfometria na entomologia médica para detectar estruturação populacional, antes mesmo de recorrerem à custosa e tradicional genética populacional (microssatélites, isoenzimas, etc). Neste contexto ideológico, a continuação natural deste trabalho seria testar o fluxo alélico entre $C x$. quinquefasciatus de Pariquera-Açú e São Paulo (PET) com marcadores gênicos adequados para testar a hipótese de diferenciação genética aqui levantada. Investigações assim conduzidas poderão auxiliar o entendimento da transmissão de doenças veiculadas por esses insetos, os quais são importantes vetores de filarioses e arboviroses.

Uma aplicação imediata dos presentes resultados permitiria a identificação de indivíduos destes dois locais do Estado de São Paulo a partir das asas. Eventuais coletas que resultem em indivíduos mal-preservados, danificados ou de procedência duvidosa podem ser identificados a partir da análise discriminante dos caracteres alares, desde que pelo menos uma das asas esteja preservada. Isso permitirá determinar se a asa é proveniente de um macho ou fêmea, de uma população ou outra e presumivelmente, de Cx. quinquefasciatus ou outra espécie. 


\section{CONCLUSÕES}

1. A morfometria geométrica alar mostrou-se uma ferramenta útil na detecção de diferenciação populacional em $C x$. quinquefasciatus.

2. Há assimetria bilateral quanto à forma alar, e é mais evidente no ambiente com menos urbanização.

3. Há dimorfismo sexual de tamanho e forma alar.

4. Existe diferenciação populacional: Foram detectados polimorfismos nos caracteres alares e dos ovos.

5. Os polimorfismos têm correspondência geográfica, sendo específicos para cada região estudada (PET e PARIQ).

6. Os polimorfismos geográficos sugerem que o fluxo gênico entre as populações PET e PARIQ é reduzido, embora não haja evidências de que o fluxo gênico foi totalmente interrompido.

7. Possivelmente as populações estão em processo incipiente de diferenciação genética, acusada por caracteres alares e de ovos, porém ainda não pronunciadas no DNAr. 


\section{REFERÊNCIAS BIBLIOGRÁFICAS*}

Ahumada JA, Lapointe D, Samuel MD. Modeling the population dynamics of Culex quinquefasciatus (Diptera: Culicidae), along an elevational gradient in Hawaii. J Med Entomol. 2004; 41(6):1157-70.

Alencar J, Guimarães AE, Gil-Santana HR, Santos-Mallet JR. Scanning electron microscopy of eggs of Ochlerotatus (Protomacleaya) terrens Walker. J Am Mosq Control Assoc. 2005; 21(4):355-9.

Alencar J, Guimarães AE, Mello RP, Lopes CM, Degallier N, Santos-Mallet JR. Microscopia eletrônica de varredura de ovos de Haemagogus leucocelaenus (Diptera: Culicidae). Rev Saúde Pública. 2003; 37(5): 657-61.

Bates M, Roca-Garcia M. The laboratory studies of Saimiri Haemagogus cycle of jungle yellow fever. Am J Trop Med. 1945; 25:203-16.

Benedict MQ, Robinson AS. The first releases of transgenic mosquitoes: an argument for the sterile insect technique. Trends Parasitol. 2003; 19(8):349-55.

Bookstein FL. Morphometric tools for landmark dara: geometry and biology. Cambridge: Cambridge University press; 1997. 455 p.

Brogdon WG. Measurement of flight tone differences between female Aedes aegypti and A. albopictus (Diptera: Culicidae). J Med Entomol. 1994; 31(5):700-3.

Brogdon, WG. Measurement of flight tone differentiates among members of the Anopheles gambiae species complex (Diptera: Culicidae). J Med Entomol. 1998; 35(5):681-4.

Byrne K, Nichols RA. Culex pipiens in London Underground tunnels: differentiation between surface and subterranean populations. Heredity. 1999; 82(1):7-15.

Chaudhry S, Kohli R. Sequence analysis of mitochondrial 16S ribosomal RNA gene fragment in two populations of Culex quinquefasciatus Say (Culicidae : Diptera). Natl Acad Sci Lett. 2007; 30(1-2):55-60.

*De acordo com:

International Committee of Medical Journal Editors. Uniform requirements for manuscripts submitted to Biomedical Journal: sample references. Available from: http://www.icmje.org [2007 May 22]. 
Collins FH, Paskewitz SM. A review of the use of ribosomal DNA (rDNA) to differentiate among cryptic Anopheles species. Insect Mol Biol. 1996; 5(1): 1-9.

Consoli RAGB, Oliveira RL. Principais mosquitos de importância sanitária no Brasil. Rio de Janeiro: Fiocruz; 1994. 225 p.

Crabtree MB, Savage HM, Miller BR. Development of a species-diagnostic polymerase chain reaction assay for the identification of Culex vectors of St. Louis encephalitis virus based on interspecies sequence variation in ribosomal DNA spacers. Am J Trop Med Hyg. 1995; 53(1):105-9.

Debrunner-Vossbrinck BA, Vossbrinck CR, Vodkin MH, Novak RJ. Restriction analysis of the ribosomal DNA internal transcribed spacer region of Culex restuans and mosquitoes in the Culex pipiens complex. J Am Mosq Control Assoc. 1996; 12(3):477-82.

Donnelly MJ, Simard F, Lehmann T. Evolutionary studies of malaria vectors. Trends Parasitol. 2002; 18(2):75-80.

Dover G. Molecular drive: a cohesive mode of species evolution. Nature. 1982; 299: 111-117.

Dujardin JP. Morphometrics applied to medical entomology. Infect Genet Evol. 2008; 8(6):875-890.

Fonseca DM, Lapointe DA, Fleischer RC. Bottlenecks and multiple introductions: population genetics of the vector of avian malaria in Hawaii. Mol Ecol. 2000; 9(11): 1803- 1814.

Forattini OP. Culicidologia Médica. São Paulo: EDUSP; 2002. 864 p.

Forattini OP, Gomes AC, Natal D, Kakitani I, Marucci D. Preferências alimentares de mosquitos Culicidae no Vale do Ribeira, São Paulo, Brasil. Rev Saúde Pública. 1987a; 21:171-87.

Forattini OP, Gomes AC, Natal D, Kakitani I, Marucci D. Freqüência domiciliar e endofilia de mosquitos Culicidae no Vale do Ribeira, São Paulo, Brasil. Rev Saúde Pública. 1987b; 21:188-92.

Forattini OP, Gomes AC, Santos JLF, Kakitani I, Marucci D. Freqüência ao ambiente humano e dispersão de mosquitos Culicidae em área adjacente à mata atlântica primitiva da planície. Rev Saúde Pública. 1990; 24:101-7. 
Forattini OP, Sallum MAM, Bergo ES, Flores DC. Ultrastructure of eggs of Anopheles rondoni, Anopheles lutzi and Anopheles parvus, three species of the subgenerus Nyssorhynchus. J Am Mosq Control Assoc. 1998; 14(3): 256-65.

Futuyma DJ. Evolutionary Biology. Sunderland, Mass.: Sinauer Associates; 1997. 763 p.

Gentile G, Slotman M, Ketmaier V, Powell JR, Caccone A. Attempts to molecularly distinguish cryptic taxa in Anopheles gambiae s.s. Insect Mol Biol. 2001; 10: 25-32.

Gill SS, Cowles EA, Pietrantonio PV. The Mode of Action of Bacillus thuringiensis Endotoxins. Annu Rev Entomol. 1992; 37: 615-634.

Hayes J. Seasonal changes in population structure of Culex pipiens quinquefasciatus Say (Diptera: Culicidae): study of an isolated population. J Med Entomol. 1975; 12(2):167-78.

Hemingway J, Karunaratne SH. Mosquito carboxylesterases: a review of the molecular biology and biochemistry of a major insecticide resistance mechanism. Med Vet Entomol. 1998; 12(1):1-12.

Hillis DM, Dixon MT. Ribosomal DNA: molecular evolution and phylogenetic inference. Q Rev Biol. 1991; 66: 441-453. Review.

Jirakanjanakit N, Leemingsawat S, Dujardin JP. The geometry of the wing of Aedes (Stegomyia) aegypti in isofemale lines through successive generations. Infect Genet Evol. 2008; 8:414-421.

Jirakanjanakit N, Dujardim JP. Discrimination of Aedes aegypti (diptera: culicidae) laboratory lines based on wing geometry. Southeast Asian J Trop Med Public Health. 2005; 36: 858-861.

Jirakanjanakit NS, Leemingsawat S, Thongrungkiat C, Apiwathnasorn S, Singhaniyom C, Bellec, Dujardin JP. Influence of larval density or food variation on the geometry of the wing of Aedes (Stegomyia) aegypti. Trop Med Int Health. 2007; 12(11): 1354-1360.

Jowett T. Preparation of Nucleic Acids. In: Roberts DB, editor. Drosophila, a practical approach. Oxford: Oxford University Press; 1986. 389 p.

Junkum A, Jitpakdi A, Komalamisra N, Jariyapan N, Somboon P, Bates PA, Choochote W. Comparative morphometry and morphology of Anopheles aconitus Form B and C eggs under scanning electron microscope. Rev Inst Med Trop. 2004; 46(5): 257-262. 
Kovats RS. El Nino and human health. Bull World Health Organ. 2000; 78( 9): 1127-35.

Labbé P, Berticat C, Berthomieu A, Unal S, Bernard C, Weill M, Lenormand T. Forty years of erratic insecticide resistance evolution in the mosquito Culex pipiens. PLoS Genet. 2007; 3(11): 205.

Laporta GZ, Sallum MA. Density and survival rate of Culex quinquefasciatus at Parque Ecológico do Tietê, São Paulo, Brazil. J Am Mosq Control Assoc. 2008; 24(1):21-7.

Laporta GZ, Urbinatti PR, Natal D. Aspectos ecológicos da população de Culex quinquefasciatus Say (Diptera, Culicidae) em abrigos situados no Parque Ecológico do Tietê, São Paulo, SP. Rev Bras Entomol. 2006; 50(1): 125- 27.

Lenormand T, Raymond M. Analysis of Clines with Variable Selection and Variable Migration. Am Nat. 2000; 155(1):70-82.

Lien JC. New Species of Mosquitoes from Taiwan (Diptera : Culicidae) Part V. Three New Subspecies of Aedes and Seven New Species of Culex. Trop Med. 1968; 10(4):217-62.

Linley JR, Lounibos LP, Conn J, Duzak D, Nishimura N. A description and morphometric comparison of eggs from eight geographic populations of the south American malaria vector Anopheles (Nyssorhynchus) nuneztovari (Diptera: Culicidae). J Am Mosq Control Assoc. 1996; 12(2): 275-292.

Lounibos LP, Duzak D, Linley JR. Comparative egg morphology of six species of the Albimanus section of Anopheles (Nyssorhynchus) (Diptera: Culicidae). J Med Entomol. 1997; 34(2): 136-155.

Lounibos LP, Wilkerson RC, Conn JE, Hribar LJ, Fritz GN, Danoff-Burg JA. Morphological, molecular, and chromosomal discrimination of cryptic Anopheles (Nyssorhynchus) (Diptera: Culicidae) from South America. J Med Entomol. 1998; 35(5):830-8.

Luna EJA, Pereira LE, Souza RP. Encefalite do Nilo Ocidental, nossa próxima epidemia? Epidemiol Serv Saúde (Brasília). 2003; 12(1):7-19.

Mandal SK, Ghosh A, Bhattacharjee I, Chandra G. Biocontrol efficiency of odonate nymphs against larvae of the mosquito, Culex quinquefasciatus Say, 1823. Acta Trop. 2008; 106(2):109-14. 
Manguin S, Wilkerson RC, Conn JE, Rubio-Palis Y, Danoff-Burg JA, Roberts DR. Population structure of the primary malaria vector in South America, Anopheles darlingi, using isozyme, random amplified polymorphic DNA, internal transcribed spacer 2, and morphologic markers. Am J Trop Med Hyg. 1999 ; 60(3):364-76.

Marrelli MT, Floeter-Winter LM, Malafronte RS, Tadei WP, Flores-Mendoza C, LourençoDe-Oliveira R, Marinotti O. Amazonian malaria vector anopheline relationships interpreted from ITS2 rDNA sequences. Med Vet Entomol. 2005; 19:208-218.

Marrelli MT, Malafronte RS, Flores-Mendoza C, Lourenço-De-Oliveira R, Kloetzel JK, Marinotti O. Sequence analysis of the second internal transcribed spacer (ITS2) of 23 ribosomal DNA in Anopheles oswaldoi (Diptera: Culicidae). J Med Entomol. 1999; 36:679684.

Marrelli MT, Moreira CK, Kelly D, Alphey L, Jacobs-Lorena M. Mosquito transgenesis: what is the fitness cost? Trends Parasitol. 2006; 22: 197-202.

McLain DK, Collins FH. Structure of rDNA in the mosquito Anopheles gambiae and rDNA sequence variation within and between species of the A. gambiae complex. Heredity. 1989; 62:233-42.

Miller BR, Crabtree MB, Savage HM. Phylogeny of fourteen Culex mosquito species, including the Culex pipiens complex, inferred from the internal transcribed spacers of ribosomal DNA. Insect Mol Biol. 1996; 5(2):93-107.

Monteiro LR, Reis SF. Princípios de morfometria geométrica. Ribeirão Preto: Holos; 1999. 189 p.

Moratore C, Suesdek L. Novos caracteres diagnósticos para mosquitos de interesse médico: Culex quinquefasciatus e Culex corniger (Diptera; Culicidae). Rev Univap. 2008; 15.

Mouchet J, Carnevale P. Impact des transformations de l'environnement sur les maladies à transmission vectorielle. Cahiers Santé. 1997; 7:263-269.

Navarro JC, Weaver SC. Molecular phylogeny of the Vomerifer and Pedroi Groups in the Spissipes Section of the subgenus Culex (Melanoconion). J Med Entomol. 2004; 41(4):57581.

Nayar JK, Knight JW, Munstermann LE. Temporal and geographic genetic variation in Culex pipiens quinquefasciatus (Diptera: Culicidae). J Med Entomol. 2003; 40(6):882-9. 
Pauvolid-Corrêa A, Varella RB. Aspectos epidemiológicos da Febre do Oeste do Nilo. Rev Bras Epidemiol. 2008; 11(3):463- 72.

Peruzin MCJ. Análises comparativas populacionais de Culex quinquefasciatus em dois locais do Estado de São Paulo [Dissertação]. São Paulo: Instituto de Biociências. Universidade de São Paulo; 2009. 96 p.

Powell JR, Tabachnick WJ, Arnold J. Genetics and the origin of a vector population: Aedes aegypti, a case study. Science. 1980; 208(4450):1385-7.

Reinert JF. List of species described in the egg stage of tribe Aedini (Diptera: Culicidae) with their literature citations. J Am Mosq Control Assoc. 2005; 21(3):252-62.

Reinert JF, Kaiser PE, Seawright JA. Analysis of the Anopheles (Anopheles) quadrimaculatus complex of sibling species (Diptera: Culicidae) using morphological, cytological, molecular, genetic, biochemical, and ecological techniques in an integrated approach. J Am Mosq Control Assoc. 1997; 13:1-102.

Reisen WK, Lothrop HD, Wheeler SS, Kennsington M, Gutierrez A, Fang Y, Garcia S, Lothrop B. Persistent West Nile virus transmission and the apparent displacement st. louis encephalitis virus in southeastern California, 2003-2006. J Med Entomol. 2008; 45(3):494508.

Rey L. Parasitologia. $3^{\text {nd }}$ ed. Rio de Janeiro: Guanabara Koogan; 2001. 856 p.

Ridley M. Evolution. Boston: Blackwell Scientific; 2003. 768 p.

Rocha LS. Caracterização de populações de Anastrepha sororcula Zucchi 1979 (Diptera: Tephritidae) por análises cromossômicas, morfométricas e moleculares [Tese]. São Paulo: Instituto de Biociências. Universidade de São Paulo; 2005. 127 p.

Roderick GK. Geographic structure of insect populations: gene flow, phylogeography, and their uses. Annu Rev Entomol. 1996; 41:325-352.

Rodriguez MH, Chaves B, Hernandez-Avila JE, Orozco A, Arredondo-Jimenez JI. Description and morphometric analysis of the eggs of Anopheles (Anopheles) vestitipennis (Diptera: Culicidae) from Southern Mexico. J Med Entomol. 1999; 36(1):78-87. 
Rodriguez MH, Chavez B, Orozco A, Loyola EG, Martinez-Palomo A. Scanning electron microscopic observations of Anopheles albimanus (Diptera: Culicidae) eggs. J Med Entomol. 1992; 29:400-6.

Rohlf FJ. Relative warp analysis and example of its application to mosquito wings. In: Marcus LF, Bello E, Garcia-Valdcasas, editors. Contributions to morphometrics. Madrid: Museo Nacional de Ciencias Naturales; 1993. p. 135-159. Monografia.

Rohlf FJ. TpsRelw, relative warps analysis [Computer program]. Version 1.36. Department of Ecology and Evolution, State University of New York. Stony Brook; 2003a.

Rohlf FJ. TpsRegr, shape regression [Computer program]. Version 1.28. Department of Ecology and Evolution, State University of New York. Stony Brook; 2003b.

Rohlf FJ. TpsUtil, file utility program [Computer program]. Version 1.26. Department of Ecology and Evolution, State University of New York. Stony Brook; 2004.

Rohlf FJ. TpsDig, digitize landmarks and outlines [Computer program]. Version 2.05. Department of Ecology and Evolution, State University of New York. Stony Brook; 2005.

Rosa-Freitas MG, Lourenco-de-Oliveira R, de Carvalho-Pinto CJ, Flores-Mendoza C, Silvado-Nascimento TF. Anopheline species complexes in Brazil. Current knowledge of those 24 related to malaria transmission Source. Mem Inst Oswaldo Cruz. 1998; 93(5):651-5.

Rosen L, Shroyer DA, Tesh RB, Freier JE, Lien JC. Transovarial transmission of dengue viruses by mosquitoes: Aedes albopictus and Aedes aegypti. Am J Trop Med Hyg. 1983; 32(5):1108-19.

Sahlén G. Egg Raft Adhesion and Chorion Structure in Culex pipiens L. (Diptera: culicidae). Int J Insect Morphol \& Embryol. 1990; 19(5/6):307-14.

Sahlen G. Eggshell ultrastructure in four mosquito genera (Diptera, culicidae). J Am Mosq Control Assoc. 1996; 12 (2 Pt 1):263-70.

Sallum MAM, Bergo ES, Forattini OP, Flores DC. The eggs of Anopheles galvaoi and Anopheles evansae, two species of the subgenus Nyssorhynchus (Diptera: Culicidae). J Am Mosq Control Assoc. 2002; 18(1):10-5.

Sambrook J, Fritsch EF, Maniatis T. Molecular cloning: A Laboratory manual. $2^{\text {nd }}$ ed. New York: Cold Spring Harbor Laboratory; 1989. 1659 p. 
Schachter-Broide J, Dujardin JP, Kitron U, Gurtler RE. Spatial structuring of Triatoma infestans (Hemiptera, Reduviidae) populations from northwestern Argentina using wing geometric morphometry. J Med Entomol. 2004; 41(4):643-9.

Sene FM, Pereira MAQR, Vilela CR. Contrasting Patterns of Differentiation Inferred from Traditional Genetic Markers in the Process of Speciation. Pac Sci. 1988; 42:81-88.

Severini C, Silvestrini F, Mancini P, La Rosa G, Marinucci M. Sequence and secondary structure of the rDNA second internal transcribed spacer in the sibling species Culex pipiens L. and Cx. quinquefasciatus Say (Diptera: Culicidae). Insect Mol Biol. 1996 ; 5(3):181-6.

Service M. Medical Entomology for Students. $3^{\text {rd }}$ ed. Liverpool: School of Tropical Medicine; 2004. 302 p.

Soumaré ML, Ndiaye M. Ultrastructural studies of mosquito ovogenesis. Tissue and Cell. 2005; 37:117-24.

Souza JMG, Gouveia M, Perondini ALP, Selivon D. Asymmetry of frontal bristles and postocular setae in species and hybrids of the Anastrepha fraterculus complex (Diptera: Tephritidae). Gen Mol Biol. 2007; 30:145-151.

Sperança MA, Capurro ML. Perspectives in the control of infectious diseases by transgenic mosquitoes in the post-genomic era: a review. Mem Inst Oswaldo Cruz. 2007; 102 (4): 425433.

StatSoft, Inc. STATISTICA for Windows [Computer program manual]. Tulsa, OK: StatSoft, Inc; 2004. Available from: http://www.statsoft.com [2009 Apr 8].

Taipe-Lagos CB, Natal D. Abundância de culicídeos em área metropolitana preservada e suas implicações epidemiológicas. Rev Saúde Pública. 2003; 37(3):275-9.

Tautz D, Hancock JM, Webb DA, Tautz C, Dover GA. Complete sequences of the rRNA genes of Drosophila melanogaster. Mol Biol Evol. 1988; 5:366-76.

Urbinatti PR, Sendacz S, Natal D. Imaturos de mosquitos (Diptera: Culicidae) em parque de área metropolitana aberto à visitação pública. Rev Saúde Pública. 2001; 35(5):461-6. 
Wekesa JW, Brogdon WG, Hawley WA, Besansky NJ. Flight tone of field collected populations of Anopheles gambiae and An. arabiensis (Diptera: Culicidae). Physiol Entomol. 1998; 23(3):289-94.

Wirth MC, Georghiou GP. Selection and characterization of temephos resistance in a population of Aedes aegypti from Tortola, British Virgin Islands. J Am Mosq Control Assoc. 1999; 15(3):315-20.

Yebakima A, Marquine M, Rosine J, Yp-Tcha MM, Pasteur N. Evolution of Resistance Under Insecticide Selection Pressure in Culex pipiens quinquefasciatus (Diptera, Culicidae) from Martinique. J Med Entomol. 2004; 41(4):718-25. 
ANEXO A - Figuras 

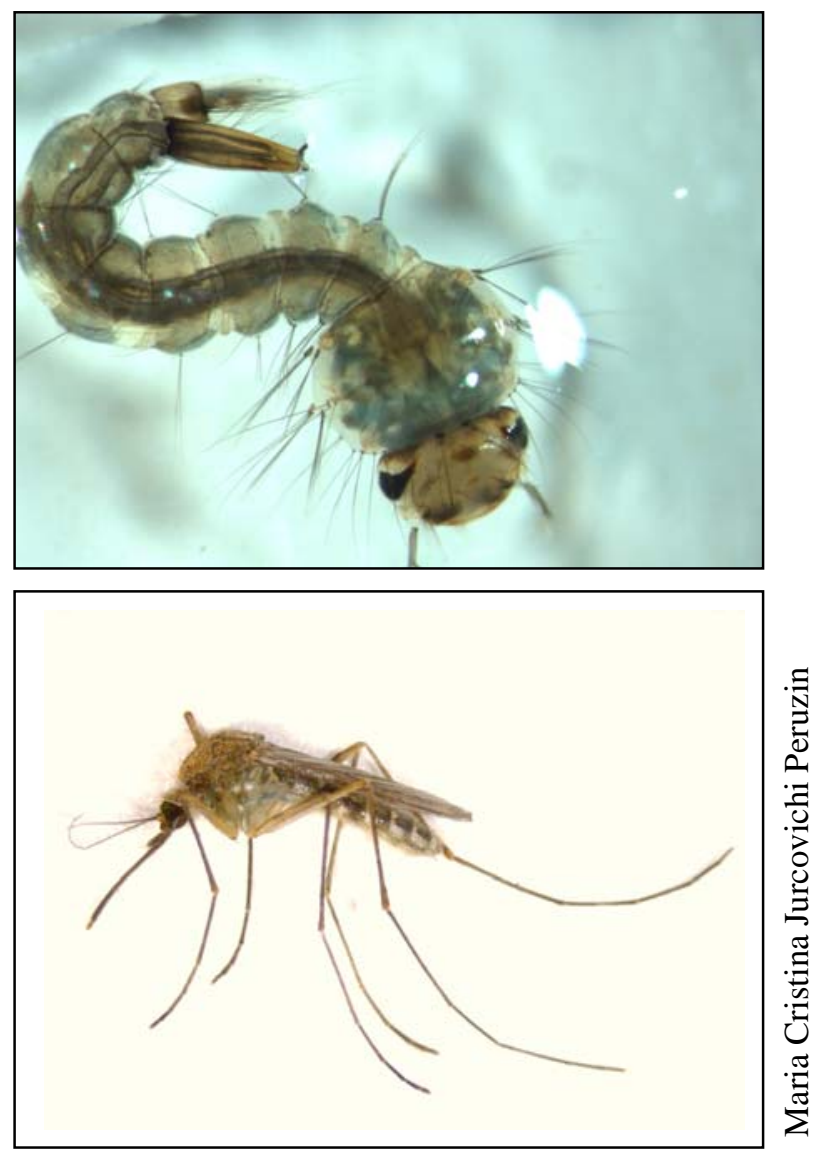

Figura A.1- Dois estágios de vida de Culex quinquefasciatus. Acima forma imatura (larva de $4^{\circ}$ instar) e abaixo fêmea adulta. 


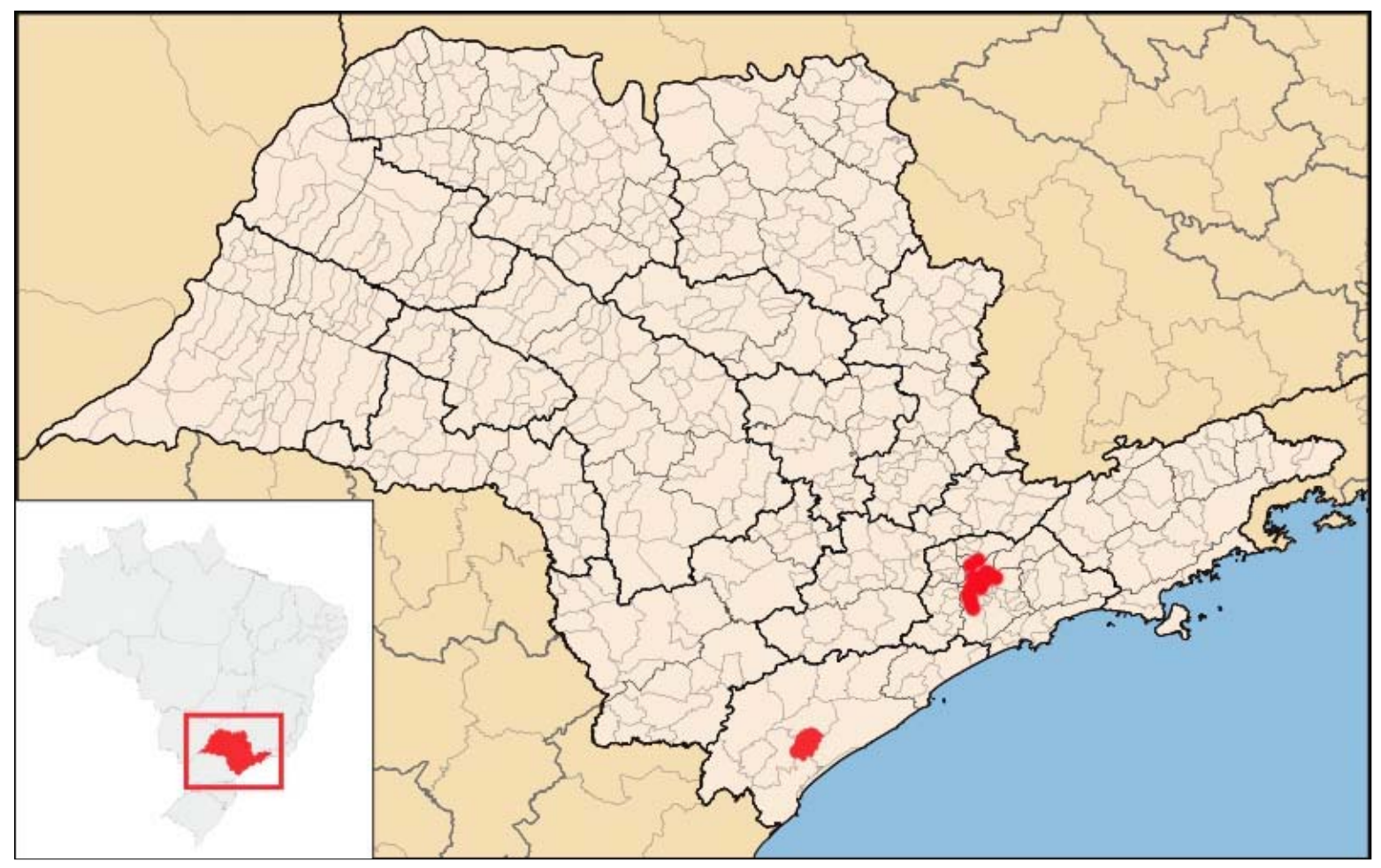

Figura A.2- Mapa do estado de São Paulo. As cidades de Pariquera-Açu e São Paulo estão destacadas em vermelho. A localização do estado no país está indicada no canto inferior esquerdo da figura. Modificado de: http://www.igc.sp.gov.br/ 

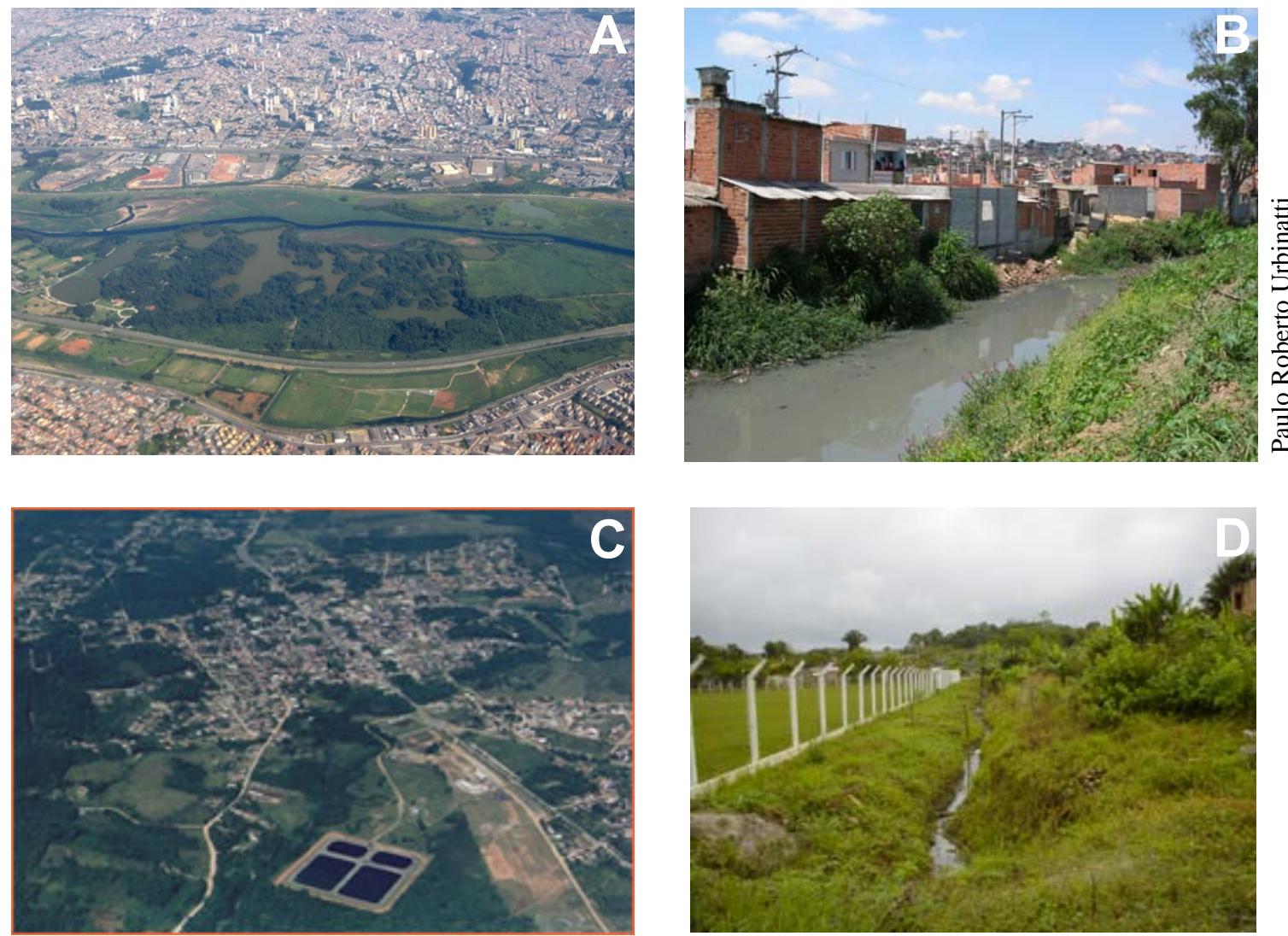

Figura A.3 - Imagens dos locais de coleta. Acima, imagens do PET: A- Foto aérea do Parque e arredores (http://www.panoramio.com/photo/6853319). B- Imagem do córrego de cicunvalação "Rio Negrinho", onde há intensa proliferação de imaturos de $C x$. quinquefasciatus. Abaixo imagens de Pariquera-Açu: C- Foto aérea da cidade (http://www.pariquera.com.br). D- Imagem capturada de uma vala onde são lançados esgotos domésticos, local típico de reprodução de $C x$. quinquefasciatus (http://www.cprm.gov.br/ gestao/ppga_valedoribeira). 

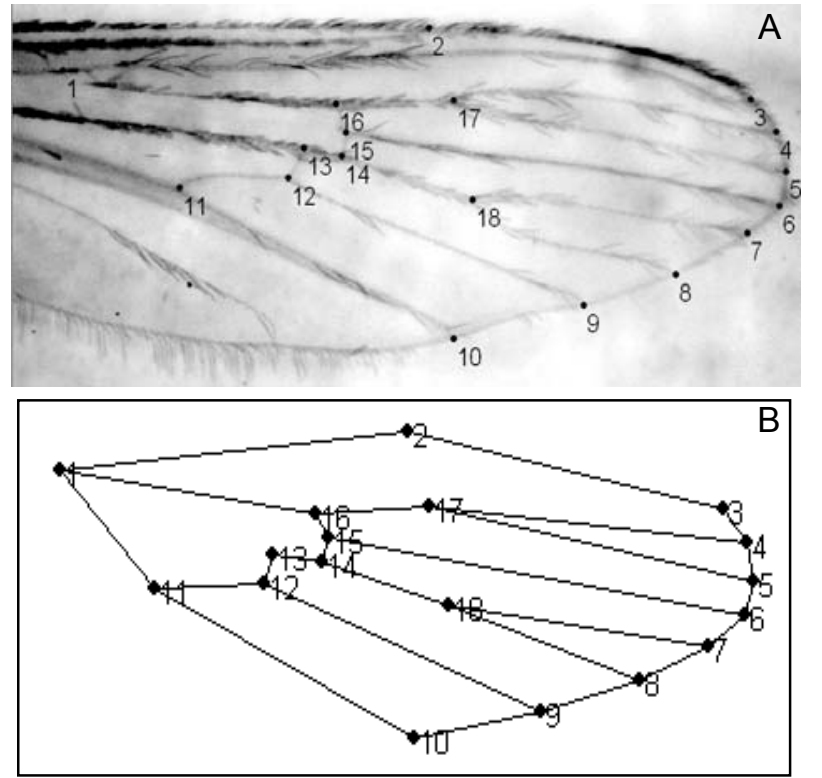

Figura A.4- Asa e consenso alar de $\boldsymbol{C x}$. quinquefasciatus. (A) Asa com os pontos anatômicos. (B) Representação gráfica do consenso alar formado pelos 18 pontos anatômicos ligados por linhas para facilitar a visualização. 
Fêmeas/Machos PET

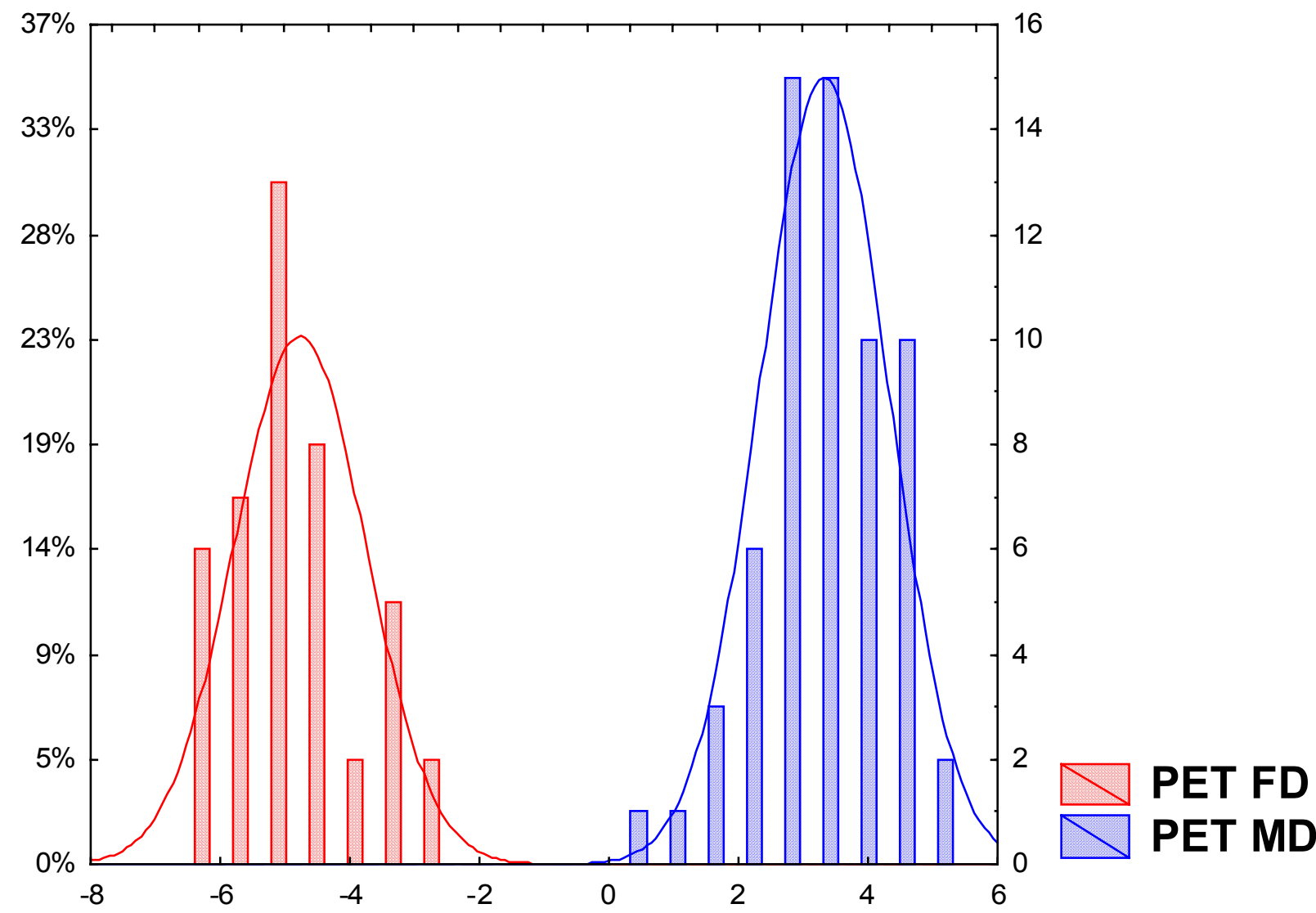

Diagrama alar - extremo negativo

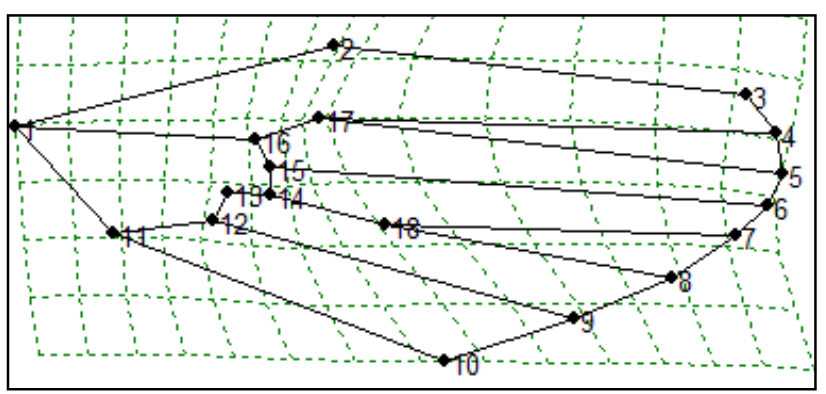

Diagrama alar - extremo positivo

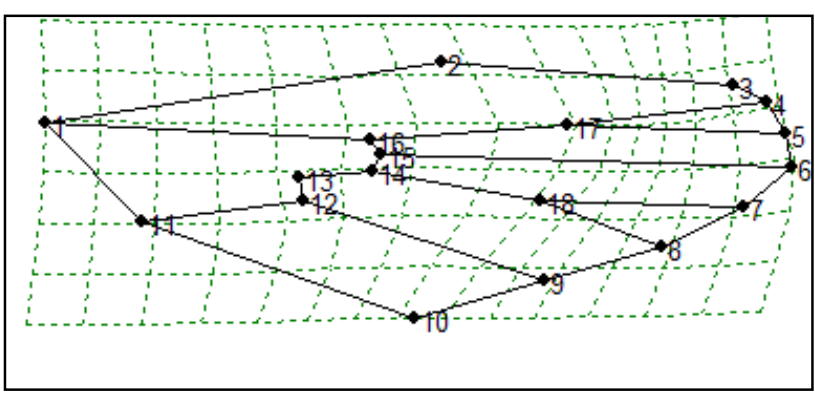

Figura A.5- Dimorfismo sexual na população do PET - Formato alar. Histograma de distribuição dos indivíduos ao longo da VC resultante da comparação entre fêmeas e machos do PET (valores VC no eixo X, número de indivíduos em cada categoria no eixo Y). Os valores aproximam-se da distribuição normal, conforme ilustrado pela curva Gaussiana hipotética. Notar que não há sobreposição entre as duas amostras, as asas das fêmeas distribuem no eixo negativo e dos machos no eixo positivo. Abaixo, os respectivos diagramas de deformação obtidos a partir da regressão dos valores da variável canônica, sobre os componentes de forma. O diagrama à esquerda tem fêmeas como referencial-alvo, enquanto o da direita tem machos como referencial-alvo. 
Fêmeas PET

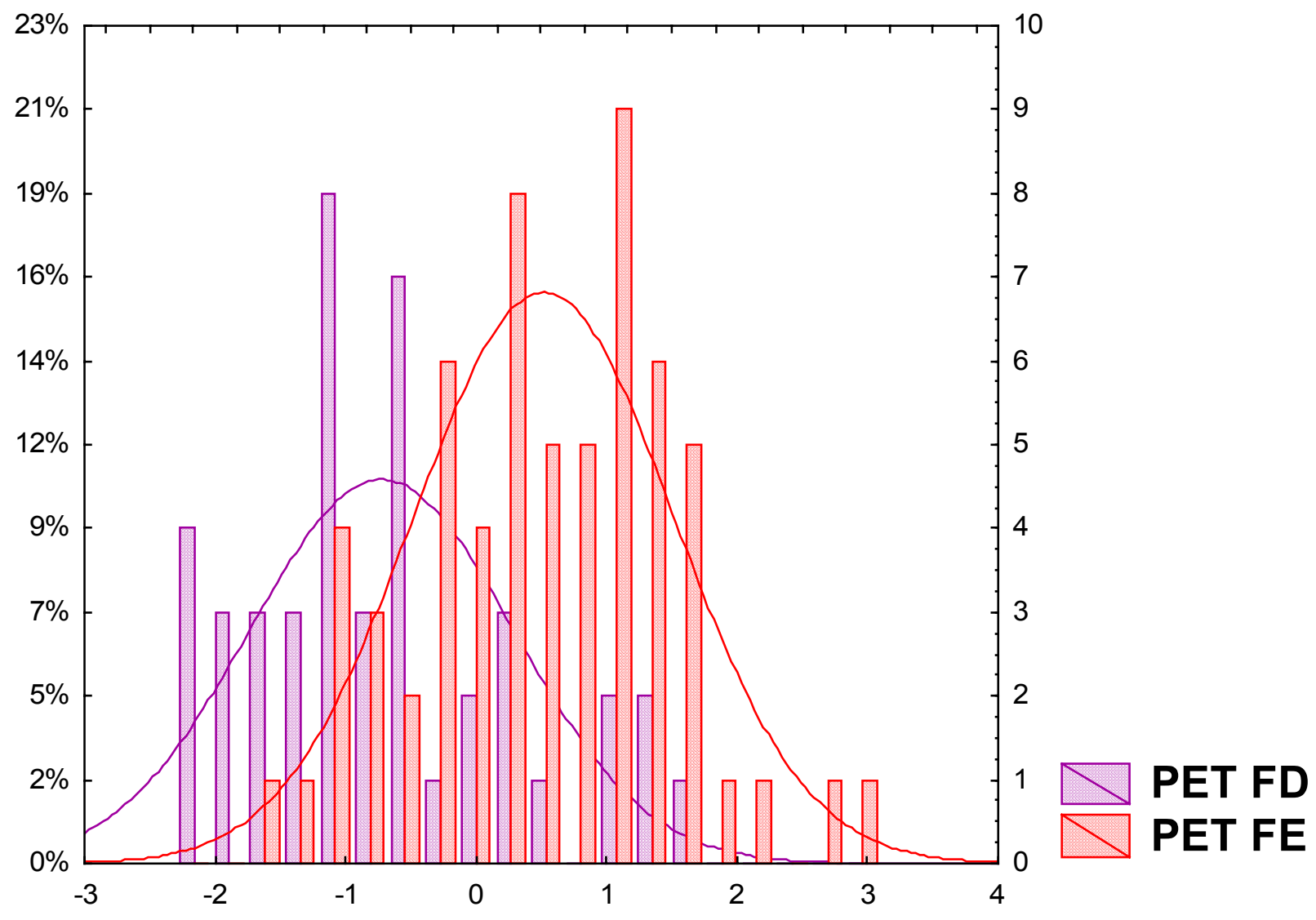

Diagrama de grades - extremo negativo

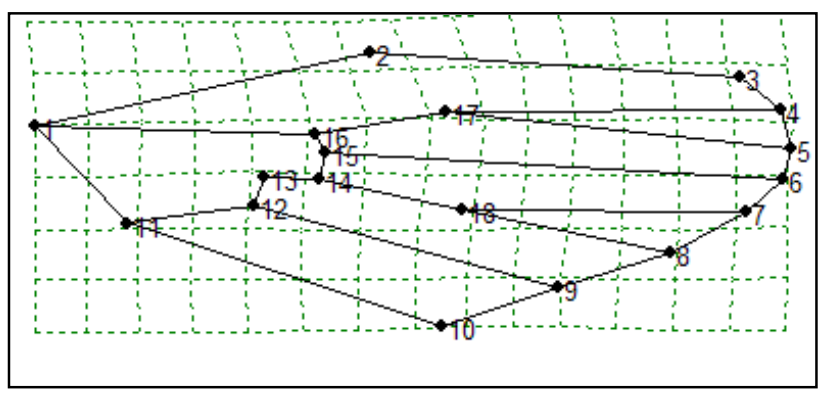

Diagrama de grades - extremo positivo

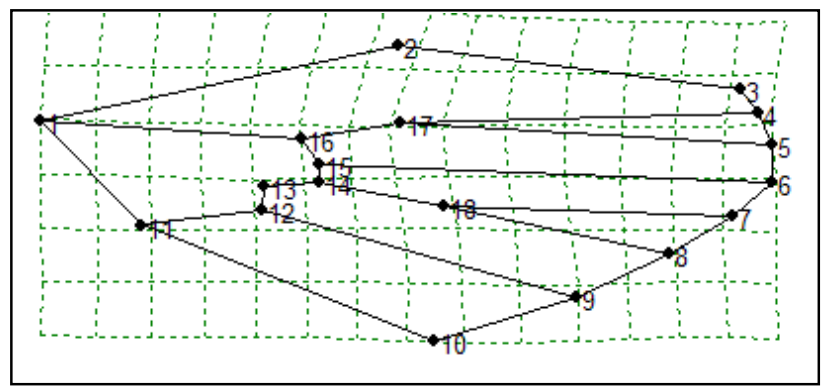

Figura A.6- Assimetria bilateral na população de fêmeas do PET - Formato alar. Histograma de distribuição dos indivíduos ao longo da VC resultante da comparação entre asas direitas e esquerdas de fêmeas do PET. Notar que há sobreposição entre as duas amostras. Abaixo, os respectivos diagramas de deformação. O diagrama à esquerda evidencia o extremo negativo, enquanto o da direita evidencia o extremo positivo. 
Machos PET

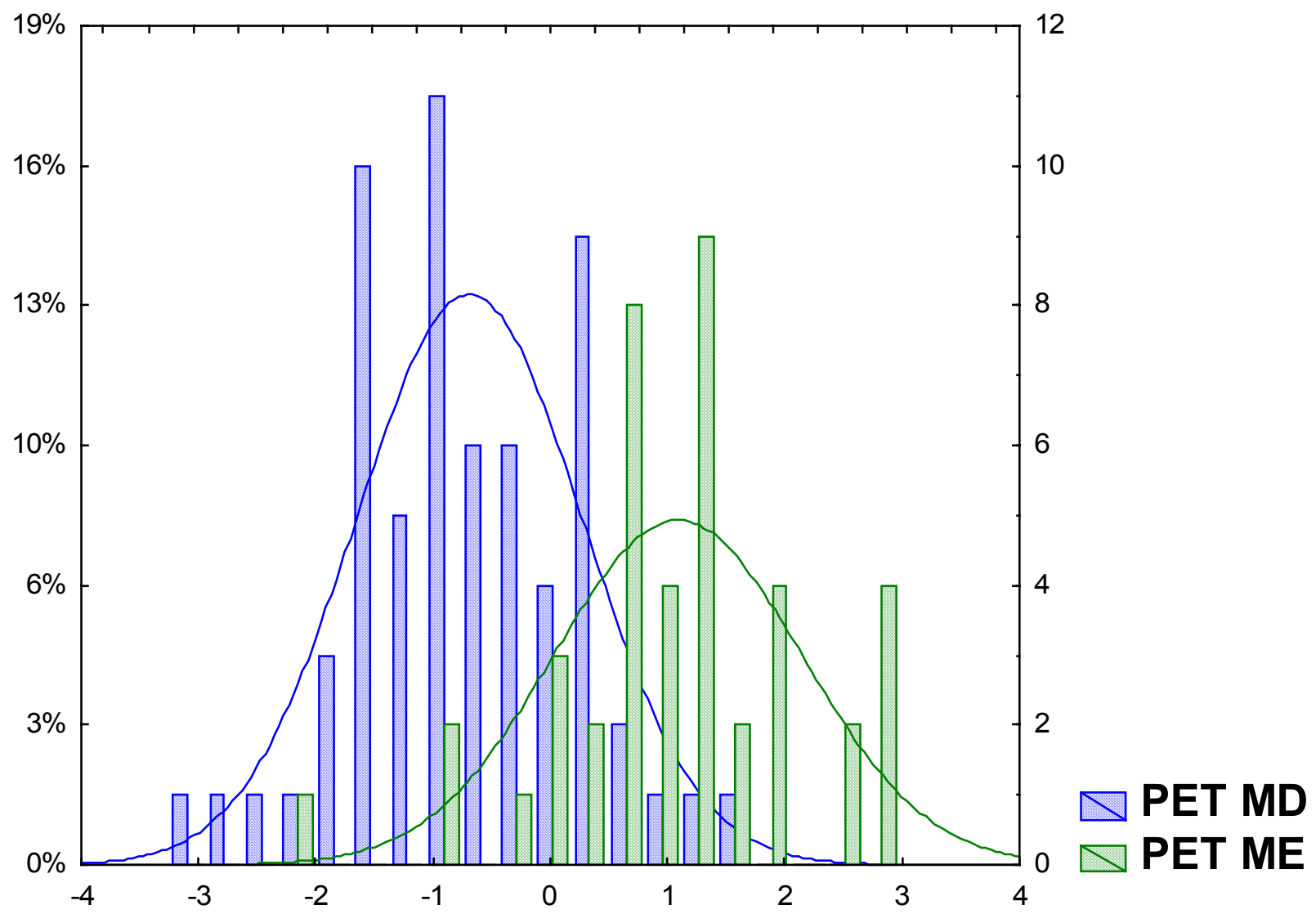

Diagrama de grades - extremo negativo

Diagrama de grades - extremo positivo
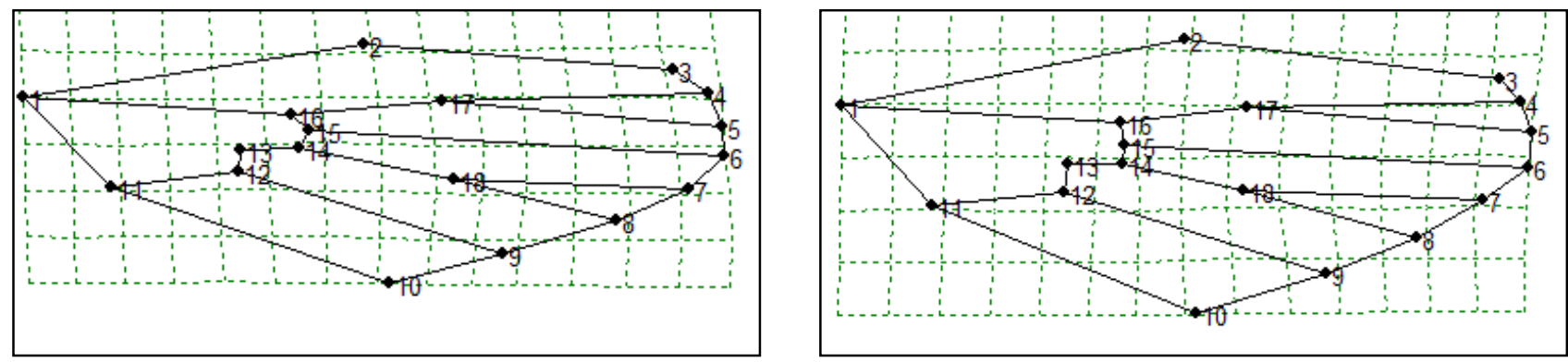

Figura A.7- Assimetria bilateral na população de machos do PET - Formato alar. Histograma de distribuição dos indivíduos ao longo da VC resultante da comparação entre asas direitas e esquerdas de machos do PET. Notar que há sobreposição entre as duas amostras. Abaixo, os respectivos diagramas de deformação. O diagrama à esquerda evidencia o extremo negativo, enquanto o da direita evidencia o extremo positivo. 
Fêmeas/Machos PARIQ.

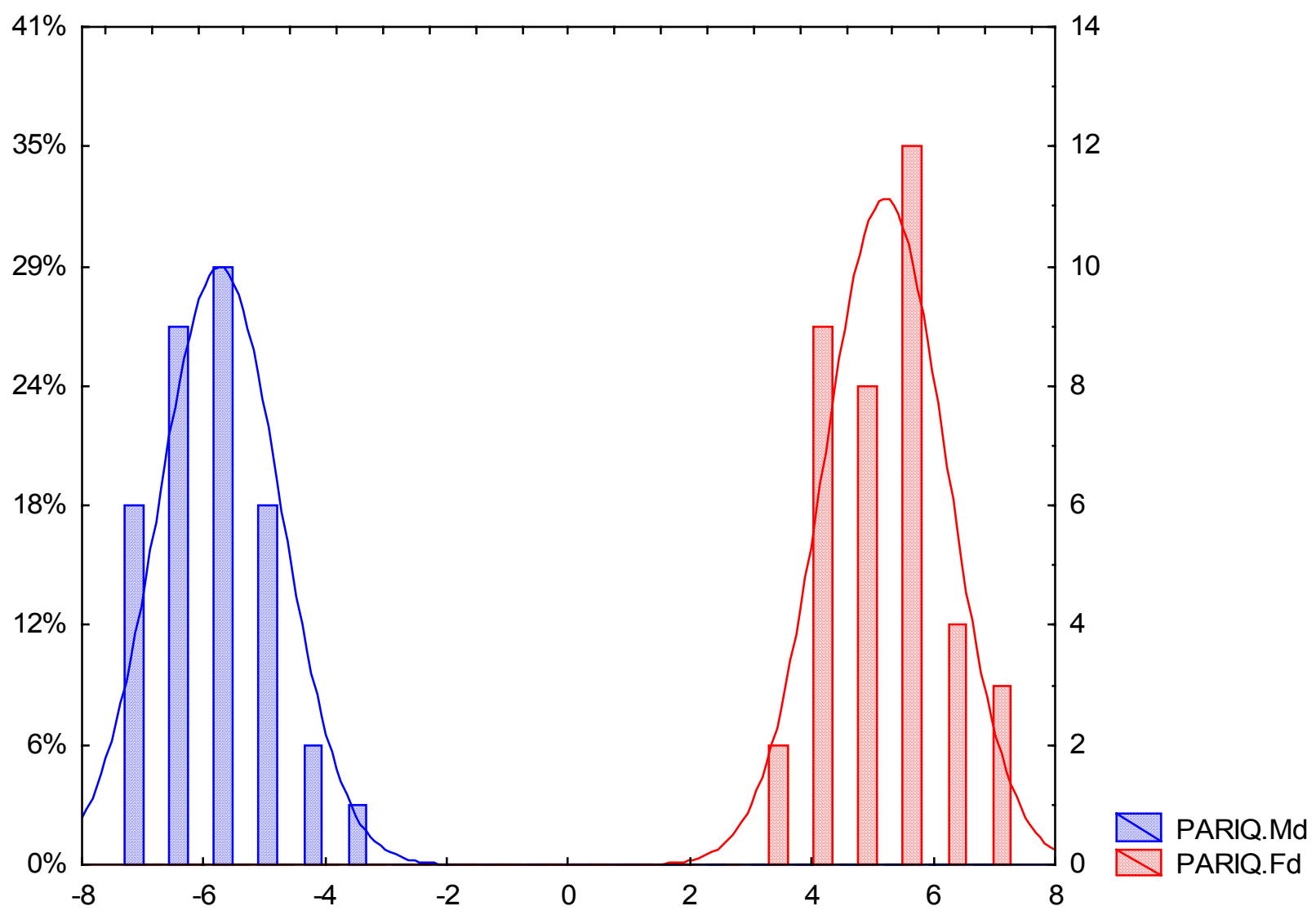

Diagrama de grades - extremo negativo

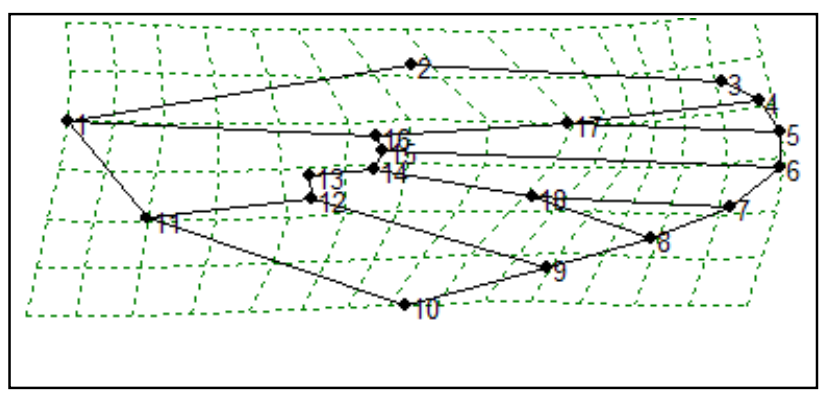

Diagrama de grades - extremo positivo

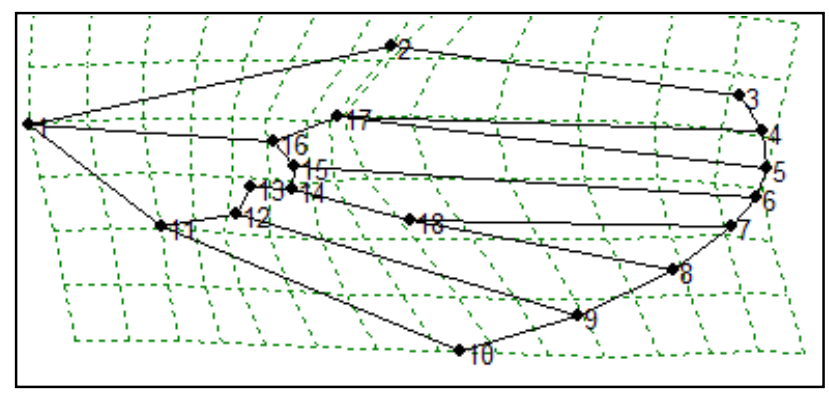

Figura A.8- Dimorfismo sexual na população de PARIQ - Formato alar. Histograma de distribuição dos indivíduos ao longo da VC resultante da comparação entre asas direitas de fêmeas e machos de PARIQ. Notar que não há sobreposição entre as duas amostras, as asas de fêmeas estão distribuídas no eixo positivo e as de machos no eixo negativo. Abaixo, os respectivos diagramas de deformação. O diagrama à direita tem fêmeas como referencial-alvo, enquanto o da esquerda tem machos como referencial-alvo. 


\section{Fêmeas PARIQ.}

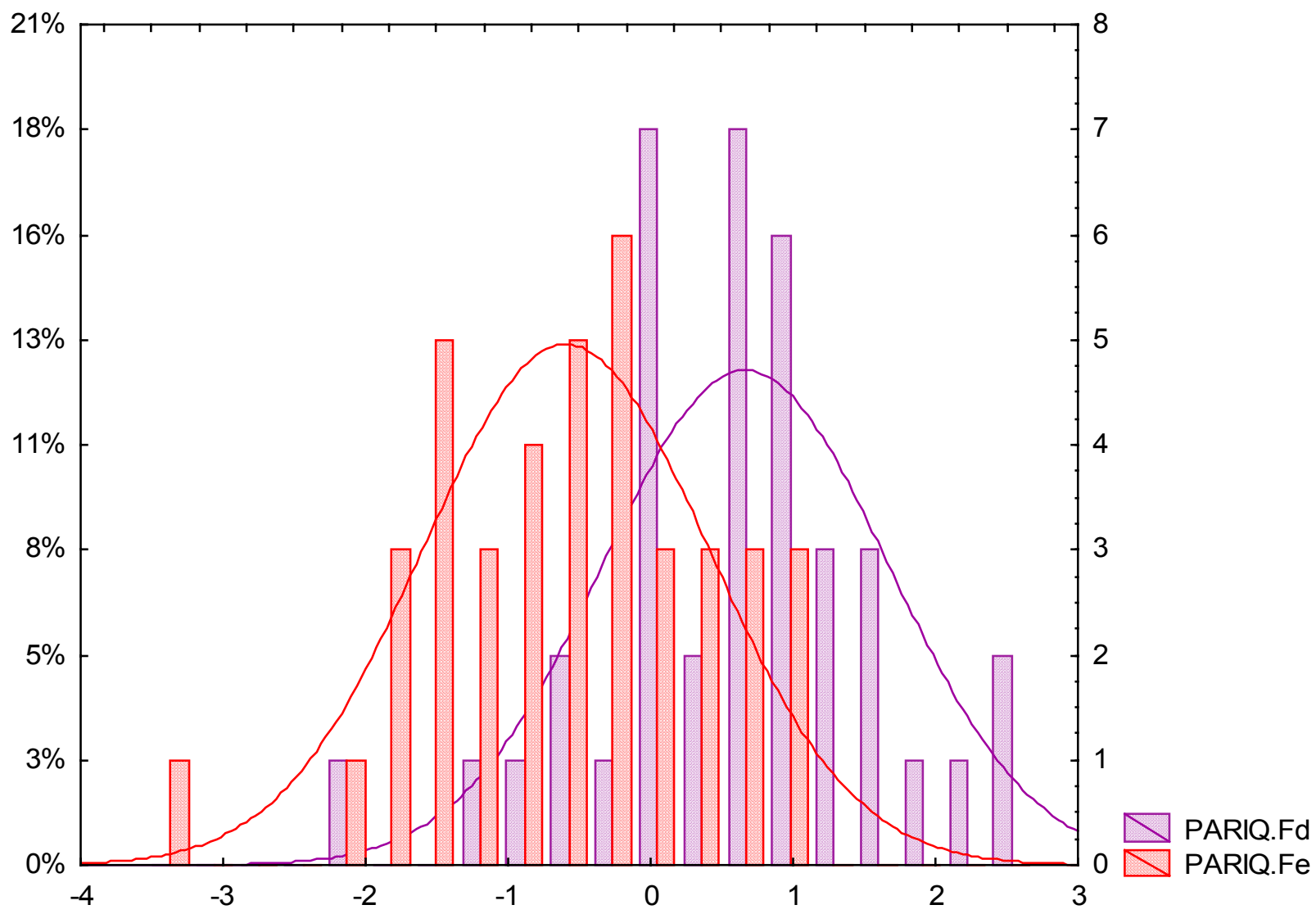

\section{Diagrama de grades - extremo negativo}

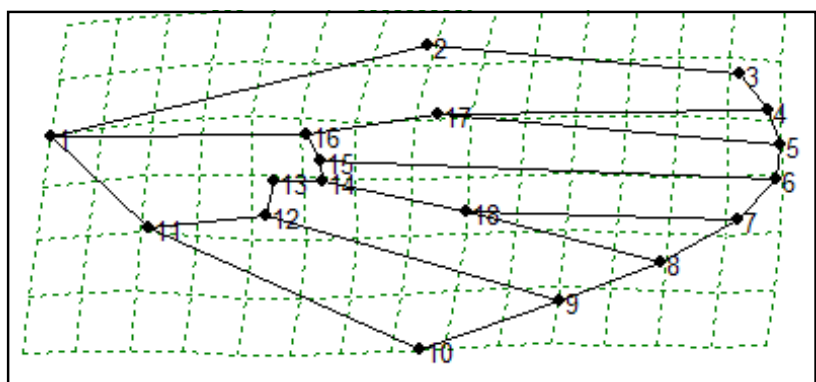

Diagrama de grades - extremo positivo

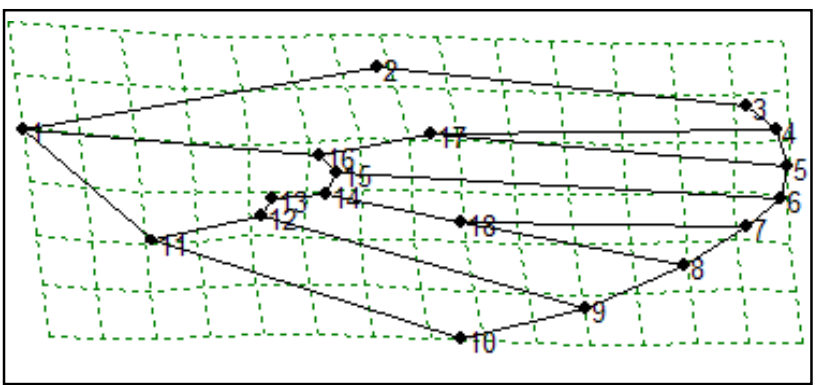

Figura A.9- Assimetria bilateral na população de fêmeas de PARIQ - Formato alar. Histograma de distribuição dos indivíduos ao longo da VC resultante da comparação entre asas direitas e esquerdas de fêmeas de PARIQ. Notar que há sobreposição entre as duas amostras. Abaixo, os respectivos diagramas de deformação. O diagrama à direita evidencia o extremo positivo, enquanto o da esquerda evidencia o extremo negativo. 
Machos PARIQ.

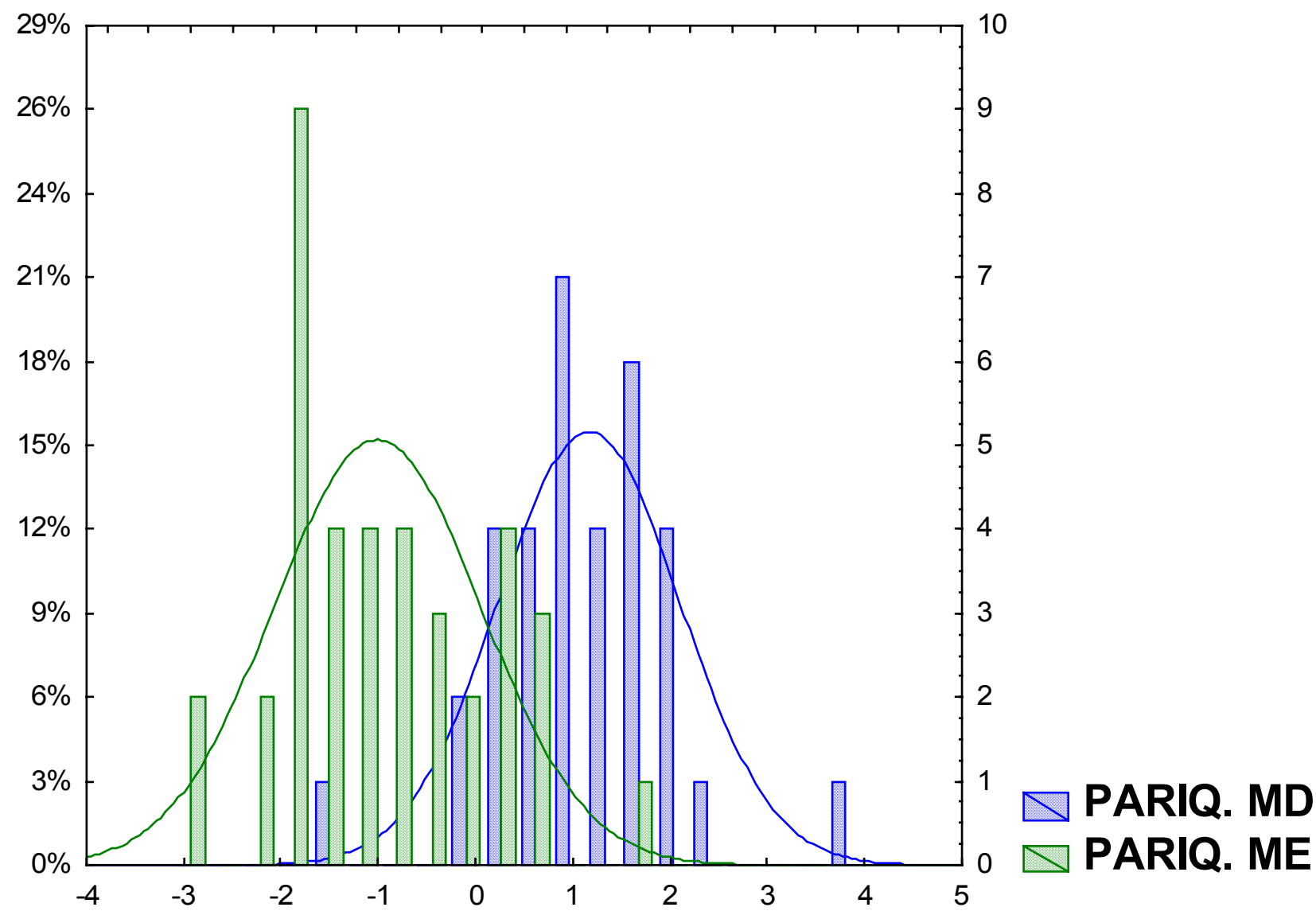

\section{Diagrama de grades - extremo negativo}

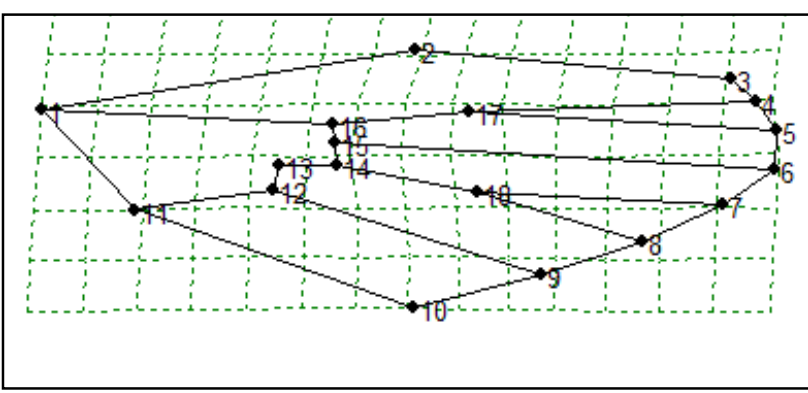

Diagrama de grades - extremo positivo

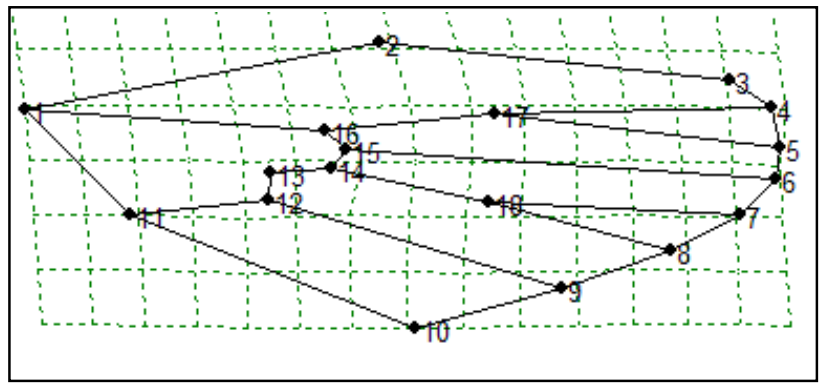

Figura A.10- Assimetria bilateral na população de machos de PARIQ - Formato alar. Histograma de distribuição dos indivíduos ao longo da VC resultante da comparação entre asas direitas e esquerdas de machos de PARIQ. Notar que há sobreposição entre as duas amostras. Abaixo, os respectivos diagramas de deformação. O diagrama à direita evidencia o extremo positivo, enquanto o da esquerda evidencia o extremo negativo. 
Fêmeas PET/ PARIQ.

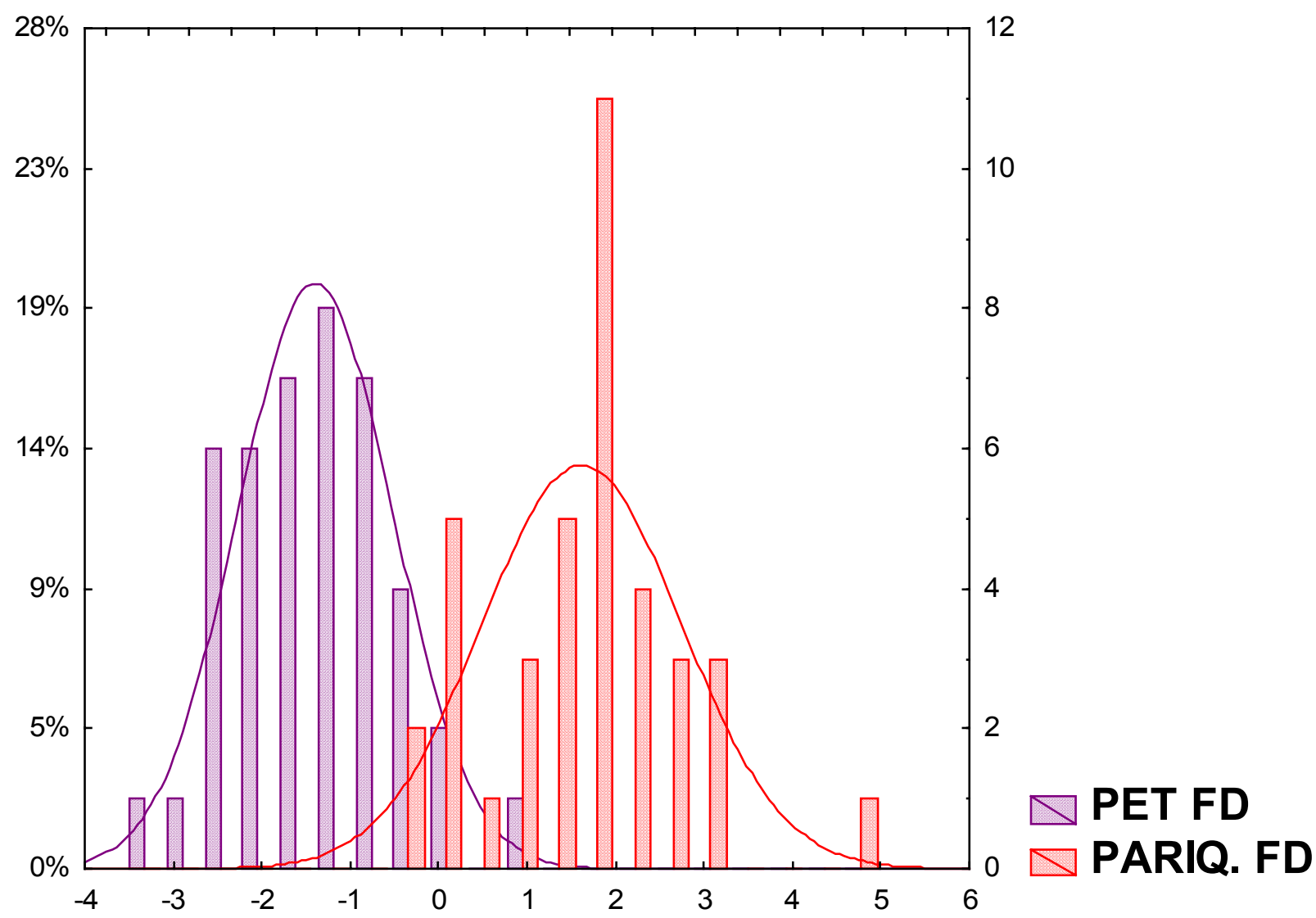

Diagrama de grades - extremo negativo

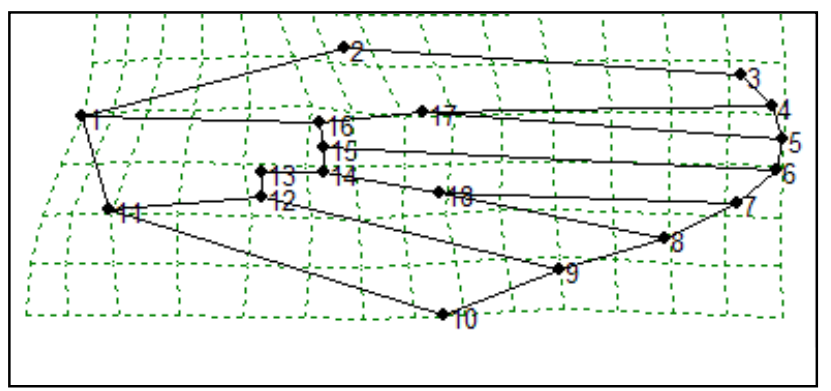

Diagrama de grades - extremo positivo

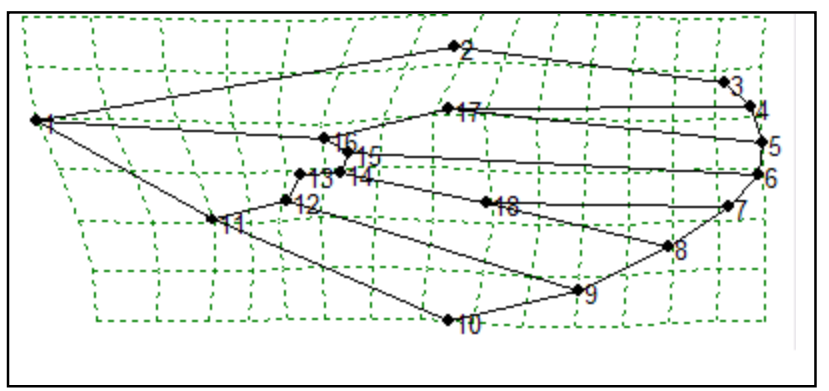

Figura A.11- Comparação Interpopulacional entre fêmeas PET/ PARIQ. Histograma de distribuição dos indivíduos ao longo da VC resultante da comparação entre fêmeas das duas populações. Notar que há uma pequena sobreposição entre elas, indicando que há diferenças entre as populações. Abaixo, os respectivos diagramas de deformação. O diagrama à esquerda evidencia o extremo negativo onde há maior distribuição de fêmeas do PET, enquanto o da direita evidencia o extremo positivo, onde há maior distribuição de fêmeas de PARIQ. 
Machos PARIQ.I PET

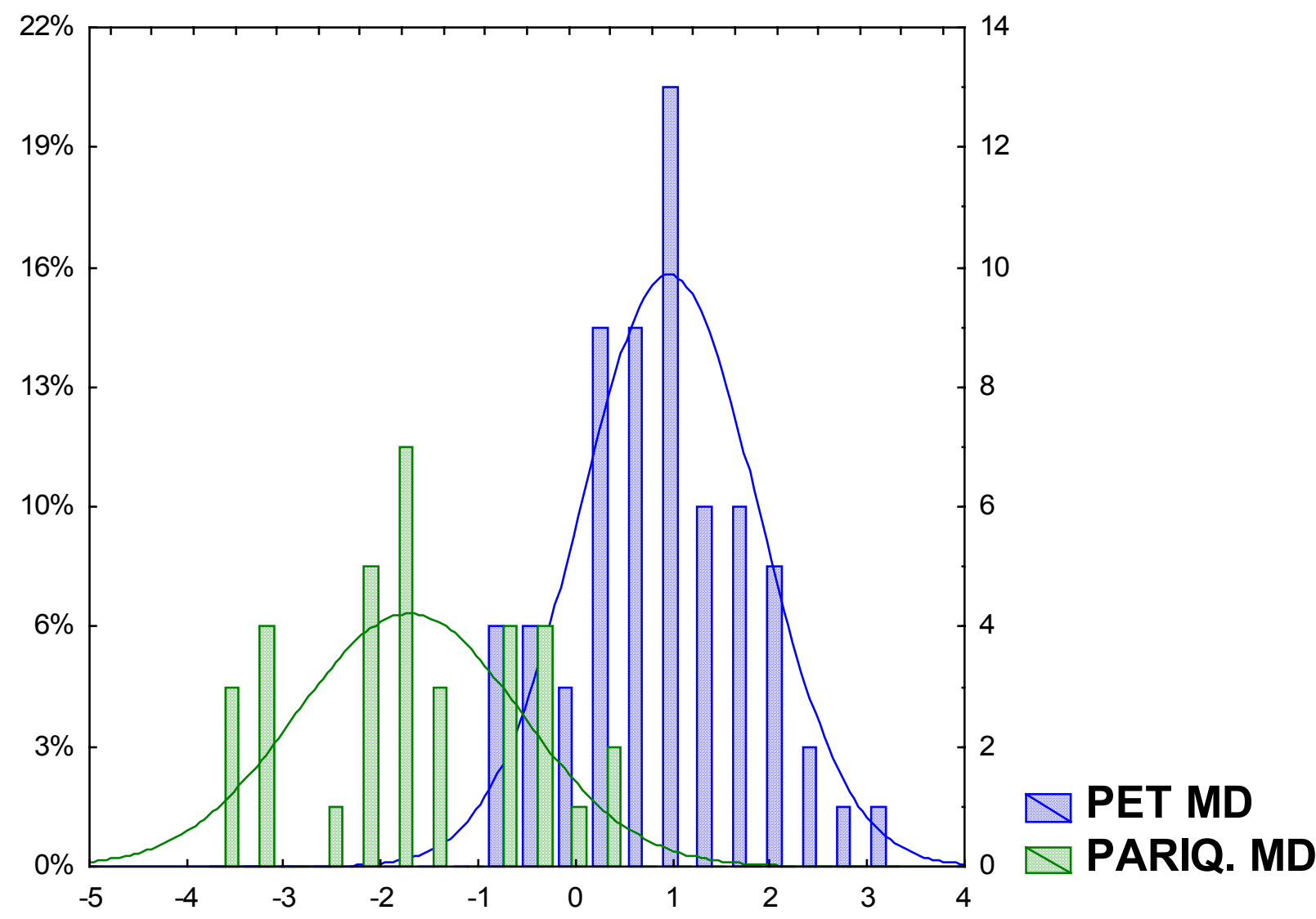

Diagrama de grades - extremo negativo

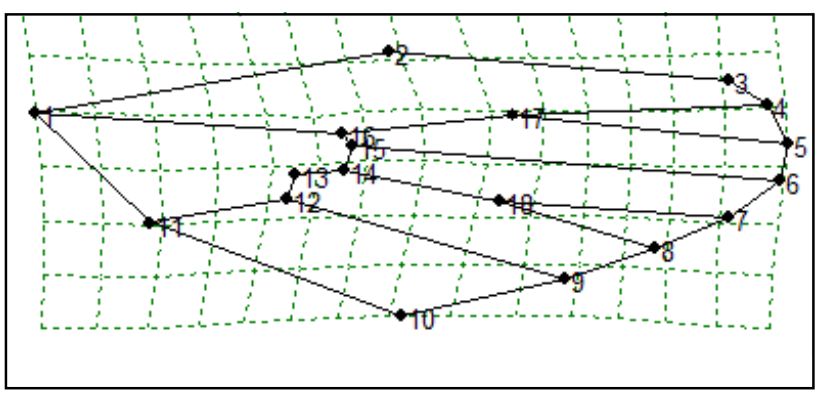

Diagrama de grades - extremo positivo

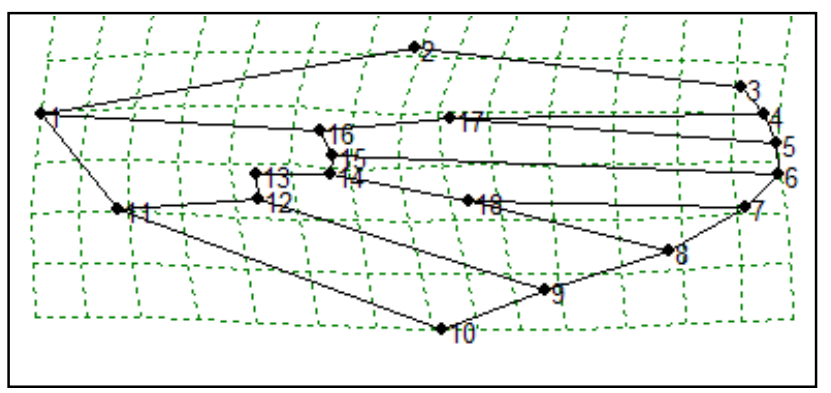

Figura A.12- Comparação Interpopulacional entre machos PET/ PARIQ. Histograma de distribuição dos indivíduos ao longo da VC resultante da comparação entre machos das duas populações. Notar que há uma pequena sobreposição entre elas, indicando que há diferenças entre as populações. Abaixo, os respectivos diagramas de deformação. $\mathrm{O}$ diagrama à direita evidencia o extremo positivo onde há maior distribuição de machos do PET, enquanto o da esquerda evidencia o extremo negativo, onde há maior distribuição de machos de PARIQ. 

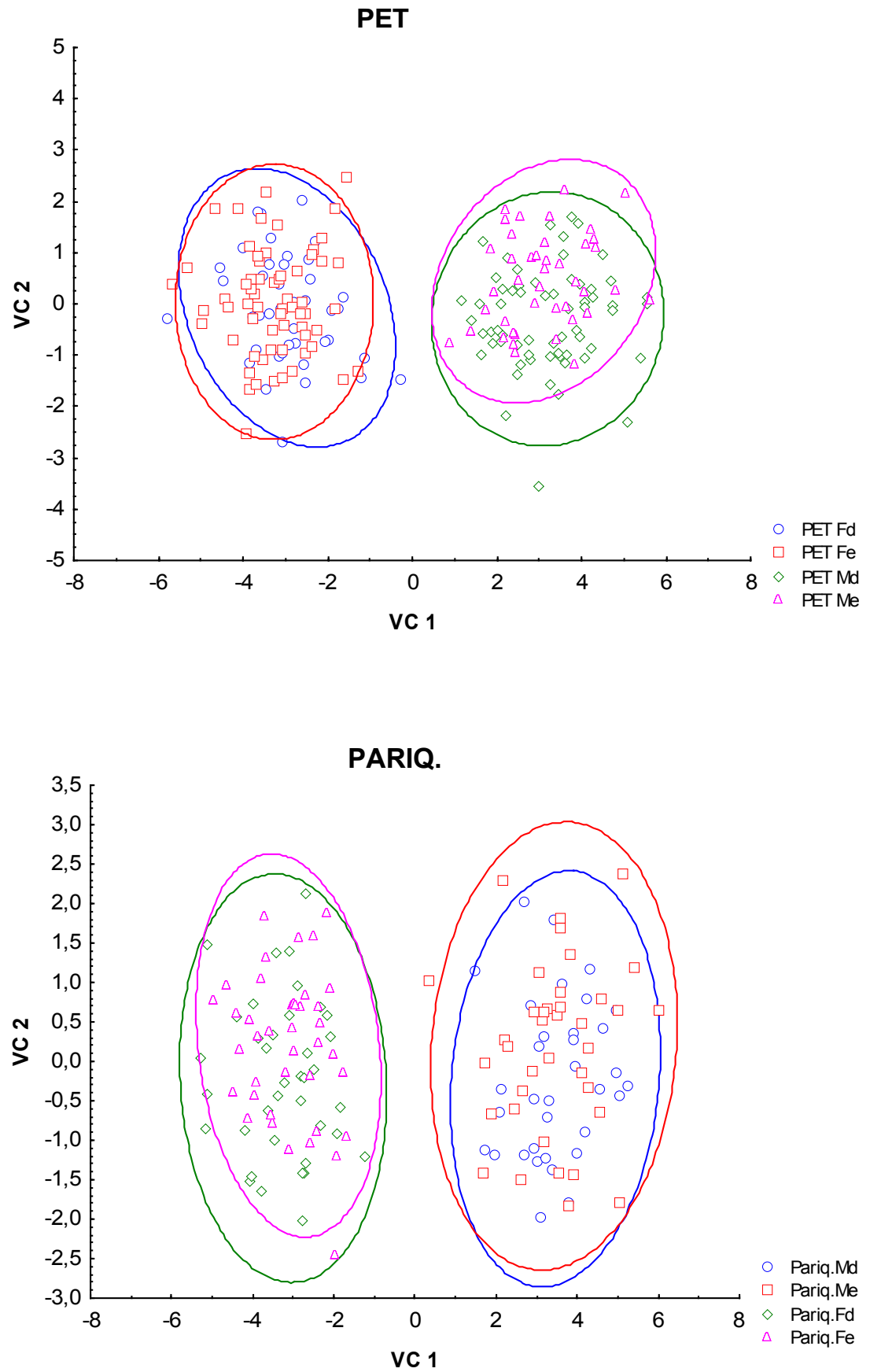

Figura A.13- Distribuição das VCs de fêmeas e machos do PET e PARIQ. Os gráficos bidimensionais são formados pelas VCs obtidas na comparação entre as amostras do PET (gráfico acima) e de PARIQ. (gráfico abaixo) indicadas nas legendas. Nos dois gráficos, as elipses indicam intervalo de $95 \%$ de confiança. F= Fêmea; $\mathrm{M}=$ Macho; $\mathrm{D}=$ Asa Direita; E= asa esquerda. Notar que há uma grande área de intersecção entre as amostras de fêmeas e entre as de machos, indicando baixa assimetria e nenhuma área de intersecção entre os sexos, indicando evidente dimorfismo sexual. 


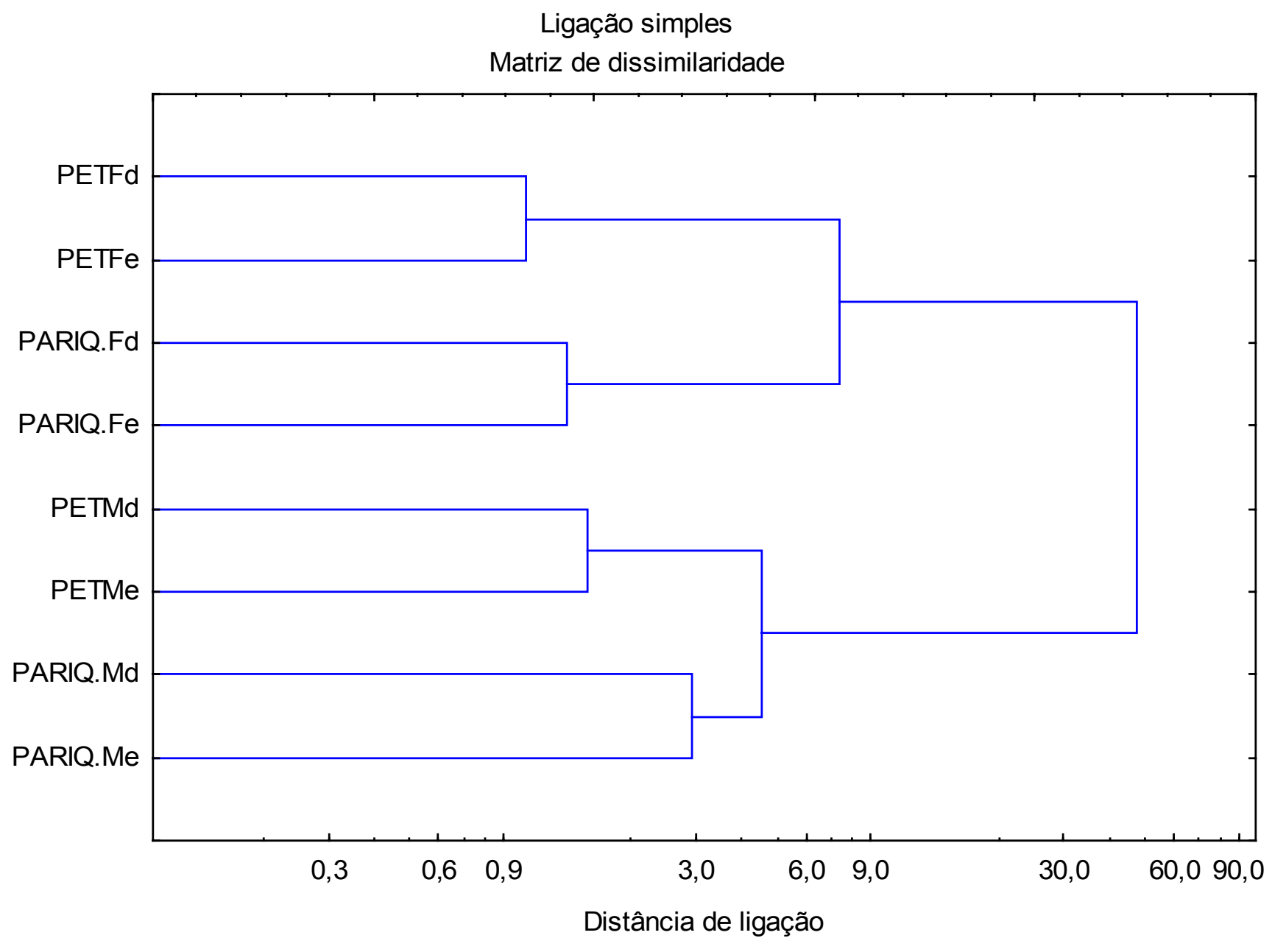

Figura A.14- Dendrograma com valores das distâncias de Mahalanobis. Feito a partir da matriz de dissimilaridade com valores de distância de Mahalanobis entre as amostras. 


\section{Tamanhos de Centróides}

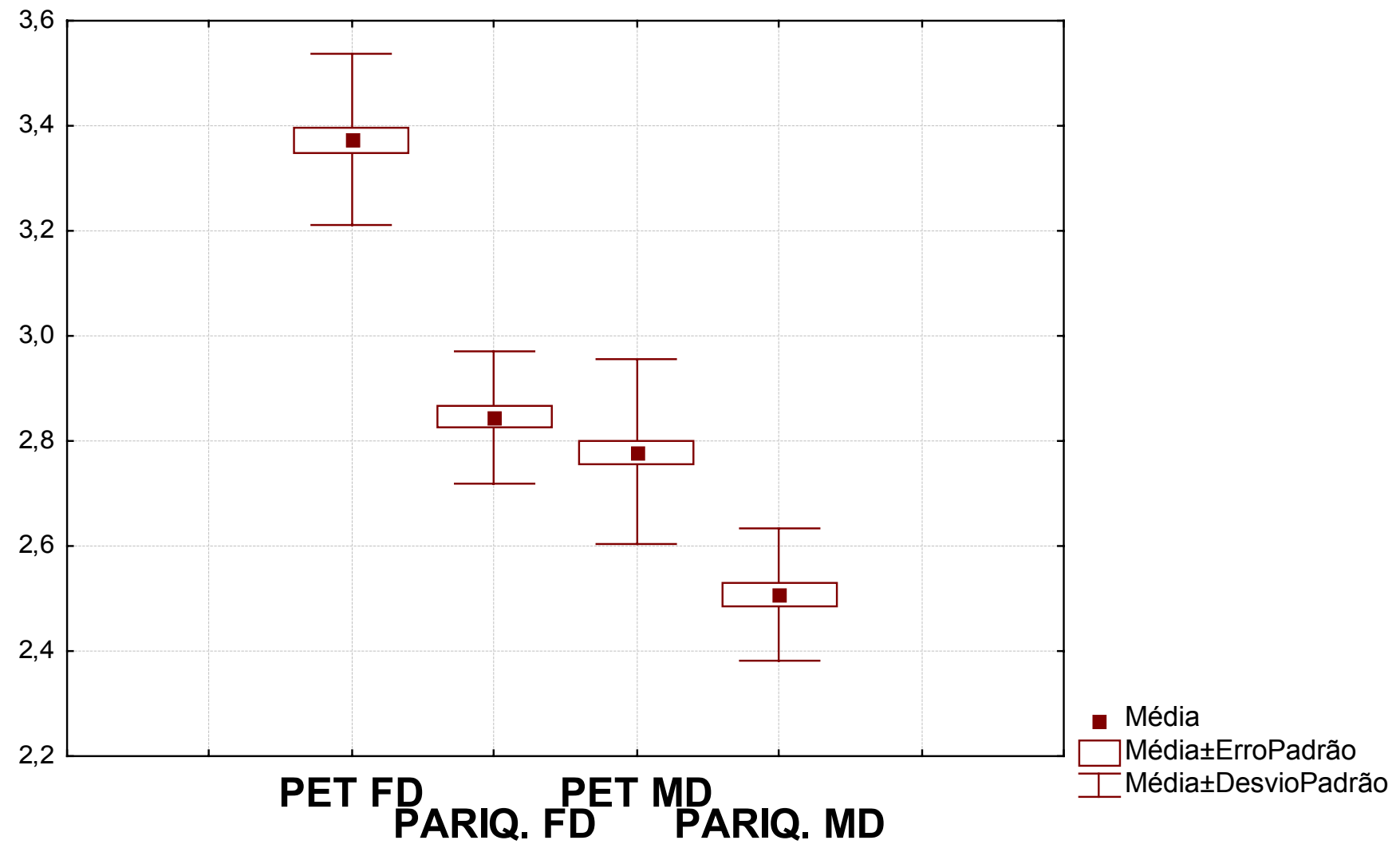

Figura A.15- Gráficos de centróides - Diferenças Interpopulacionais e dimorfismo sexual. Tamanhos de centróides de asas direitas de fêmeas e machos das duas populações. Nesse gráfico é possível notar diferenças entre as populações e o dimorfismo sexual dentro de cada população. Tamanhos em mm. 
Tamanhos de Centróides - Assimetria bilateral:

Fêmeas

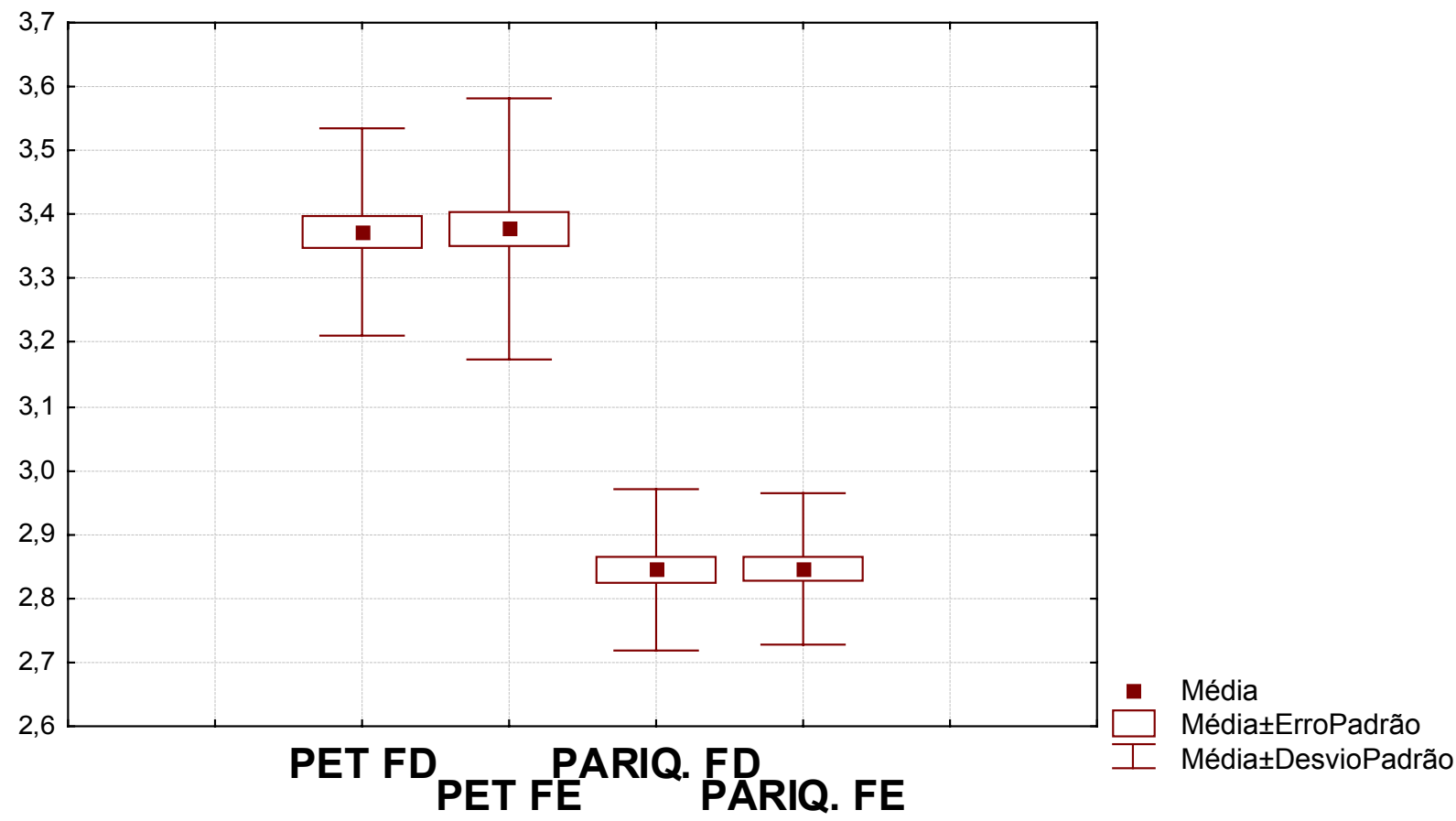

Tamanhos de Centróides - Assimetria bilateral:

Machos

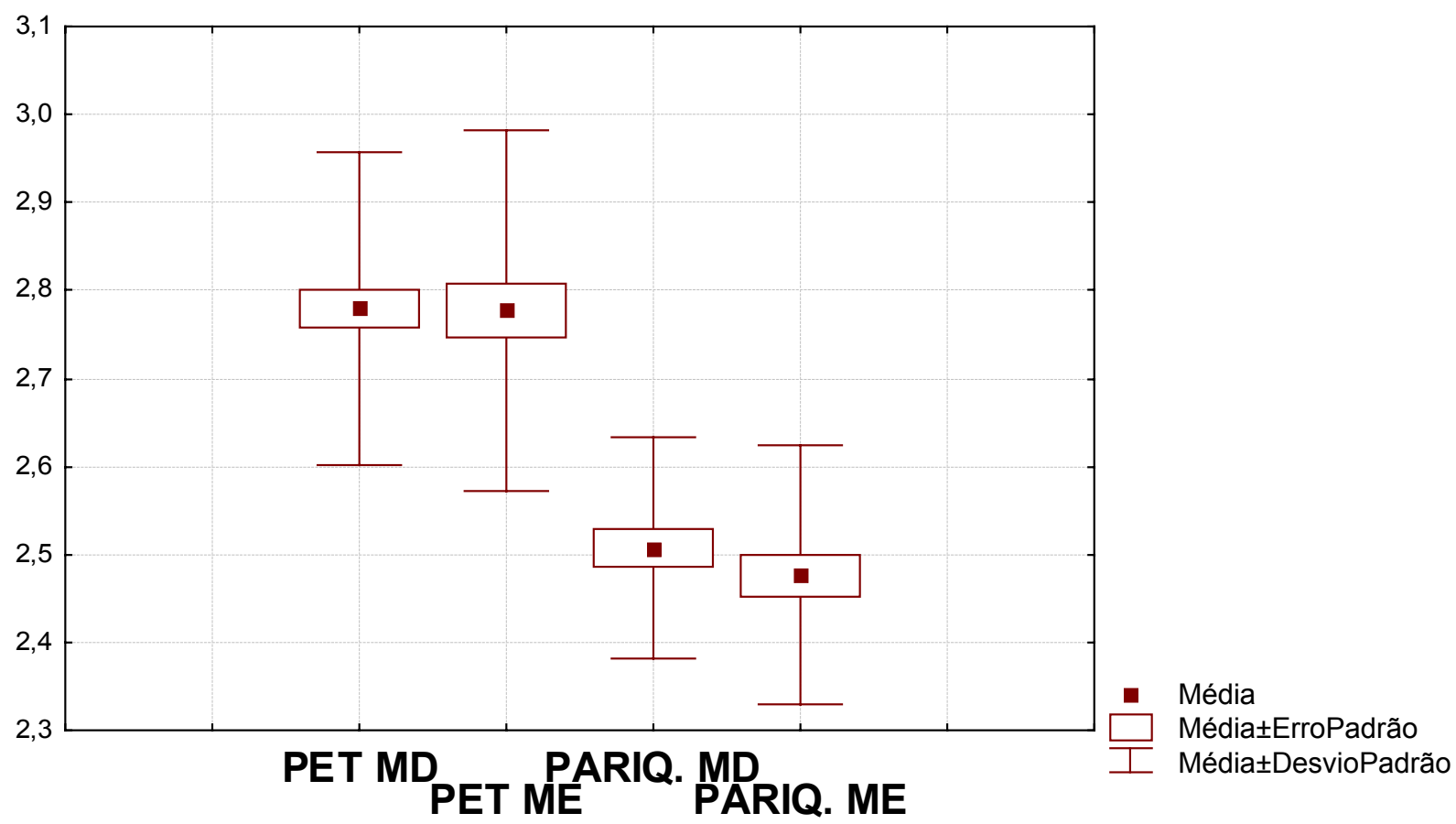

Figura A.16- Gráficos de centróides - Assimetria bilateral. Acima, representadas as asas de fêmeas. Abaixo, as asas de machos. Tamanhos em mm. 


\section{Gel}

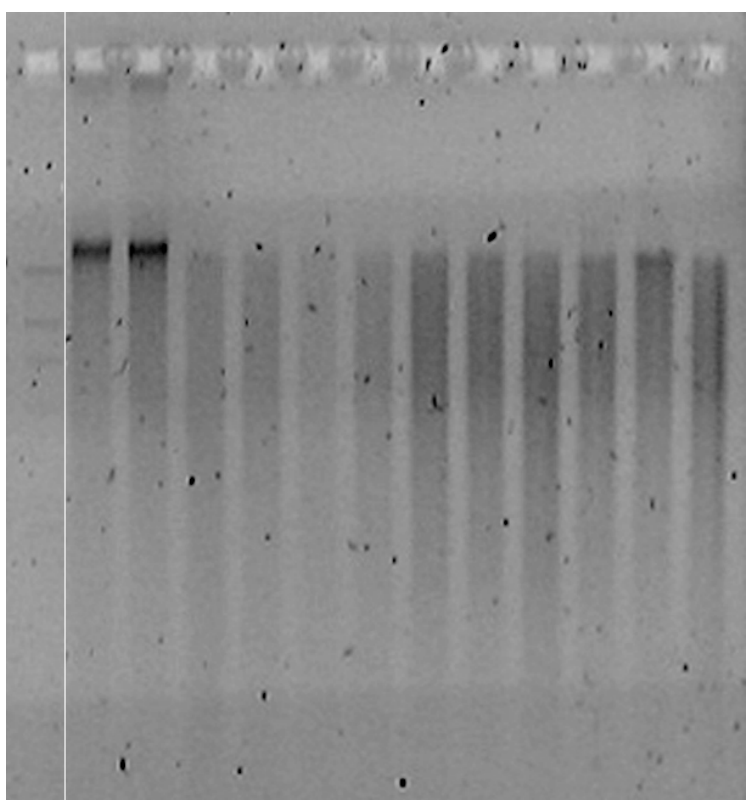

\section{Membrana}

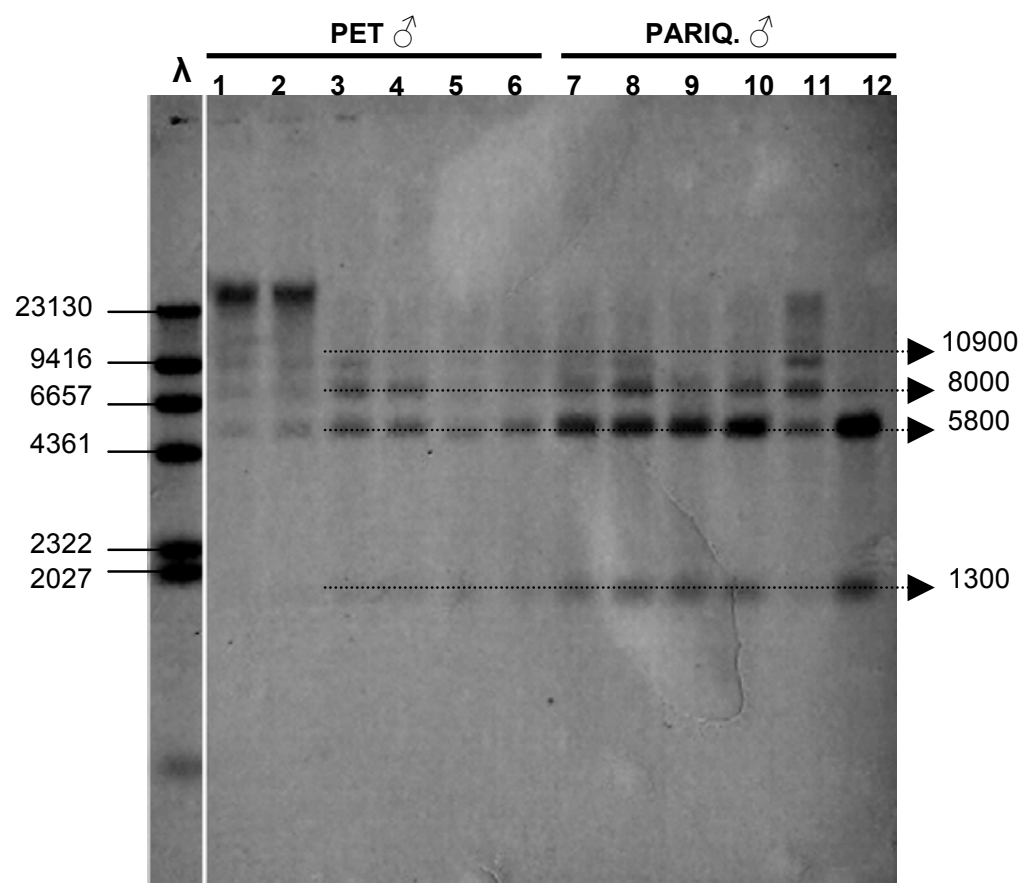

Figura A.17- Southern blotting PET/ PARIQ - DNAr clivado com EcoRI. À esquerda, gel de agarose a 0,8\% com amostras individuais de DNA genômico de machos das populações do PET e PARIQ. clivado com EcoRI. À direita, o respectivo Southern blot, com lavagem pós hibridação de alta estringência (SSC 0,1X e SDS 0,1\% a $65^{\circ} \mathrm{C}$ por 20 min), mostrando sinais de hibridação da sonda $D m 238$ com DNA de machos de $C x$. quinquefasciatus do PET (Raias 1 - 6) e de PARIQ. (Raias 7 -12). Nas raias 1 e 2 o DNA genômico não foi totalmente clivado. Nas outras amostras que tiveram clivagem total, são visíveis três bandas de tamanhos aproximados de 8000 pb, 5800 pb e 1300 pb (setas à direita) e uma banda de aproximadamente 10900 pb (seta à direita), é variavelmente notada em algumas amostras. Raia $\lambda=$ marcador de peso molecular $\lambda$ HindIII Biotinilado, cujos tamanhos de bandas em pb estão indicados ao lado esquerdo. 


\section{Gel}

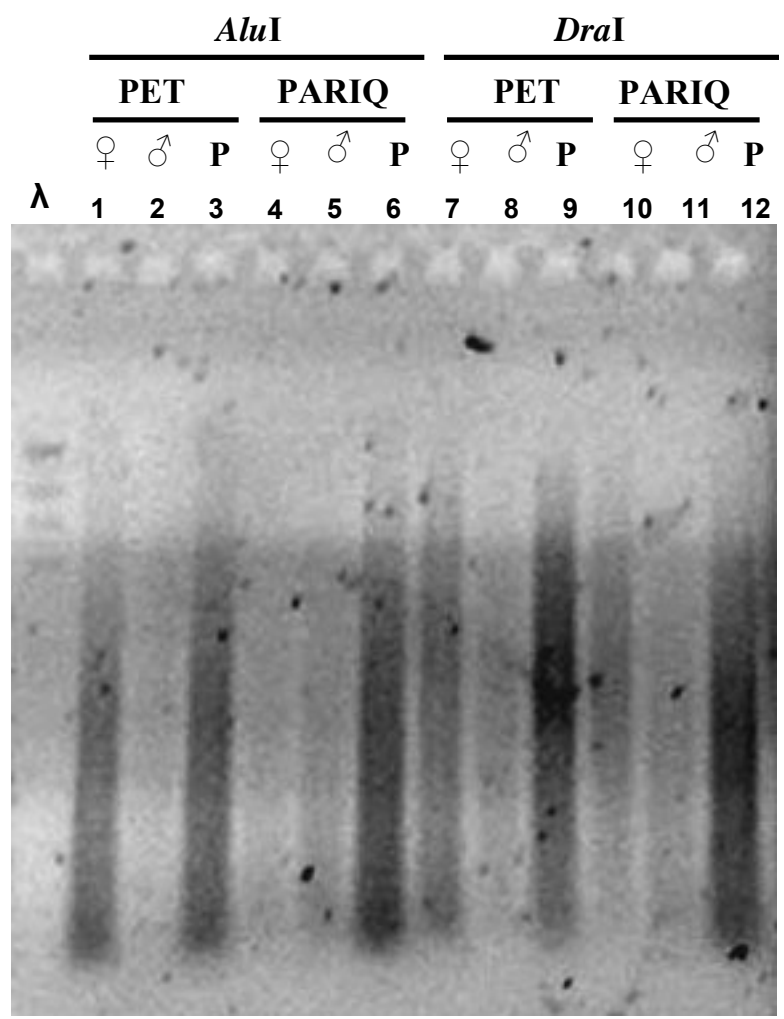

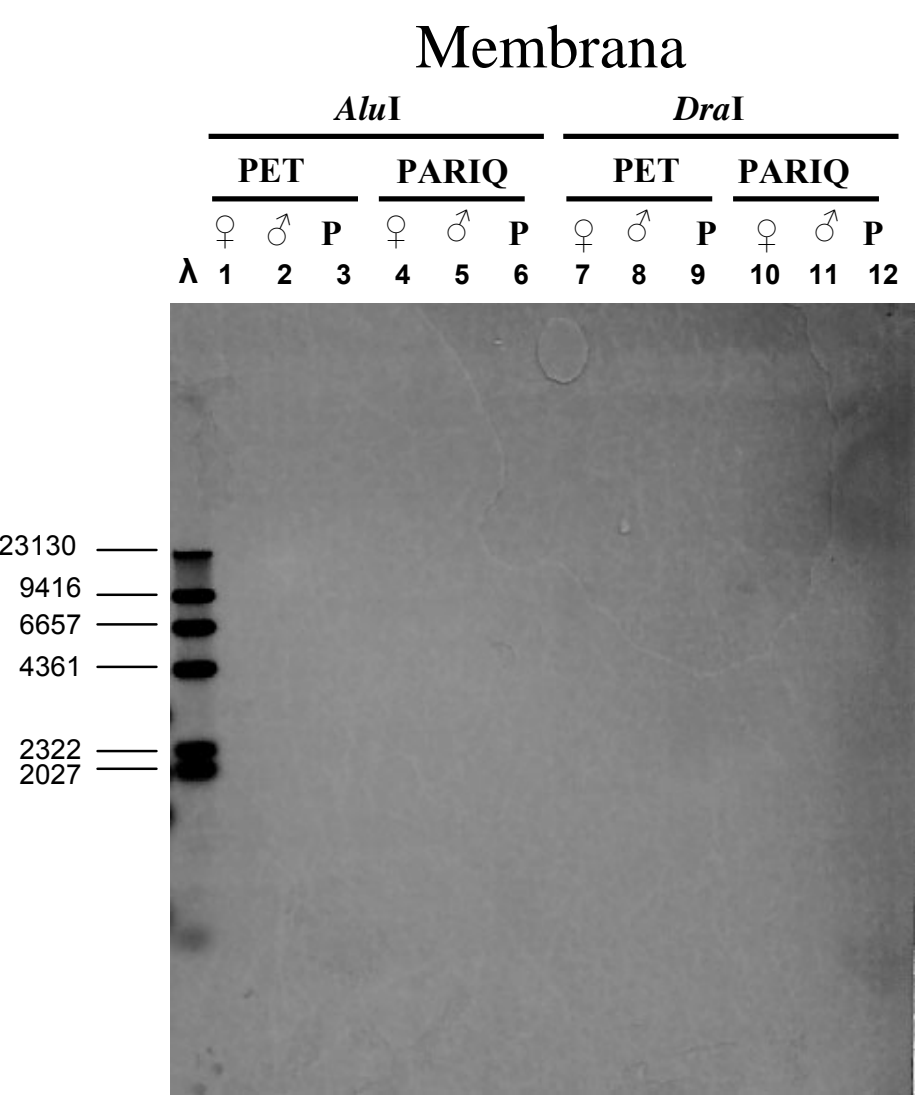

Figura A.18- Southern blotting PET/ PARIQ - DNAr clivado com AluI e DraI. À esquerda, gel de agarose a 0,8\% com amostras individuais e em pools de DNA genômico de fêmeas e machos das populações do PET e PARIQ. clivado com AluI e DraI. À direita, o respectivo Southern blot, com lavagem pós-hibridação de alta estringência (SSC 0,1X e SDS $0,1 \%$ a $65{ }^{\circ} \mathrm{C}$ por 20 min), mostrando sinais de hibridação da sonda $D m 238$ com DNA de $C x$. quinquefasciatus do PET e de PARIQ. Raia $\lambda=$ marcador de peso molecular $\lambda$ HindIII Biotinilado, cujos tamanhos de bandas em pb estão indicados ao lado esquerdo da membrana. Raias 1 e 2: DNA individual de fêmea e macho do PET (respectivamente) clivado com AluI. Raia 3: pool de DNA de fêmeas e machos do PET clivado com AluI. Raias 4 e 5: DNA individual de fêmea e macho de PARIQ. (respectivamente) clivados com AluI. Raia 6: pool de DNA de fêmeas e machos de PARIQ. clivado com AluI. O mesmo que foi feito para a enzima AluI nas raias $1-6$ foi feito para a enzima $D r a I$ nas raias 7 - 12. Sigla $\mathrm{P}=$ pool de indivíduos. 


\section{Gel}

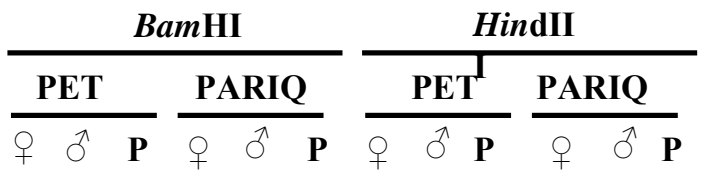

\section{$\lambda$}

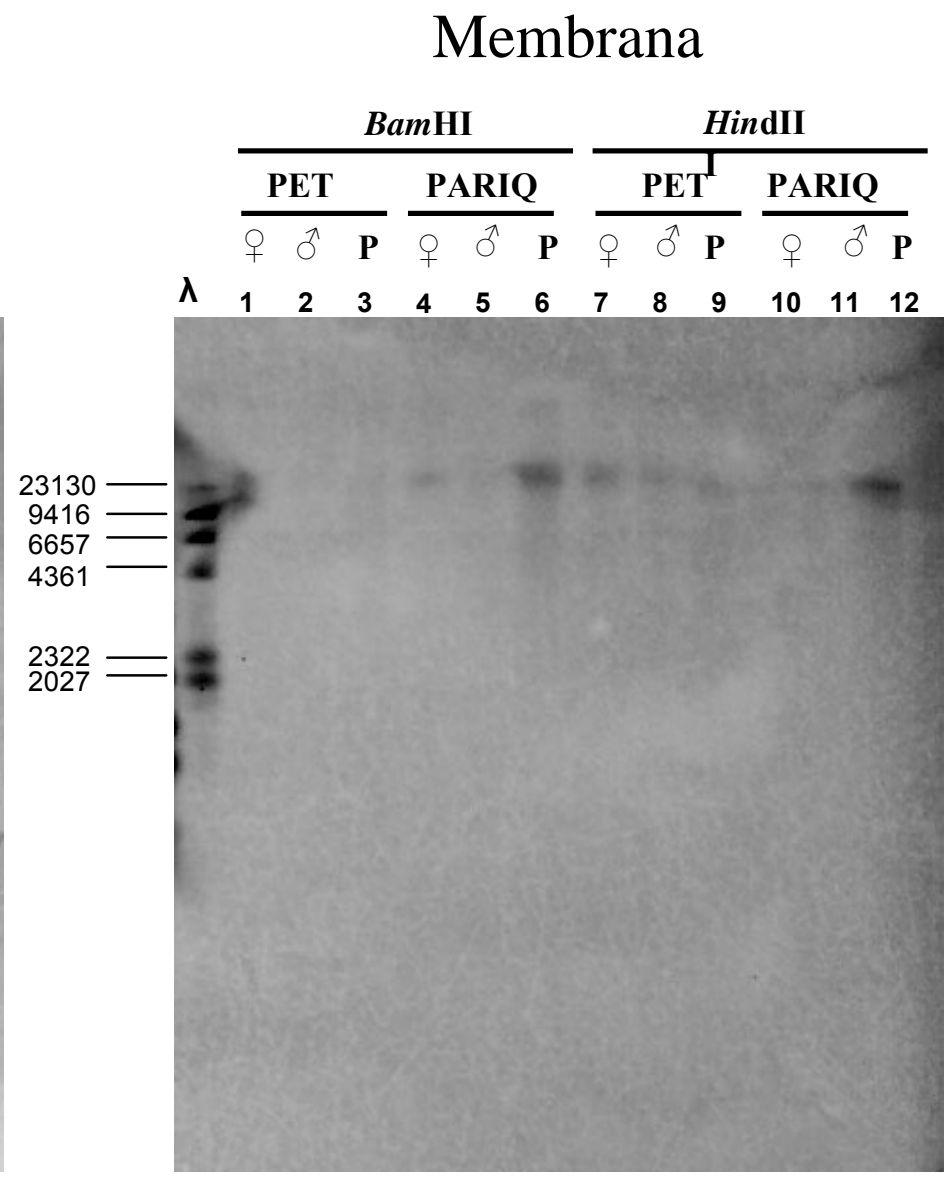

Membrana

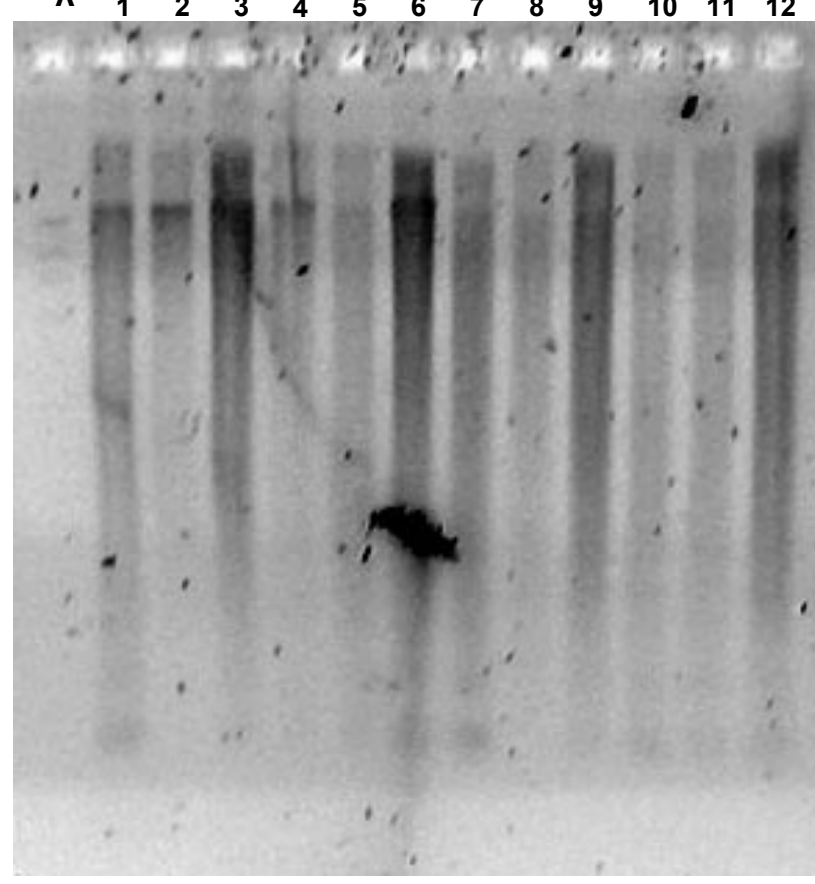

Figura A.19- Southern blotting PET/ PARIQ - DNAr clivado com BamHI e HindIII. À esquerda, gel de agarose a $0,8 \%$ com amostras individuais e em pools de DNA genômico de fêmeas e machos das populações do PET e PARIQ. clivado com BamHI e HindIII. À direita, o respectivo Southern blot, com lavagem pós hibridação de alta estringência (SSC 0,1X e SDS $0,1 \%$ a 65 oC por 20 min), mostrando sinais de hibridação da sonda Dm238 com DNA de $C x$. quinquefasciatus do PET e de PARIQ. Raia $\lambda=$ marcador de peso molecular $\lambda$ HindIII Biotinilado, cujos tamanhos de bandas em pb estão indicados ao lado esquerdo da membrana. Raias 1 e 2: DNA individual de fêmea e macho do PET (respectivamente) clivado com BamHI. Raia 3: pool de DNA de fêmeas e machos do PET clivado com BamHI. Raias 4 e 5: DNA individual de fêmea e macho de PARIQ. (respectivamente) clivados com BamHI. Raia 6: pool de DNA de fêmeas e machos de PARIQ. clivado com BamHI. O mesmo que foi feito para a enzima BamHI nas raias 1 - 6 foi feito para a enzima HindIII nas raias 7 - 12. 

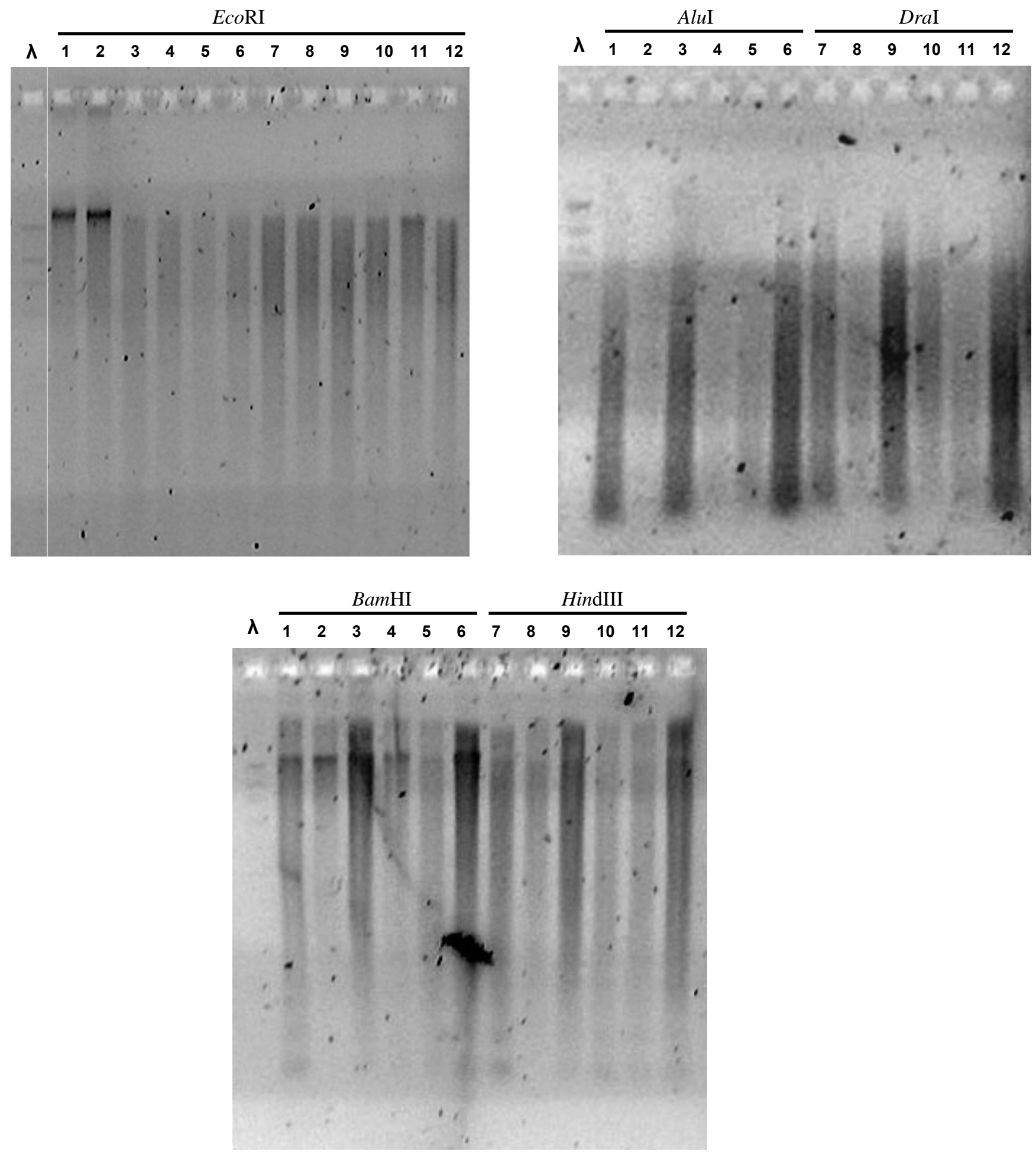

Figura A.20- Foto dos géis com DNAr clivado com as diferentes enzimas de restrição. Comparação dos géis com DNAr clivado com os cinco tipos de enzimas utilizadas nos experimentos de Southern blotting, evidenciando a presença geral de fragmentos menores nas preparações com AluI e DraI. 

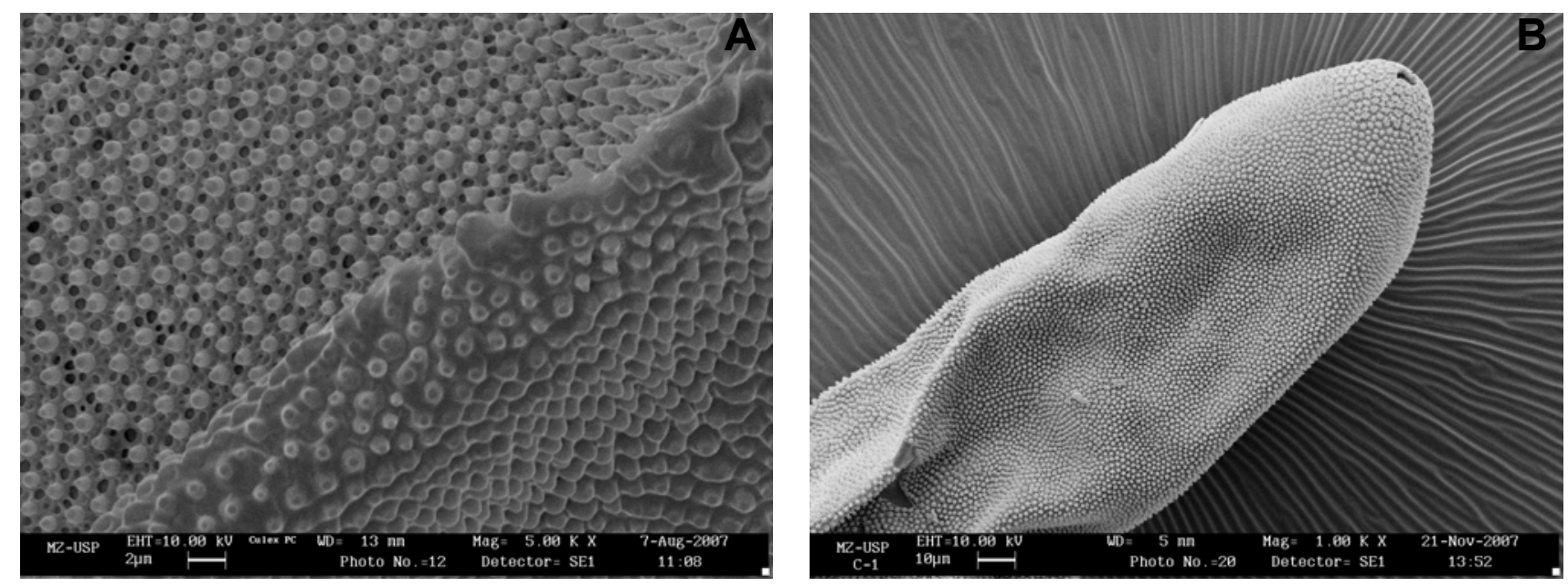

Figura A.21- Imagens de micrografia eletrônica. Ovo de $C x$. quinquefasciatus do PET. A. Camada mesh-work do exocórion com os tubérculos que foram medidos quanto à sua a altura e densidade (aumento de 5000X). B. Vista da metade apical anterior do ovo (aumento de 1000X).
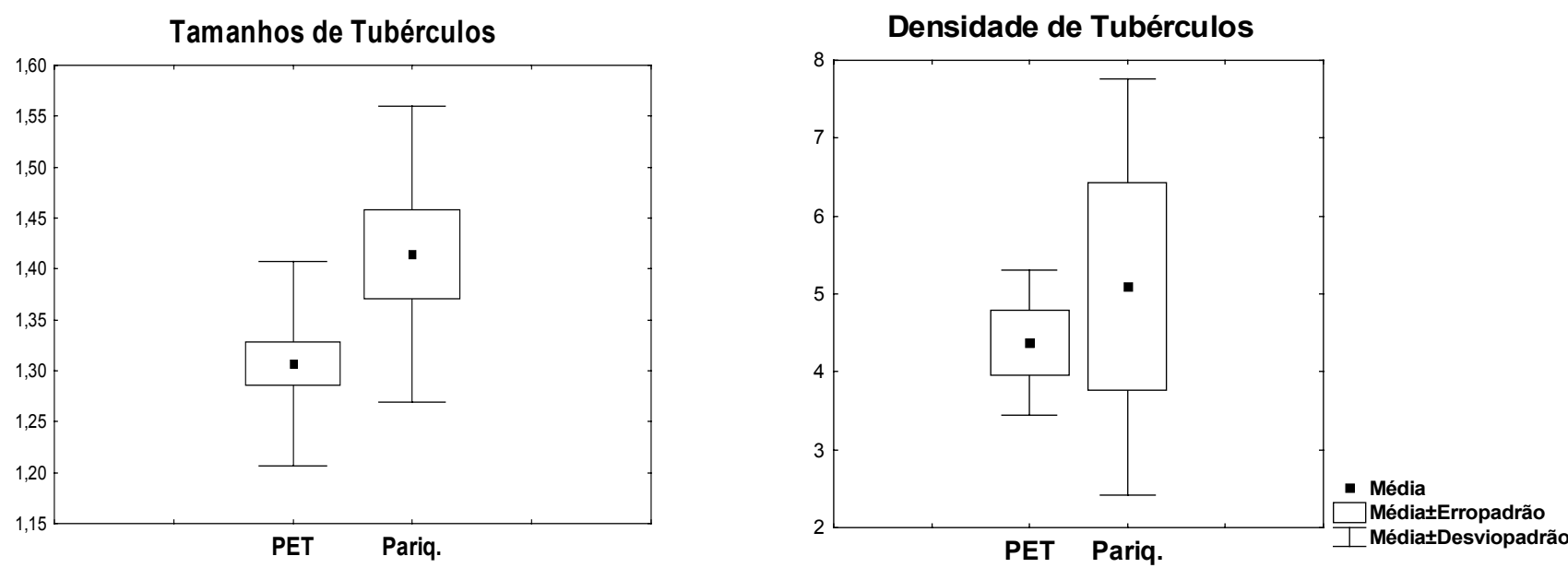

Figura A.22- Gráficos das medidas de tamanhos de tubérculos. No gráfico de tamanhos de tubérculos (medidas em $\mu \mathrm{m}$ ), à esquerda, há diferença estatisticamente significativa entre as populações. À direita, densidade de tubérculos por $\mu^{2}$. Em ambos os gráficos estão indicados as médias, erros e desvios-padrão. 
ANEXO B - Tabelas 
Tabela B.1- Coletas. Siglas (controle de coletas interno do laboratório) e dados de coleta das amostras populacionais de $C x$. quinquefasciatus.

\begin{tabular}{|c|c|c|c|c|c|}
\hline Amostra & Espécie & $\begin{array}{l}\text { Data } \\
\text { coleta }\end{array}$ & Procedência & $\begin{array}{l}\mathrm{N}^{\circ} \text { aproximado de } \\
\text { indivíduos utilizados }\end{array}$ & $\begin{array}{l}\text { Tipo de análise } \\
\text { realizada }\end{array}$ \\
\hline A1T1 & $\begin{array}{c}\text { Culex } \\
\text { quinquefasciatus }\end{array}$ & $27 / 6 / 2005$ & PET & $65 q$ e $65 \hat{\jmath}$ & Morfometria \\
\hline A14T1 & $\begin{array}{c}\text { Culex } \\
\text { quinquefasciatus }\end{array}$ & $17 / 4 / 2007$ & PET & 10 e $16{ }^{\widehat{\prime}}$ & DNA ribossômico \\
\hline A14T6 & $\begin{array}{c}\text { Culex } \\
\text { quinquefasciatus }\end{array}$ & $17 / 4 / 2007$ & PET & 19 (9 ovos) & Micrografia de ovos \\
\hline $\mathrm{A} 22 \mathrm{~T} 2$ & $\begin{array}{c}\text { Culex } \\
\text { quinquefasciatus }\end{array}$ & $27 / 4 / 2007$ & PARIQ & $6 \overbrace{}^{\lambda}$ & DNA ribossômico \\
\hline A33T1 & $\begin{array}{c}\text { Culex } \\
\text { quinquefasciatus }\end{array}$ & $18 / 12 / 2007$ & PARIQ & $32 \sigma^{\lambda}$ & Morfometria \\
\hline A33T3 & $\begin{array}{c}\text { Culex } \\
\text { quinquefasciatus }\end{array}$ & $18 / 12 / 2007$ & PARIQ & $1 q(5$ ovos $)$ & Micrografia de ovos \\
\hline A33T4 & $\begin{array}{c}\text { Culex } \\
\text { quinquefasciatus }\end{array}$ & $18 / 12 / 2007$ & PARIQ & $1+(3$ ovos $)$ & Micrografia de ovos \\
\hline A36T1 & $\begin{array}{c}\text { Culex } \\
\text { quinquefasciatus }\end{array}$ & $\mathrm{fev} / 08$ & PARIQ & $13+$ e $3 \hat{\jmath}$ & Morfometria \\
\hline A40T3 & $\begin{array}{c}\text { Culex } \\
\text { quinquefasciatus }\end{array}$ & $1 / 4 / 2008$ & PARIQ & $30 q$ & Morfometria \\
\hline
\end{tabular}


Tabela B.2- Altura de tubérculos. Valores das medidas de altura dos tubérculos do PET e de PARIQ.

\begin{tabular}{c|c|c|c}
\hline & \multicolumn{3}{|c}{ Tamanhos em $\mathbf{~ m}$} \\
\hline $\mathbf{T u b e ́ r c u l o ~}$ & $\mathbf{P E T}$ & PET & PARIQ \\
\hline $\mathbf{1}$ & 1,08 & 1,37 & 1,42 \\
\hline $\mathbf{3}$ & 1,21 & 1,23 & 1,51 \\
\hline $\mathbf{4}$ & 1,25 & 1,34 & 1,39 \\
\hline $\mathbf{5}$ & 1,22 & 1,42 & 1,3 \\
\hline $\mathbf{6}$ & 1,18 & 1,47 & 1,17 \\
\hline $\mathbf{7}$ & 1,31 & 1,39 & 1,53 \\
\hline $\mathbf{8}$ & 1,36 & 1,33 & 1,71 \\
\hline $\mathbf{9}$ & 1,24 & 1,46 & 1,39 \\
\hline $\mathbf{1 0}$ & 1,25 & 1,28 & 1,3 \\
\hline $\mathbf{1 1}$ & 1,14 & 1,37 & 1,33 \\
\hline $\mathbf{1 2}$ & 1,36 & 1,38 & 1,41 \\
\hline $\mathbf{M e ́ d i a}$ & & 1,31 & 1,36 \\
\hline
\end{tabular}

Tabela B.3- Densidade de tubérculos. Valores das medidas de densidade de tubérculos do PET e PARIQ.

\begin{tabular}{|c|c|c|c|}
\hline & $\begin{array}{l}\text { Área do quadrado } \\
\left(\mu^{2}\right)\end{array}$ & $\begin{array}{l}\text { Quantidade de } \\
\text { tubérculos }\end{array}$ & $\begin{array}{c}\text { Densidade } \\
\text { (tubérculos } / \mu \mathrm{m}^{2} \text { ) }\end{array}$ \\
\hline \multirow[t]{5}{*}{ PET } & 64 & 30 & 3,75 \\
\hline & 100 & 47 & 4,70 \\
\hline & 100 & 31 & 3,10 \\
\hline & 100 & 54 & 5,40 \\
\hline & 100 & 49 & 4,90 \\
\hline Média & & & 4,37 \\
\hline \multirow[t]{4}{*}{ PARIQ } & 144 & 34 & 2,83 \\
\hline & 100 & 29 & 2,90 \\
\hline & 100 & 82 & 8,20 \\
\hline & 81 & 58 & 6,44 \\
\hline Média & & & 5,09 \\
\hline
\end{tabular}


Tabela B.4- Matriz de reclassificação para fêmeas PET/ PARIQ. Classificações preditas na reclassificação para fêmeas das duas populações.

\begin{tabular}{c|c|c|c}
\hline & & \multicolumn{2}{|c}{$\mathrm{N}^{\mathrm{o}}$ de indivíduos classificados } \\
\hline & Porcentagem correta & PET FD & PARIQ. FD \\
\hline PET FD & $95 \%$ & 41 & 2 \\
\hline PARIQ. FD & $82 \%$ & 7 & 31 \\
\hline Total & $89 \%$ & 48 & 33 \\
\hline
\end{tabular}

Tabela B.5- Matriz de reclassificação para machos PET/ PARIQ. Classificações preditas na reclassificação para machos das duas populações.

\begin{tabular}{c|c|c|c}
\hline & & \multicolumn{2}{|c}{$\mathbf{N}^{\mathbf{0}}$ de indivíduos classificados } \\
\hline & Porcentagem correta & PET MD & PARIQ. MD \\
\hline PET MD & $95 \%$ & 60 & 2 \\
\hline PET MD & $76 \%$ & 8 & 31 \\
\hline Total & $88 \%$ & 68 & 33 \\
\hline
\end{tabular}

Tabela B.6- Distâncias de Mahalanobis. Valores das distâncias de Mahalanobis entre todos o espécimes analisados.

\begin{tabular}{c|c|c|c|c|c|c|c|c}
\hline & PET FD & PET FE & PET MD & PET ME & PARIQ.MD & PARIQ. ME & PARIQ. FD & PARIQ. FE \\
\hline PET FD & 0 & 1,03 & 50,06 & 47,27 & 63,18 & 63,12 & 7,46 & 7,41 \\
\hline PET FE & 1,03 & 0 & 53,03 & 49,36 & 67,85 & 67,03 & 8,18 & 8,15 \\
\hline PET MD & 50,06 & 53,03 & 0 & 1,52 & 4,54 & 6,79 & 61,78 & 60,32 \\
\hline PET ME & 47,27 & 49,36 & 1,52 & 0 & 6,31 & 6,87 & 60,67 & 58,95 \\
\hline PARIQ. MD & 63,18 & 67,85 & 4,54 & 6,31 & 0 & 2,95 & 72,31 & 71,76 \\
\hline PARIQ. ME & 63,12 & 67,03 & 6,79 & 6,87 & 2,95 & 0 & 74,30 & 73,17 \\
\hline PARIQ. FD & 7,46 & 8,18 & 61,78 & 60,67 & 72,31 & 74,30 & 0 & 1,33 \\
\hline PARIQ. FE & 7,41 & 8,15 & 60,32 & 58,95 & 71,76 & 73,17 & 1,33 & 0 \\
\hline
\end{tabular}


Tabela B.7- Tamanhos de centróides PET. Valores em milímetros para cada indivíduo das amostras populacionais do PET.

\begin{tabular}{|c|c|c|c|}
\hline \multicolumn{4}{|c|}{ PET } \\
\hline FD & FE & MD & ME \\
\hline 3,4749 & 3,2418 & 2,6054 & 2,6601 \\
\hline 3,4926 & 3,4646 & 2,7034 & 2,9838 \\
\hline 3,4484 & 3,7192 & 2,9381 & 2,9267 \\
\hline 3,3051 & 3,5234 & 2,9489 & 2,7789 \\
\hline 3,4013 & 3,4917 & 2,891 & 2,1405 \\
\hline 3,4322 & 3,4005 & 2,7562 & 2,087 \\
\hline 3,5088 & 3,6721 & 2,1554 & 2,9658 \\
\hline 3,3702 & 3,5463 & 2,0851 & 3,1218 \\
\hline 3,2995 & 3,3833 & 2,9611 & 2,8415 \\
\hline 3,4471 & 3,4338 & 3,1054 & 2,7669 \\
\hline 3,2736 & 3,5259 & 2,8631 & 2,8005 \\
\hline 3,4347 & 3,4016 & 2,7768 & 2,8591 \\
\hline 3,3505 & 3,3027 & 2,8005 & 2,8501 \\
\hline 3,1648 & 3,455 & 2,8575 & 2,9183 \\
\hline 3,2248 & 3,2672 & 2,915 & 2,7827 \\
\hline 3,1865 & 3,4424 & 2,7543 & 2,7517 \\
\hline 3,2213 & 3,3494 & 2,7341 & 2,8019 \\
\hline 3,5401 & 3,2076 & 2,8383 & 2,8552 \\
\hline 3,4419 & 3,2008 & 2,9032 & 2,7947 \\
\hline 3,5001 & 3,0395 & 2,6977 & 2,916 \\
\hline 3,3855 & 3,2174 & 2,8216 & 2,8049 \\
\hline 3,5835 & 3,5216 & 2,9461 & 2,7971 \\
\hline 3,3668 & 3,4945 & 2,7767 & 2,9826 \\
\hline 3,3667 & 3,5234 & 2,9242 & 2,785 \\
\hline 3,5438 & 3,3591 & 2,9682 & 2,4853 \\
\hline 3,165 & 3,5803 & 2,7413 & 2,9369 \\
\hline 3,8582 & 3,4093 & 2,789 & 2,9917 \\
\hline 3,0219 & 3,3474 & 2,8303 & 2,7698 \\
\hline 3,4642 & 3,5397 & 2,2545 & 2,7928 \\
\hline 3,1295 & 3,1753 & 2,733 & 2,8245 \\
\hline 3,1545 & 3,8423 & 2,7891 & 2,2705 \\
\hline 3,18 & 3,0126 & 2,6446 & 2,7385 \\
\hline 3,3282 & 3,989 & 2,814 & 2,7915 \\
\hline 3,1771 & 3,4773 & 2,819 & 2,8119 \\
\hline 3,2489 & 3,2042 & 2,8178 & 2,8513 \\
\hline 3,4597 & 3,0474 & 2,8469 & 2,7106 \\
\hline 3,516 & 3,4524 & 2,8325 & 2,7313 \\
\hline 3,5227 & 3,1459 & 2,7174 & 2,975 \\
\hline 3,6071 & 3,2426 & 2,9689 & 2,6402 \\
\hline 3,2418 & 3,156 & 2,6071 & 2,7871 \\
\hline 3,2771 & 3,0432 & 2,7882 & 2,7864 \\
\hline 3,3822 & 2,7934 & 2,7641 & 2,7715 \\
\hline
\end{tabular}

\begin{tabular}{r|r|r|l}
\hline 3,5585 & 3,1671 & 2,9142 & \\
\hline & 3,2574 & 2,6651 & \\
\hline & 3,2909 & 2,8375 & \\
\hline & 3,4032 & 2,6665 & \\
\hline & 3,5423 & 2,8608 & \\
\hline & 3,275 & 2,7713 & \\
\hline & 3,3867 & 2,9188 & \\
\hline & 3,3135 & 2,6435 & \\
\hline & 3,3978 & 2,6344 & \\
\hline & 3,3721 & 2,6542 & \\
\hline & 3,5525 & 2,8922 & \\
\hline & 3,3114 & 2,9385 & \\
\hline & 3,4262 & 2,803 & \\
\hline & 3,2543 & 2,7463 & \\
\hline & 3,3784 & 2,8501 & \\
\hline & 3,197 & 2,7139 & \\
\hline & 3,4368 & 2,5972 & \\
\hline & 3,5482 & 3,0287 & \\
\hline & 3,3234 & 2,9404 & \\
\hline & 3,5972 & 2,7593 & \\
\hline & 3,7318 & 2,7895 & \\
\hline & & & \\
\hline
\end{tabular}


Tabela B.8- Tamanhos de centróides PARIQ. Valores em milímetros para cada indivíduo das amostras populacionais de PARIQ.

\begin{tabular}{|c|c|c|c|}
\hline \multicolumn{4}{|c|}{ PARIQ } \\
\hline FD & FE & MD & ME \\
\hline 2,816754 & 2,736644 & 2,779507 & 2,793192 \\
\hline 2,720521 & 2,725317 & 2,613587 & 2,598624 \\
\hline 2,828911 & 2,823932 & 2,693824 & 2,746285 \\
\hline 2,79972 & 2,811566 & 2,495163 & 2,495757 \\
\hline 3,010909 & 2,944066 & 2,515629 & 2,536826 \\
\hline 2,729679 & 3,031741 & 2,494409 & 2,480857 \\
\hline 2,72283 & 2,729314 & 2,625852 & 2,650238 \\
\hline 2,852986 & 2,817688 & 2,530446 & 2,524392 \\
\hline 2,688469 & 2,733458 & 2,437673 & 2,456369 \\
\hline 2,812976 & 2,82207 & 2,45447 & 2,446248 \\
\hline 2,491307 & 2,719853 & 2,340376 & 2,370604 \\
\hline 2,75721 & 2,816993 & 2,470539 & 2,503993 \\
\hline 2,829056 & 2,514614 & 2,410591 & 2,395382 \\
\hline 2,967171 & 2,769714 & 2,732686 & 2,75927 \\
\hline 2,95722 & 2,813864 & 2,589174 & 2,599041 \\
\hline 2,976617 & 2,997116 & 2,565549 & 2,567104 \\
\hline 3,007175 & 2,978389 & 2,471659 & 2,491541 \\
\hline 2,458942 & 2,98565 & 2,629178 & 2,602404 \\
\hline 2,79021 & 2,988945 & 2,600962 & 2,373622 \\
\hline 2,86702 & 2,498574 & 2,498585 & 2,469734 \\
\hline 2,862029 & 2,821438 & 2,453379 & 2,470196 \\
\hline 2,724786 & 2,858894 & 2,414221 & 2,302271 \\
\hline 2,78888 & 2,864285 & 2,608625 & 2,430797 \\
\hline 2,852567 & 2,877489 & 2,475393 & 2,600584 \\
\hline 2,904375 & 2,725627 & 2,546612 & 2,556017 \\
\hline 3,028556 & 2,797344 & 2,452298 & 2,285485 \\
\hline 3,006171 & 2,859261 & 2,587251 & 2,438691 \\
\hline 2,886607 & 2,946005 & 2,393316 & 2,393089 \\
\hline 2,842104 & 3,023722 & 2,538247 & 2,538931 \\
\hline 2,816592 & 2,961978 & 2,588171 & 2,567004 \\
\hline 2,960396 & 2,895428 & 2,311689 & 2,282116 \\
\hline 2,975175 & 2,829245 & 2,372583 & 2,627984 \\
\hline 2,870829 & 2,811036 & 2,391658 & 2,37383 \\
\hline 2,945959 & 2,958585 & 2,151492 & 2,363994 \\
\hline 2,856742 & 2,887128 & & 2,18185 \\
\hline 2,902812 & 2,935629 & & 2,288819 \\
\hline 2,900352 & 2,840796 & & 2,369385 \\
\hline \multirow[t]{3}{*}{2,910964} & 2,87968 & & 2,15722 \\
\hline & 2,914214 & & \\
\hline & 2,897055 & & \\
\hline
\end{tabular}


Tabela B.9- Aplicação de testes estatísticos para amostras do PET. Resultados da aplicação de teste T estatístico (fêmeas) e teste Mann-Whitney (machos), na comparação das médias de tamanhos de centróides entre asas direitas e esquerdas de fêmeas e machos do PET.

\begin{tabular}{c|c|c}
\hline Amostra populacional & PET - Fêmeas & PET - Machos \\
\hline Assimetria significativa? & Não & Não \\
\hline Valor de p & $=0,94$ & $=0,71$ \\
\hline
\end{tabular}

Tabela B.10- Aplicação de testes estatísticos para amostras de PARIQ. Resultados da aplicação de teste T estatístico na comparação das médias de tamanhos de centróides entre asas direitas e esquerdas de fêmeas e machos de PARIQ.

\begin{tabular}{c|c|c}
\hline Amostra populacional & PARIQ - Fêmeas & PARIQ - Machos \\
\hline Assimetria significativa? & Não & Não \\
\hline Valor de $\mathbf{p}$ & $=0,97$ & $=0,34$ \\
\hline
\end{tabular}

Tabela B.11- Aplicação de testes estatísticos para machos e fêmeas de PET e PARIQ. Resultados da aplicação de teste T estatístico na comparação das médias de tamanhos de centróides entre asas direitas de fêmeas e machos das duas populações.

\begin{tabular}{c|c|c}
\hline Amostra populacional & PET & PARIQ \\
\hline Dimorfismo sexual significativo? & Sim & Sim \\
\hline Valor de $\mathbf{p}$ & $<0,0001$ & $<0,0001$ \\
\hline
\end{tabular}

Tabela B.12- Aplicação de testes estatísticos para comparação de PET/ PARIQ. Resultados da aplicação de teste T estatístico na comparação das médias de tamanhos de centróides entre populações distintas. Amostragem apenas de asas direitas de fêmeas e machos das duas populações.

\begin{tabular}{c|c|c}
\hline Amostra populacional & $\begin{array}{c}\text { PET/ PARIQ - } \\
\text { Fêmeas }\end{array}$ & $\begin{array}{c}\text { PET/ PARIQ - } \\
\text { Machos }\end{array}$ \\
\hline Populações diferem significamente? & Sim & $\operatorname{Sim}$ \\
\hline Valor de $\mathbf{p}$ & $<0,0001$ & $<0,0001$ \\
\hline
\end{tabular}


ANEXO C - Trabalho Publicado 


\title{
NOVOS CARACTERES DIAGNÓSTICOS PARA MOSQUITOS DE INTERESSE MÉDICO: Culex quinquefasciatus E Culex corniger (DIPTERA; CULICIDAE).
}

\author{
Moratore, C.; Suesdek, L. \\ Instituto Butantan/Seção Parasitologia, Av Vital Brasil, 1500 - São Paulo, SP, Brasil, moratorec@usp.br; \\ linrocha@butantan.gov.br
}

Resumo- Culex quinquefasciatus é uma espécie de mosquito de grande interesse médico, sua distribuição geográfica é pantropical e possui hábitos sinantrópicos podendo desenvolver-se em ambientes urbanos sob ação de inseticidas e poluentes. Outra espécie de mosquito de potencial interesse médico é Culex corniger que também pode ser encontrada em ambientes urbanos sob condições semelhantes às de $C x$. quinquefasciatus. Devido ao fato de essas duas espécies poderem ocupar o mesmo nicho, pode tornar-se difícil diagnosticá-las taxonomicamente em situações em que os indivíduos estão mal-preservados. Para tal identificação foi usada morfometria geométrica alar e análise multivariada discriminante comparativa entre fêmeas das duas espécies o que gerou uma variável canônica acusativa de dissimilaridades espécieespecíficas. As principais diferenças puderam ser observadas na veia alar $R_{2+3}$. Esse tipo de análise mostrou ser uma ferramenta útil para diferenciar essas espécies quando ocorrem em simpatria, com base apenas em caracteres alares.

Palavras-chave: Culicídeo, morfometria, geométrica, asas, taxonomia. Área do Conhecimento: Ciências Biológicas.

\section{Introdução}

Culex quinquefasciatus Say, é uma espécie de mosquito de grande interesse médico por ser a principal vetora de filariose bancroftiana no Brasil e por transmitir arbovírus entre animais e humanos, como o vírus do Nilo Ocidental (WNV), o agente etiológico de uma severa encefalite. Sua distribuição geográfica é pantropical, seus adultos e larvas têm hábitos sinantrópicos e podem desenvolver-se em ambientes urbanos onde freqüentemente apresentam tolerância a poluentes e inseticidas (NATAL; UENO, 2004).

Outra espécie de mosquito encontrada em ambientes urbanos nas Américas é Culex corniger Theobald. É uma espécie de potencial interesse médico que ocorre desde o México até o Uruguai, sendo capaz de reproduzir-se em criadouros artificiais e coleções hídricas ricas em matéria orgânica, como córregos poluídos conectados a esgotos (FORATTINI et al, 1998), (FORATTINI, 2002).

Essas duas espécies muitas vezes são encontradas em simpatria e em muitos casos as larvas vivem sintopicamente nos mesmos criadouros, ocupando nichos ecológicos semelhantes (AVENDANO-LOPEZ; CALDERONARGUEDAS, 2006). Embora esses táxons sejam facilmente distinguidos quando em bom estado de conservação, a ocorrência conjunta dessas espécies requer cautela na identificação taxonômica, sobretudo quando os espécimes estão danificados ou conservados em etanol.

Este trabalho propôs-se a definir caracteres alares que permitam diferenciar as espécies $C x$. quinquefasciatus e Cx. corniger, os quais poderiam ser usados como marcadores taxonômicos para culicídeos mal-preservados. Para tal, asas foram descritas por morfometria geométrica e comparadas por análise multivariada discriminante.

\section{Metodologia}

Exemplares de $C x$. quinquefasciatus e $C x$. corniger foram coletados no município de Pariquera-Açu, no estado de São Paulo em Abril/2008. Foram coletadas larvas de um rio poluído do município, das quais emergiram os adultos usados na análise. Os adultos ficaram armazenados em etanol $70 \%$.

Asas de fêmeas de $C x$. corniger $(n=55)$ e de $C x$. quinquefasciatus $(n=56)$, após remoção das escamas, foram montadas com Entellan (Merck) entre lâmina-lamínula. Imagens dessas asas foram capturadas através de uma câmera digital acoplada a um microscópio estereoscópico Leica S6 (Fig.1- A).

Sobre essas imagens e com o auxílio do "software" TpsDig V.1.40 (QSC - Rohlf, J. http://www.life.bio.sunysb.edu/morph/) foram tomadas as coordenadas posicionais de cada um dos 18 pontos anatômicos (Fig.1- B) sobre um plano cartesiano, de acordo com a metodologia da morfometria geométrica (ROHLF, 2005). Sobre esses dados foram computados os tamanhos de centróide e as variáveis canônicas (VCs), com o auxílio dos programas de computador TpsUtil 1.29, TpsRelw 1.39 (QSC) e Statistica 7.0 (StatSoft). 

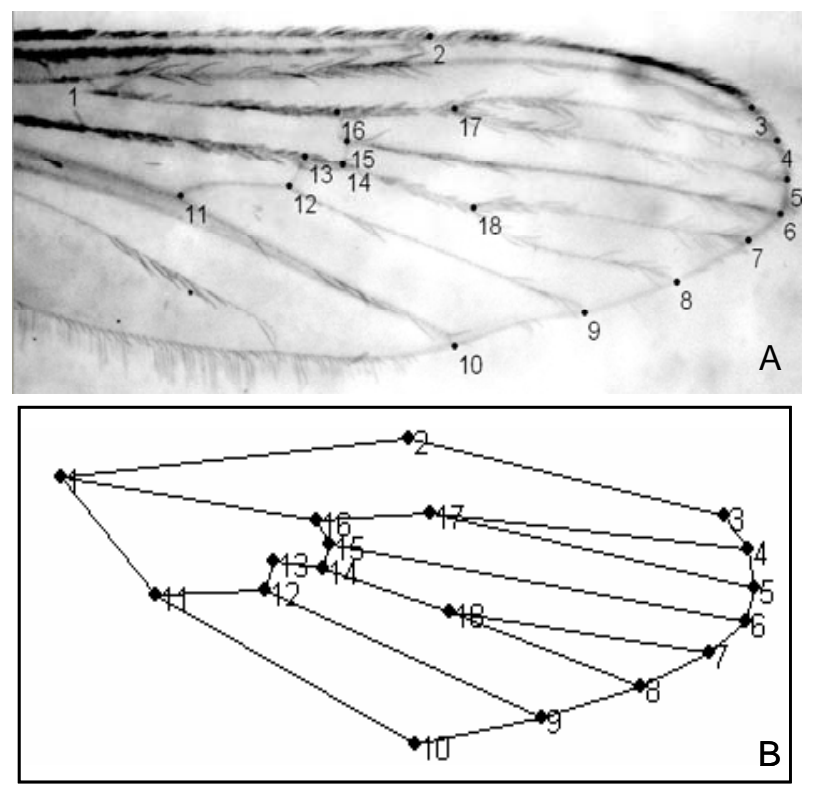

Figura 1. (A) Asa de $C x$. quinquefasciatus mostrando os pontos anatômicos. (B) Representação gráfica do consenso alar formado pelos 18 pontos anatômicos ligados por linhas para facilitar a visualização.
Duas análises comparativas foram feitas: variáveis canônicas e tamanhos de centróide. A análise de variáveis canônicas, que descreve apenas forma, foi empregada na comparação pareada entre as duas espécies e utilizada no estudo de deformações em diagramas de grades.

A outra análise, a de tamanhos de centróide, descreve apenas tamanho. O tamanho do centróide varia com o tamanho da asa e é uma forma de sumarizar o tamanho dessa estrutura em uma única variável.

\section{Resultados}

A análise discriminante multivariada gerou uma variável canônica na comparação entre as duas espécies (Fig.2), cujos valores variaram de -7,0 a $+7,5$. Amostras da espécie $C x$. quinquefasciatus distribuíram-se entre -7,0 e -3,0, com média de 5,0 e $C x$. corniger distribuíram-se entre $+2,0$ e $+7,5$, com média de $+5,0$. Não houve sobreposição das espécies ao longo do eixo da variável canônica, permitindo assim, a distinção inequívoca das espécies.

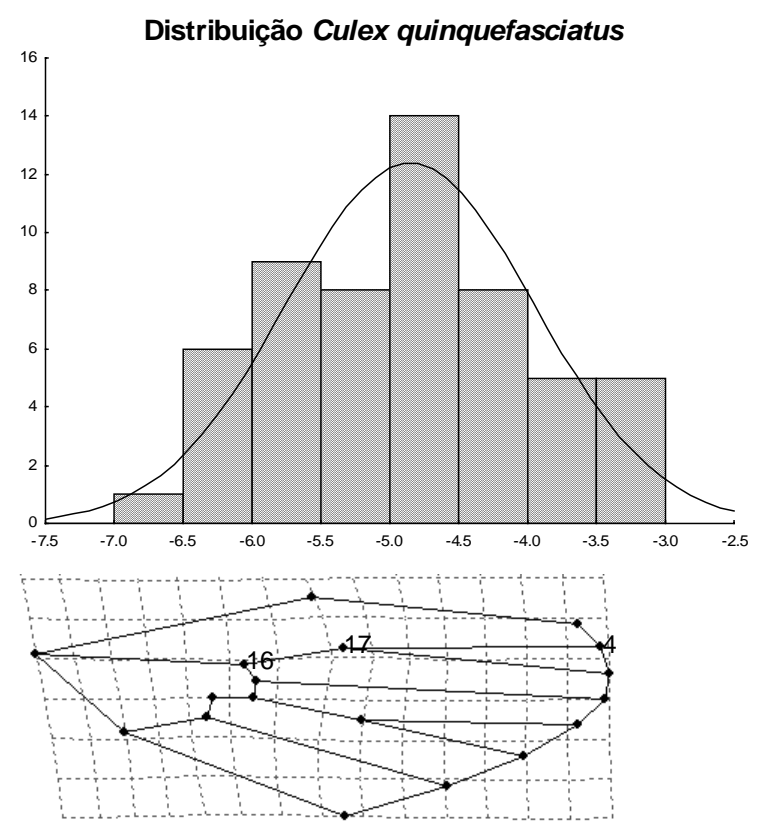

Cx. quinquefasciatus

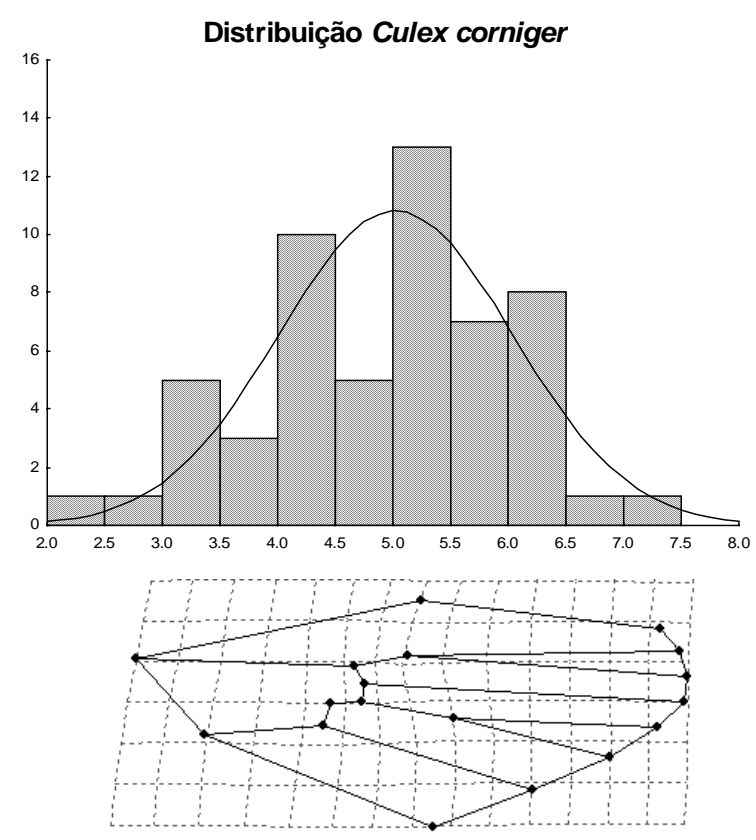

Cx. corniger

Figura 2. Histogramas de distribuição dos indivíduos ao longo da VC resultante da comparação entre fêmeas das duas espécies (valores VC no eixo X, número de indivíduos em cada categoria no eixo Y). Os valores aproximam-se da distribuição normal, conforme ilustrado pela curva Gaussiana hipotética. Notar que não há sobreposição e que a distância relativa entre os pontos 4, 16 e 17 é distintiva, mostrando que não há sobreposição entre as espécies. Abaixo, os respectivos diagramas de deformação obtidos a partir da regressão dos valores da variável canônica, sobre os componentes de forma. 
As deformações das configurações alares produzidas pela regressão dos valores da variável canônica sobre os componentes de forma (Fig. 2), indicaram as principais diferenças morfológicas alares entre as espécies. Quanto mais próximo dos extremos dos eixos das VCs está situado um indivíduo, mais semelhante àquela conformação extrema serão suas asas (Fig. 2). As maiores variações interespecíficas residiram nas posições relativas entre os pontos $4,16,17$, sendo que o ponto 17 mostrou-se o mais diagnóstico. Ao dividirmos o valor do comprimento do segmento de reta 16-17 pelo segmento 17-4, obtém-se uma razão de 4,55 para $C x$. corniger e de 2,76 para $C x$. quinquefasciatus. A razão obtida entre o segmento de reta Em suma, observando-se o ponto 17 percebe-se que a bifurcação da veia $R_{2+3}\left(e m R_{2} \mathrm{e}\right.$ $R_{3}$ ) é mais proximal em $C x$. corniger e mais distal em Cx. quinquefasciatus.

A análise de tamanho de centróide mostrou que os tamanhos de $C x$. quinquefasciatus variaram de $2,46 \mathrm{~mm}$ a $3,02 \mathrm{~mm}$, com média de $2,86 \mathrm{~mm}$ e de $C x$. corniger de $2,69 \mathrm{~mm}$ a $3,04 \mathrm{~mm}$ com média de $2,85 \mathrm{~mm}$ (Fig.3). Comparações estatísticas de indicaram que não há diferença interespecífica significativa de tamanho (teste-T, $p>0,05)$.

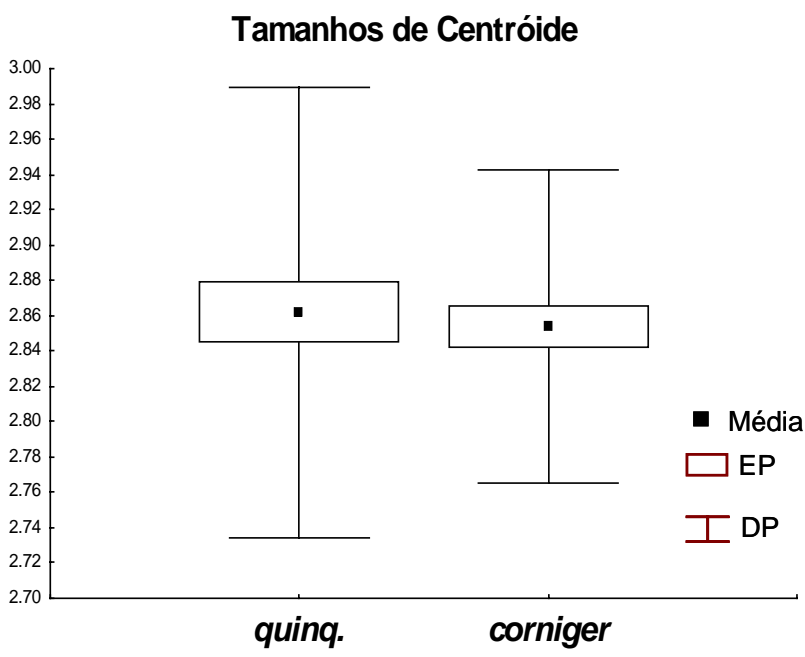

Figura 3. Gráfico ilustrando as médias de tamanho de centróide das asas de fêmeas de $C x$. quinquefasciatus e $C x$. corniger e os respectivos erros e desvios-padrão. Valores no eixo $Y$ em milímetros. As distribuições são estatisticamente semelhantes.

\section{Discussão}

A partir dos presentes resultados, pode-se interpretar que os formatos alares são distintos em $C x$. quinquefasciatus e Cx. corniger, o que facilita a identificação em situações em que apenas asas estão disponíveis. A razão entre os segmentos definidos pelos pontos 4, 16 e 17 pode ser usada como diagnóstica para essas espécies, o que vem agregar caracteres taxonômicos às suas descrições.

No geral, as descrições das duas espécies são bem detalhadas e bastante satisfatórias para amostras zoológicas em bom estado de conservação (STRICKMAN; PRATT, 1989; FORATTINI, 2002). Tentativas bem-sucedidas de diagnosticar larvas de $C x$. corniger dentre outros culicídeos urbanos que ocupam o mesmo nicho ecológico também já foram realizadas (AVENDANO-LOPEZ; CALDERON-ARGUEDAS, 2006).

Entretanto, dentro de nosso conhecimento, esta é a primeira vez em que mofometria geométrica alar é aplicada para auxiliar na diagnose desses táxons. Vale ressaltar que a presente caracterização somente é válida quando as amostras contêm apenas indivíduos de $C x$. quinquefasciatus e Cx. corniger. Tal aplicação da morfometria geométrica na definição de marcador taxonômico poderá talvez ser estendida a outras espécies.

Curiosamente, apesar da significativa diferença morfológica interespecífica, o tamanho total das asas, avaliado pelo tamanho de centróide foi semelhante entre as espécies. É possível que haja restrições evolutivas para que o tamanho das asas não varie muito, embora seu formato tenha sofrido significativas alterações ao longo do processo de especiação desses táxons. Tal hipótese poderá ser objeto de estudo futuro.

\section{Conclusão}

É possível identificar inequivocamente essas espécies apenas por caracteres alares, baseandose no seguinte fato: o ponto 17 (confluência das veias $R_{2}$ e $R_{3}$ ) é mais proximal em $C x$. corniger e mais distal em $C x$. quinquefasciatus.

\section{Agradecimentos}

Agradecemos à Prof. Dra. Maria Anice Mureb Sallum pela identificação dos espécimes coletados e à FAPESP, pelo apoio financeiro (processos 06/02622-5 e 07/01665-5).

\section{Referências}

- AVENDANO-LOPEZ, A.; CALDERONARGUEDAS, $O$. Análisis morfométrico $y$ morfológico de la larva madura de Culex (Culex) corniger (Diptera: Culicidae). Brenesia. n.65, p.5560, 2006.

- FORATTINI, O.P. Culicidologia Médica. V.2. São Paulo: Edusp, 2002. 860p. 
- FORATTINI, O.P. et al. ew findings of Anopheles mosquitoes in artificial containers. Journal of Public Health. V. 32, n. 6, p. 598-599, 1998.

- NATAL, D.; UENO, H.M.; Vírus do Nilo Ocidental: Características da Transmissão e Implicações Vetoras. Entomol. Vect. V.11, n.3, p.417-433, 2004.
- ROHLF, F.J. Geometric morphometrics simplified. Review of "Geometric Morphometrics for Biologists: a primer". Trends in Ecology and Evolution. V.20, p.3-14, 2005.

- STRICKMAN, D.; PRATT, J. Redescription of Culex corniger Theobald and elevation of $C x$. (culex) lactator Dyar and knab from synonymy based on specimens from Central America (Diptera: Culicidae). Proc. Entomol. Soc. Wash. V. 91, n.4, p. 551-574, 1989. 